\title{
Alternative Treatments for Cancer Prevention and Cure
}

\section{[Part 1]}

\section{Abdul Kader Mohiuddin*}

Secretary \& Treasurer Dr M. Nasirullah Memorial Trust, Tejgaon, Dhaka, Bangladesh

*Corresponding author: Abdul Kader Mohiuddin, Secretary \& Treasurer Dr M Nasirullah Memorial Trust, Tejgaon, Dhaka, Bangladesh, Tel: +8802-9110553; Email: trymohi@gmail.com

\section{Review Article}

Volume 4 Issue 4

Received Date: September 02, 2019

Published Date: October 17, 2019

DOI: $10.23880 /$ apct-16000168

\section{Abstract}

Many lay people along with some so called "key opinion leaders" have a common slogan "There's no answer for cancer". Again, mistake delays proper treatment and make situation worse, more often. Compliance is crucial to obtain optimal health outcomes, such as cure or improvement in QoL. Patients may delay treatment or fail to seek care because of high out-of- pocket expenditures. Despite phenomenal development, conventional therapy falls short in cancer management. There are two major hurdles in anticancer drug development: dose-limiting toxic side effects that reduce either drug effectiveness or the QoL of patients and complicated drug development processes that are costly and time consuming. Cancer patients are increasingly seeking out alternative medicine and might be reluctant to disclose its use to their oncology treatment physicians. But there is limited available information on patterns of utilization and efficacy of alternative medicine for patients with cancer. As adjuvant therapy, many traditional medicines shown efficacy against brain, head and neck, skin, breast, liver, pancreas, kidney, bladder, prostate, colon and blood cancers. The literature reviews non-pharmacological interventions used against cancer, published trials, systematic reviews and meta-analyses.

Keywords: Cancer Care; Alternative Therapy, Complimentary Medicine; Non-Pharmacological Cancer Treatment

Abbreviations: AICR: American Institute for Cancer Research; ALL: Acute Lymphoblastic Leukemia; AML: Acute Myeloid Leukemia; NRT: Nicotine Replacement Therapy; CHO: Carbohydrate; PGE2: Prostaglandin E2; NF-Kb: Nuclear Factor Kappa-Light-Chain-Enhancer of Activated B Cells; PI3K/Akt: Phosphatidylinositol 3Kinase/Protein Kinase; MAPK: Mitogen-Activated Protein Kinases; ERK1/2: Extracellular Signal-Regulated Kinases 1 and 2; LLC: Lewis Lung Carcinoma; VEGF: Vascular Endothelial Growth Factor; (MMP)-2: Matrix Metalloproteinase-2; ROS: Reactive Oxygen Species
(ROS); EMA: European Medicines Agency; AKR1B10: Aldo-Keto Reductase 1B10; NCI: National Cancer Institute; Sirna: Small Interfering RNA; Oscs: OrganoSulfur Compounds; TAM: Tumor-Associated Macrophages; NSCLC: Non-Small-Cell Lung Cancer; CHM: Chinese Herbal Medicines; Pcps: Primary Care Physicians; CBT: Cognitive Behavioral Therapy; Lmics: Low and/or Middle Income Countries; GLOBOCAN: Global Cancer Incidence, Mortality and Prevalence; CML: Chronic Myeloid Leukemia; LLS: Leukemia \& Lymphoma Society; ICD: Immunogenic Cell Death; TKI: Tyrosine Kinase Inhibitors; BTK: Bruton Tyrosine Kinase; GSK3ß: 


\section{Advances in Pharmacology and Clinical Trials}

Glycogen Synthase Kinase-3 $\beta$; Mcl-1: Myeloid Cell Leukemia-1; THP-1: Tamm-Horsfall Protein 1; Mtor: Mammalian Target of Rapamycin; SHIP2: Src-Homology 2-Containing Inositol-5-Phosphatase 2; PTEN: Phosphatase and Tensin Homolog; PHF6: Plant Homeodomain Finger 6; T-ALL: T-Cell Acute Lymphoblastic Leukemia; NQ01: NADPH Quinone Dehydrogenase 1; Nrf2: Nuclear Factor Erythroid 2Related Factor 2; Prb: Rb Tumor Suppressor Protein; JNK: C-Jun NH2-Terminal Kinase; HLA: Human Leukocyte Antigen; EGCG: Epigallocatechin Gallate; BRCA-1: Breast Cancer Gene-1; CIPN: Chemotherapy-Induced Peripheral Neuropathy; SMT: Sensorimotor Training; WBV: Whole Body Vibration; NCT: Neoadjuvant Chemotherapy; DEHP: Di(2-Ethylhexyl)Phthalate; PD-L1: Programmed DeathLigand 1; CDKN1A: Cyclin-Dependent Kinase Inhibitor 1A Gene; TFAP2A: Transcription Factor AP-2 $\alpha$; STRAP: Serine-Threonine Kinase Receptor-Associated Protein; MELK: Maternal Embryonic Leucine Zipper Kinase; CSN6: COP9 Signalosome Subunit 6; TRAIL: TNF-Related Apoptosis-Inducing Ligand; IPF: Idiopathic Pulmonary Fibrosis (IPF); GET: Graded Exercise Therapy; MLD: Manual Lymph Drainage; TENS: Transcutaneous Electrical Nerve Stimulation; AAA: Animal-Assisted Activities; MDR: Multi-Drug Resistant; MTX: Methotrexate; XIAP: X-Linked Inhibitor of Apoptosis Protein; DMH/DSS: Dimethylhydrazine /Dextran Sulphate Sodium; Ciaps: Cellular Inhibitor of Apoptosis Proteins; RXR: Retinoid X Receptor; CIPN: Chemotherapy-Induced Peripheral Neuropathy; CAM: Complementary And Alternative Medicine

\section{Introduction}

In 2019, 1.8 million new cancer cases and 0.6 cancer deaths are projected to occur in the USA [1-3]. Globally, cancer responsible for at least $20 \%$ of all mortality [4], 18.1 million new cancer (9.5 million cases were in men and 8.6 million in women, according to AICR), 9.5 million death in 2018 [5,6], 5- year prevalence 43.8 million (a nearly $67 \%$ of total cancer patients), is predicted to rise by $61.4 \%$ to 27.5 million in 2040 [7-9]. Cancer is the second most common cause of death in the USA and rest of the world $[10,11]$. It is estimated that there will be 18 million new cases of cancer and 9.6 million cancer deaths in 2018 (GLOBOCAN 2018). Mortality rates in LMICs were 2-fold higher for cervical cancer and 40\% higher for male lung and liver cancers during 2012-2016 [3], with around $70 \%$ of deaths from cancer reported in LMICs $[12,13]$. Asia, Africa, and Latin America are home of $50 \%$ of cancer patients collectively; with more than half of global cancer- associated mortalities occurring in Asia alone [13]. Lung cancer is the leading cause of cancer death (nearly 1 in 5 of all cancer death) [14], stomach cancer is the $3^{\text {rd }}$ [15] and pancreatic cancer is the $7^{\text {th }}$ [16] leading cause of cancer-related deaths worldwide. Prostate cancer is the second most frequent cancer diagnosis made in men and the fifth leading cause of cancer deaths for males [17]. Asia and Europe are the home of more than $60 \%$ prostate cancer patients [18]. Breast cancer is prevalent in $12 \%$ of women in the USA more than 2.5 million new cases of breast cancer were diagnosed in 2017 [19]. The rate for breast cancer declined by $35 \%$ in last 3 decades but number of deaths remains same [20]. The 3 most prevalent cancers in 2019 are prostate, colorectal and skin melanoma among males, and breast, uterine corpus, and colorectal among females [21]. Overall cancer death rates declined faster in blacks than whites in US, although rates for cancers of the breast, uterine corpus, and pancreas are increasing in black people [22]. Also, black men have a $70 \%$ higher prostate cancer and a more than 2 -fold higher mortality rate compared with white men [23]. The cost of delivering cancer treatment is estimated to rise globally with a projected total spending of $\$ 458$ billion by 2030 [24]. However, the financial burden stems from employment loss, cost of care even when patients don't require chemotherapy, out of pocket costs' opportunity costs of informal care time and can continue long after the death of the patient $[25,26]$. Studies say 46 billion in productivity lost in major emerging economies due to cancer [27] and economic costs of tobacco-related cancers exceed USD 200 billion each year [28]. Also, cancer causes 2.6 times more likely to file for bankruptcy than the non-cancer people [29]. Cancer trends in young adults, reflect recent changes in carcinogenic exposures, which could foreshadow the future overall disease burden [30]. Cancer cachexia (anorexia, weight loss, loss of adipose tissue and skeletal muscle) is reported in 30\%$80 \%$ cancer patients and causes $20 \%$ of all cancer deaths [31]. Worldwide, some $60 \%-80 \%$ people depend on alternative medicines [32-34], which is also true for nearly $40 \%$ to $70 \%$ European [35,36], 50\% Italian, 40\% Korean, $30 \%$ British [37] and up to $87 \%$ of Australian cancer patients [38]. Use of unapproved/unlabeled/wrong herbal treatment is not uncommon $[39,40]$ and also drug interactions reported phyto-therapeutics in oncology [41]. So, Proper and upto-date knowledge is necessary in using alternative treatment options as patients who received alternative medicines had a 2.5 greater risk of dying compared to those who received conventional cancer treatment [42] (Figure 1). 


\section{Advances in Pharmacology and Clinical Trials}

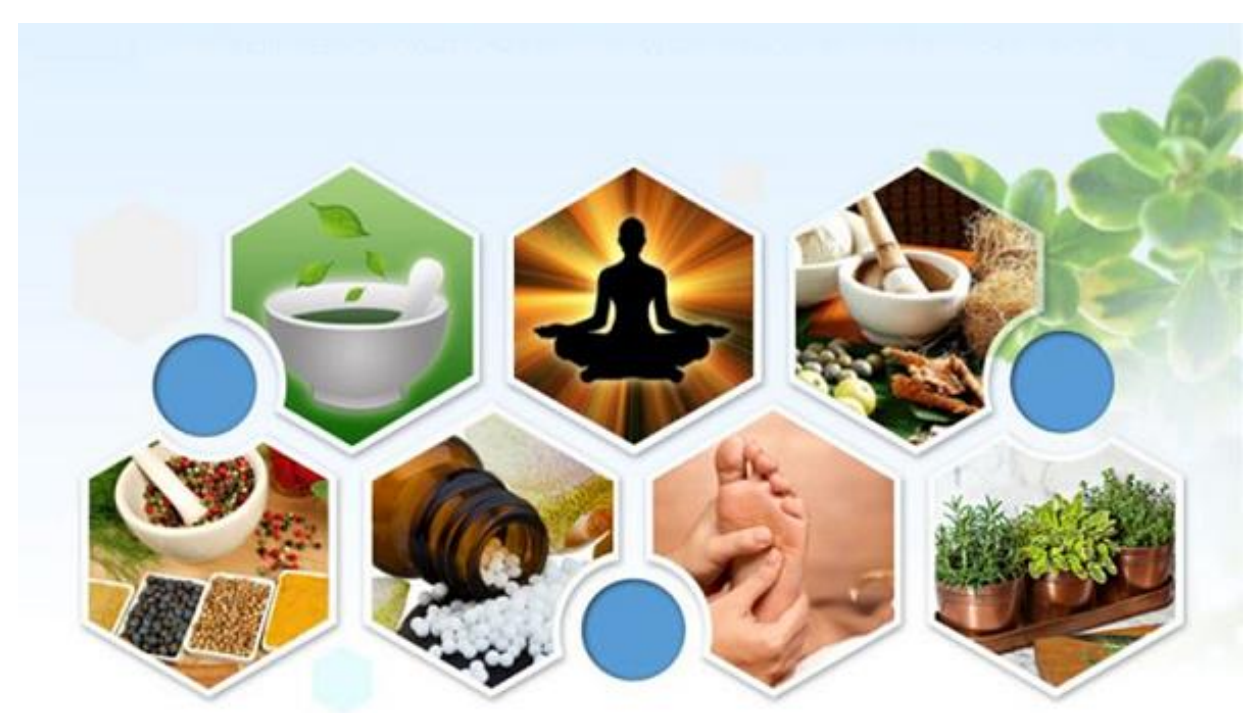

Figure 1: Alternative Treatment Options [1,2].

One third cancer patient's use alternative medicines are not well regulated and may interact with conventional treatments like chemotherapy and radiation. Some alternative therapies, like acupuncture, physical therapy, aromatherapy, CBT are widely recommended by oncologists for cancer pain management. Mind-body interventions like yoga, tai chi, meditation and mindfulness, which were each used by less than $10 \%$ of patients, can keep people fit and energetic as they undergo treatment, reduce the side effects of traditional therapies and improve patients' sleep, stress and mental health. Many hospitals even have alternative medicine centers that offer these programs.

\section{Reasons behind Choosing Alternative Care}

Pain is affects approximately $66 \%$ cancer patients [43], distressing or intolerable in more than one-third of patients [44] and chronic pain is associated with primary cancer itself or metastases or its treatment (chronic postcancer treatment pain) [43-46]. Although, WHO described opioids as essential medicines for pain control but distribution shows substantial inequity, a less than $20 \%$ of the world's population consuming more than $90 \%$ of the world's supply [46]. Also, some $85 \%$ of PCPs perceived their training in pain management to be inadequate in a Pan-European survey [47]. Along with these, fear of dependence, prescription diversion, regulatory scrutiny, withdrawal symptoms, opioid-related adverse events and deaths limit its use [46,48-52]. There is a lack of high-quality evidence regarding the analgesic efficacy of NSAIDs in cancer; contradiction and inconsistent findings also reported [53,54], although advocated as a useful adjunct for management of cancer pain $[55,56]$. In addition, long-term use of NSAIDs is often associated with many serious cardiovascular, gastrointestinal, renal, and other side effects [54,57]. Some other studies also reveal association of NSAIDs with certain cancer types $[58,59]$. Several studies support use of cannabis/marijuana in cancer pain management [6070]. Its social acceptability is gradually increasing around the world [71], but many studies oppose it's use or at least demand further investigation of benefit risk ratio [72-80]. Chemotherapy and radiotherapy are still commonly conventional approaches for treatment of patients harboring advanced cancer [81]. Traditional chemotherapy also associated with neuropathic pain [82], fatigue and sleep disturbance [83], anxiety and depression [84], mouth sores, nausea and vomiting, early satiety [85], alopecia [86], bone and muscle wasting $[31,87]$. Futile medication use in management of terminally ill cancer patients has also been reported, onefifth of cancer patients at the end of their life took futile medications (statins and antidementia drugs in nearly $100 \%$ cases, antihypertensives and bisphosphonates in nearly $30 \%$ cases) [88]. The goal of cancer palliative care is to prevent or treat, the symptoms and side effects of the cancer type and its treatment, caregiving to any related physical, emotional, social, and spiritual aspects [89-91]. Some alternative therapies, like acupuncture, physical therapy, aromatherapy, CBT are widely recommended along with mind-body interventions like yoga, tai chi, meditation and mindfulness, that keep people fit and energetic as they undergo treatment $[1,2]$. 


\section{Advances in Pharmacology and Clinical Trials}

\section{Herbal and Non-Herbal Plant Derivatives}

Medicinal plants are a rich source of secondary metabolites with interesting biological and pharmacological activities [92]. Kuruppu et.al, 2019 reported that there are 3000 plants possess some anticancer properties and nearly $75 \%$ cancer drugs are derived from natural sources, $40 \%$ of them are FDA approved [93-97]. Only a small number of natural antitumor products including vinblastine, vincristine, podophyllotoxin, paclitaxel (Taxol) and camptothecin have been tested clinically, while vinflunine ditartrate, anhydrovinblastine, NK-611, tafluposide, paclitaxel poliglumex, combretastatins, salvicine, curcumin, indirubin, triptolide, homoharringtonine are still on trial [98]. In addition, there are 195,000 pharmacologically active compounds for which the interactions are quantitatively known [99]. According to an estimate, more than 300,000 secondary metabolites exist in nature [100]. Glycosides [92], alkaloids, polyphenols, saponins, tannins and terpenoids [101] have shown promising results in cancer research. Chinese herbal medicines (CHM) also have been demonstrated to exert synergistic effects with other anticancer drugs, improved efficacy and reduced side effects [81,102-110]. It is an independent medical profession in Hong Kong and mainland China [108]. Cancer patients used CHM to improve their physical and emotional well-beings and to reduce cancer therapy-induced toxicities [111]. Nutrition and foods are related to about $30 \%$ of all the cancers cases [112]. Omega-3s from fish pack a stronger punch than other oils when it comes to cancer prevention [113-115]. Seaweeds are specifically used to treat tumors in CHM [116]. Several studies revealed that active metabolites among the terpenoids, including carotenoids, polyphenols and alkaloids that can obtained from marine source [117125]. Compounds from natural sources with antiproliferative activity represent an important and novel alternative to treat several types of cancer.

\section{Lung cancer}

American Cancer Society estimated that in 2018 lung and bronchus cancers would be responsible for 234,030 new cases which represent $14 \%$ of all new cancer cases and 154,050 deaths [126]. Non-small-cell lung cancer (NSCLC) is the most common type of lung cancer, accounting for about $80 \%-85 \%$ of all cases [127,128]. More than half of the NSCLC cases are diagnosed at an advanced stage (stages III and IV) [129]. Smoking causes at least 80\% of lung cancer deaths [130]. Lin, et al. 2019 concluded association between lung cancer incidence and increased reliance on coal for energy generation [131]. Other possible reasons are exposure to indoor and outdoor air pollution, exposure to radiation, and occupational exposure to agents such as asbestos, nickel, chromium, and arsenic [132]. Cannabidiol (a nonpsychoactive compound from Cannabis sativa), significantly inhibits the recruitment of tumor-associated macrophages (TAM) in primary tumor stroma and secondary lung metastases [133] (Table 1) (Figure 2).

\begin{tabular}{|c|c|c|c|}
\hline Plant & Plant Parts Used & Important Constituents & $\begin{array}{l}\text { Mode of Action/ Pathway Modulation/ Study } \\
\text { Results }\end{array}$ \\
\hline Allium sativum $\mathrm{L}$ & Bulbs & $\begin{array}{l}\text { Organo-sulfur compounds } \\
\text { (OSCs) like allicin (Figure } \\
\text { 2a), allixin (Figure 2b), } \\
\text { diallyl sulfide, diallyl } \\
\text { disulfide, etc. }\end{array}$ & $\begin{array}{l}\text { OSCs are antioxidant, detoxify carcinogen } \& \\
\text { have antiproliferative properties. Raw garlic } \\
\text { intake, }<2 \text { times per week, } \geq 2 \text { times per week } \\
\text { was inversely associated with lung cancer } \\
{[134-136] .}\end{array}$ \\
\hline Curcuma longa & Rhizome & Curcumin (Figure 2c) & $\begin{array}{l}\text { Inhibition of telomerase activity, dose- } \\
\text { dependent cytotoxic effect on A549 lung } \\
\text { cancer cell line [137]. }\end{array}$ \\
\hline Ferula assa-foetida & Resin & $\begin{array}{l}\text { Conferone (Figure 2d), a } \\
\text { sesquiterpene-coumarin }\end{array}$ & $\begin{array}{l}\text { Cytotoxic effect on A549 lung cancer cell line } \\
\text { [138]. }\end{array}$ \\
\hline Astragalus cytosus & Root & $\begin{array}{l}\text { Polysaccharide } \\
\text { flavonoids of } \\
\text { Astragalus spp.) }\end{array}$ & $\begin{array}{l}\text { Inhibit the proliferation and delay the tumor } \\
\text { growth xenograft of human NSCLC in vivo and } \\
\text { in vitro through the down-regulation of NF- } \\
\mathrm{\kappa B} \text { activity [139]. Astragalus polysaccharide } \\
\text { injection integrated with vinorelbine and } \\
\text { cisplatin offered an improved QOL for } \\
\text { patients with advanced NSCLC [140]. } \\
\text { Astragalus-based CHM may increase }\end{array}$ \\
\hline
\end{tabular}




\section{Advances in Pharmacology and Clinical Trials}

\begin{tabular}{|c|c|c|c|}
\hline & & & $\begin{array}{l}\text { effectiveness of } \\
\text { chemotherapy [141]. }\end{array}$ \\
\hline $\begin{array}{c}\text { Fritillariae } \\
\text { Thunbergii (Bei-Mu) } \\
\text { (Figure 3a) }\end{array}$ & Plant extract & Alkaloids & $\begin{array}{l}\text { MDR reversal activity on human lung } \\
\text { adenocarcinoma parental cells A549 with } \\
\text { dosage dependence and the apoptosis rate } \\
\text { was increased over time [142]. }\end{array}$ \\
\hline $\begin{array}{c}\text { Platycodon } \\
\text { grandiflorum } \\
\text { (Jie-Geng or balloon } \\
\text { flower) (Figure 3b) }\end{array}$ & Roots & $\begin{array}{l}\text { Platycodin D } \quad \text { (Figure } 2 \mathrm{e}) \\
\text { (Saponin) }\end{array}$ & $\begin{array}{l}\text { Blocks reduction of AKT expression by small } \\
\text { interfering RNA (siRNA) and enhance } \\
\text { apoptotic effect [143], Modulation of the } \\
\text { AMPK/mTOR/AKT, MAPK signaling pathways } \\
\text { in A549 cells [144,145], reduces the protein } \\
\text { level of PD-L1 in lung cancer cells [146] and } \\
\text { enhances autophagic cell death. }\end{array}$ \\
\hline Catharanthus roseus & $\begin{array}{c}\text { Root, stem, bark and } \\
\text { flower }\end{array}$ & $\begin{array}{l}\text { Vinca alkaloids, vinblastine, } \\
\text { vinorelbine (Figure 2f) and } \\
\text { vincristine }\end{array}$ & $\begin{array}{l}\text { Vinorelbine plus cisplatin is used for non- } \\
\text { small-cell lung cancer. vinorelbine and } \\
\text { cisplatin combination in patients with stage } \\
\text { III A and stage III B non-small-cell lung } \\
\text { exhibited positive results [147]. Resistance to } \\
\text { chemotherapy of Vinca alkaloids } \\
\text { (Microtubule-targeting agents) has been a } \\
\text { major obstacle to the treatment of lung cancer } \\
{[148] \text {. New generation agents that have the }} \\
\text { potential to overcome the mechanisms of } \\
\text { resistance to the available drugs may provide } \\
\text { new therapeutic opportunities [149]. High } \\
\text { vinorelbine blood levels were associated with } \\
\text { severe toxicity [150]. }\end{array}$ \\
\hline $\begin{array}{c}\text { Selaginella } \\
\text { tamariscina (Spike } \\
\text { Moss) (Figure 3d) }\end{array}$ & Whole plant & Amentoflavone (biflavonoid) & $\begin{array}{l}\text { S. tamariscina ethanolic extract (STE) } \\
\text { potently inhibited human AKR1B10 and } \\
\text { synergistically increased the doxorubicin } \\
\text { anti-proliferative effect in A549 and NCI- } \\
\text { H460 human lung cancer cells [151]. STE } \\
\text { decreased expressions of matrix } \\
\text { metalloproteinase (MMP)-2, -9 and urokinase } \\
\text { plasminogen activator (u-PA) reported in an } \\
\text { older study [152]. Oral administration of STE } \\
\text { could not prevent the tumor formation but } \\
\text { provided strong inhibition of tumor growth } \\
\text { [153]. }\end{array}$ \\
\hline $\begin{array}{l}\text { Crocus sativus L. } \\
\text { (Saffron) }\end{array}$ & Dried stigmas & $\begin{array}{lr}\text { Crocetin } & \text { (natural } \\
\text { apocarotenoid } & \text { dicarboxylic } \\
\text { acid) } & \end{array}$ & $\begin{array}{l}\text { In vivo protective effect [154], induction of } \\
\text { apoptosis [155], suppression of pulmonary } \\
\text { tumor promotion [156] and also } \\
\text { chemosensitizer for vincristine via p53- } \\
\text { dependent and independent pathway } \\
{[157,158] \text {. }}\end{array}$ \\
\hline $\begin{array}{l}\text { Ophiopogonis } \\
\text { Decoction } \\
\text { (Mài-Mén- Dōng- } \\
\text { Tāng) (Figure 3c) } \\
\end{array}$ & Tuber and Root & $\begin{array}{l}\text { Ginsenosides, lignans, } \\
\text { steroidal saponins, and } \\
\text { homoisoflavanones. }\end{array}$ & $\begin{array}{l}\text { Modulatory effects on apoptosis, autophagy, } \\
\text { cell cycle progression, and cell proliferation } \\
\text { [159]. }\end{array}$ \\
\hline \begin{tabular}{|c|} 
Sesbania grandiflora \\
(Humming-bird \\
tree) (Figure 3e) \\
\end{tabular} & Dried leaves & Saponosides & $\begin{array}{l}\text { Methanolic fraction of } S \text {. grandiflora exerted } \\
\text { potent antiproliferative effects in the human } \\
\text { lung cancer cell line, A549, involve a pathway }\end{array}$ \\
\hline
\end{tabular}




\section{Advances in Pharmacology and Clinical Trials}

\begin{tabular}{|c|c|c|c|}
\hline & & & $\begin{array}{l}\text { that prevents NFKB activation, induction of } \\
\text { apoptosis with high levels of ROS } \\
\text { intermediates [160]. }\end{array}$ \\
\hline Toona sinensis & Leaves & $\begin{array}{l}\text { Terpenoids, } \\
\text { phenylpropanoids, } \\
\text { acid (Figure } 2 \mathrm{~g} \text { ) and } \\
\text { flavonoids }\end{array}$ & $\begin{array}{l}\text { Inhibited H441 xenograft tumor growth in } \\
\text { vivo and in vitro, induction of apoptosis in } \\
\text { vitro [161]. }\end{array}$ \\
\hline $\begin{array}{l}\text { Phyllanthus emblica } \\
\text { and Terminalia } \\
\text { bellerica }\end{array}$ & Fruits & $\begin{array}{l}\text { Pyrogallol and gallic acid } \\
\text { (tannin) }\end{array}$ & $\begin{array}{l}\text { With doxorubicin or cisplatin resulted in a } \\
\text { synergistic effect and the possibility of } \\
\text { reducing the doses of the chemotherapeutic } \\
\text { drugs [162]. Antiproliferative and antitumor } \\
\text { properties on lung cancer cells and lung } \\
\text { adenocarcinoma xenografts due to presence } \\
\text { of tannins }(P \text {. emblica) [163]. T. belerica } \\
\text { induced apoptosis in lung cancer through } \\
\text { regulation of Bax/Bcl-2 is also reported [164]. }\end{array}$ \\
\hline $\begin{array}{l}\text { Cinnamomum } \\
\text { subavenium }\end{array}$ & Leaves and bark & Subamolide A (butanolide) & $\begin{array}{l}\text { Induced lung cancer cell death by ROS } \\
\text { generation, which triggers mitotic } \\
\text { catastrophe followed by apoptosis [165]. }\end{array}$ \\
\hline $\begin{array}{l}\text { Camellia sinensis } \\
\text { (Tea) }\end{array}$ & Leaves & Catechins (Polyphenol) & $\begin{array}{l}\text { (-)-Epigallocatechin-3-gallate (catechin), the } \\
\text { major polyphenol in green tea induces ROS } \\
\text { and oxidative DNA damages as well as } \\
\text { apoptosis in vivo and in vitro [166]. }\end{array}$ \\
\hline Panax ginseng & Roots & Saponins & $\begin{array}{l}\text { Ginsenoside Rh2 mediates changes in the } \\
\text { microRNA expression, related to } \\
\text { angiogenesis, apoptosis, chromatic } \\
\text { modification, cell proliferation and } \\
\text { differentiation. Another important } \\
\text { mechanism is the inhibition of tumor cells } \\
\text { angiogenesis that inhibits VEGF expression in } \\
\text { LLC. Rg3 has been found to be a potent } \\
\text { inhibitor of invasion of several tumor cell } \\
\text { lines H1650, H520 and H1963 in SCLC [167]. }\end{array}$ \\
\hline Taxus brevifolia & Bark & $\begin{array}{l}\text { Paclitaxel (Figure } 2 \mathrm{~h} \text { ) } \\
(\text { Taxol } ®) \text { (taxane dipertene) }\end{array}$ & $\begin{array}{l}\text { The paclitaxel-based formulation Abraxane } \AA \\
\text { is the only nanomedicine approved by EMA } \\
\text { and the FDA in combination with carboplatin } \\
\text { for the first-line treatment of advanced NSCLC } \\
\text { in adult patients who are not candidates for } \\
\text { potentially curative surgery and/or radiation } \\
\text { therapy [168]. Inhaled submicron particle } \\
\text { paclitaxel (NanoPac } \AA \text { ) demonstrated } \\
\text { substantial deposition and retention of } \\
\text { paclitaxel in sampled lung tissue in rodent } \\
\text { model [169]. }\end{array}$ \\
\hline Curcuma longa & Rhizomes & $\begin{array}{l}\text { Curcumin } \\
\text { (yellow } \\
\text { compound) }\end{array}$ & $\begin{array}{l}\text { Curcumin ( } 4 \mathrm{mg} / \mathrm{kg} \text { every } 2 \text { days for a total of } \\
7 \text { injections) exhibits a better treatment } \\
\text { efficacy of doxorubicin }(0.4 \mathrm{mg} / \mathrm{kg}) \text { in cancer } \\
\text { due to its efflux inhibitory effect of curcumin } \\
{[170] \text {. }}\end{array}$ \\
\hline
\end{tabular}

Table 1: Medicinal Plants Used in Lung Cancer. 


\section{Advances in Pharmacology and Clinical Trials}<smiles>C=CCS(=O)SC/C=C/Oc1c(C)oc(CCCCC)c(O)c1=O</smiles>

2 (a) Allicin

2 (b) Allixin<smiles>COc1cc(/C=C/C(=O)CC(=O)/C=C/c2ccc(O)c(OC)c2)ccc1O</smiles>

\section{2 (c) Curcumin}

2(d) Conferone

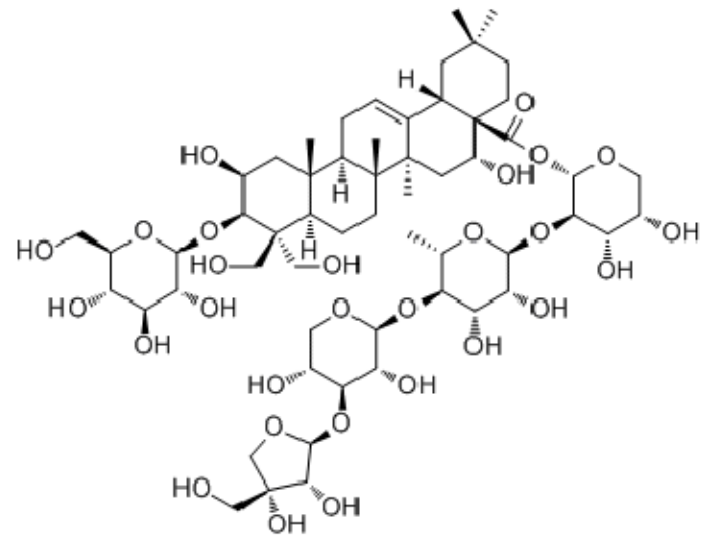

2(e) Platycodin D

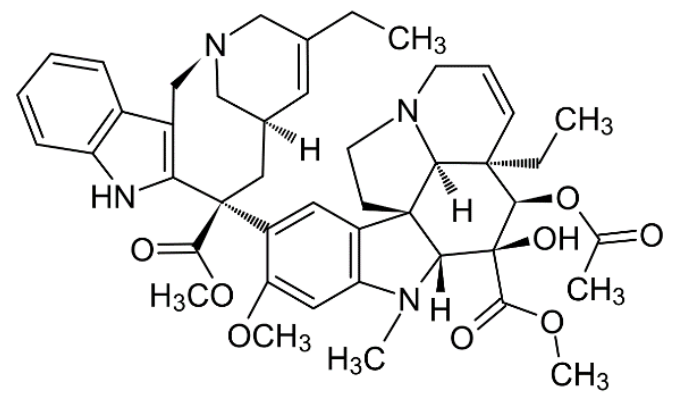

2 (f) Vinorelbine 


\section{Advances in Pharmacology and Clinical Trials}

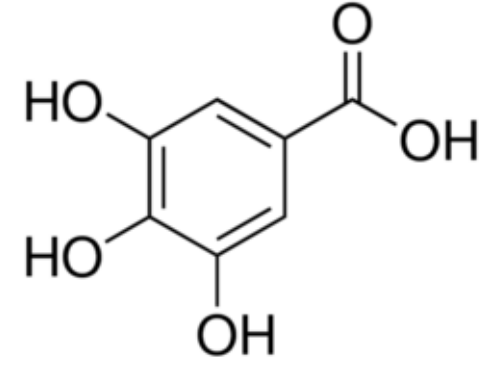

2 (g) Gallic Acid

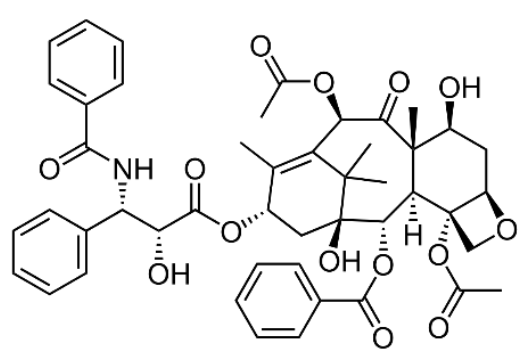

2 (h) Paclitaxel

Figure 2: Plant derived biomolecules studied in lung cancer.

Chemotherapy remains the indispensable choice for the vast majority of patients with advanced NSCLC, including primary tumors and lung metastases $[168,171]$. Use of the pulmonary route is a promising way to decrease the severe systemic toxicities associated with chemotherapy. Inhalation allows the administration of high drug doses directly to lung tumors without prior distribution in the organism $[172,173]$. However, Bei-Mu, Jie-Geng, and Mai-Men-Dong-Tang are important CHMs that have improved the survival rate [174]. Euphorbia mauritanica and Kedrostis hirtella extracts may play a role in inducing cell death in lung cancer cells [175]. Several 2019 reviews reveal fucoidans (sulfated polysaccharide mainly derived from brown seaweed) in lung cancer management. (Figure 3) Brown algae like Fucus vesiculosus, Turbinaria conoides, Laminaria japonica (Figure $3 \mathrm{~g}$ ) are reported in inhibition of tumor migration and invasion, apoptosis induction and inhibition lung cancer cell progression respectively [176]. Fucus evanescens, Sargassum sp., Saccharina Japonica was reported to inhibit proliferation and metastasis, and inducing apoptosis in vitro [177]. Undaria pinnatifida acted on ERK1/2 MAPK and p38, PI3K/Akt signaling, F. evanescens increased metastatic activity of cyclophosphamide and showed cytolytic activity of natural killer cells in 2 different studies and $F$. vesiculosus (Figure 3f) decreased NF- $\mathrm{kB}$ in LLC [178]. U. pinnatifida (Figure $3 \mathrm{~h}$ ) was found to show average antitumor and superior efficacy against LLC in review of Misra, et al. [179]. Sponge alkaloids from Aaptos showed potential in human lung adenocarcinoma A549, from Fascaplysinopsis exerted an anti-proliferative and pro-apoptotic effect in lung cancer, from blue sponge Xestospongia showed apoptosis as well as stimulate anoikis in $\mathrm{H} 460$ lung cancer cells in review by Ercolano, et al. [180]. Polyphyllin D from Paris polyphylla is well known for its induction of endoplasmic reticulum (ER) stress and mitochondriamediated apoptotic pathways against lung cancer [181]. High fish consumption was significantly associated with a decreased risk of lung cancer [182,183]. Possible mechanism could be changes in formation of PGE2 and PGE3 and alteration of Akt phosphorylation [184]. However, other studies reveal healthy dietary intake like high fruit, vegetable, soy protein, poultry (white meat), low-CHO, fish oil-containing diets, together with exercise also decline risks of lung cancer among non-smokers [185-187]. Conversely, long-term use of high doses of some supplements, such as retinol, $\beta$-carotene, B vitamins, and vitamin $\mathrm{E}$, increase lung cancer risk in current and former smokers [188]. Smokers should continue to avoid $\beta$-carotene supplementation $[189,190]$. When a person stops smoking before the age of 40, they reduce their chances of dying from smoking-related disease by $90 \%$ [191]. Telephone counseling reduces cost of nicotine replacement therapy (NRT). Again, cessation with intensive telephone counseling and NRT could be over 20\% [186]. Also, lung cancer mortality can be reduced by $20 \%$ via low dose CT lung cancer screening and treatment of early-stage disease [192]. 


\section{Advances in Pharmacology and Clinical Trials}

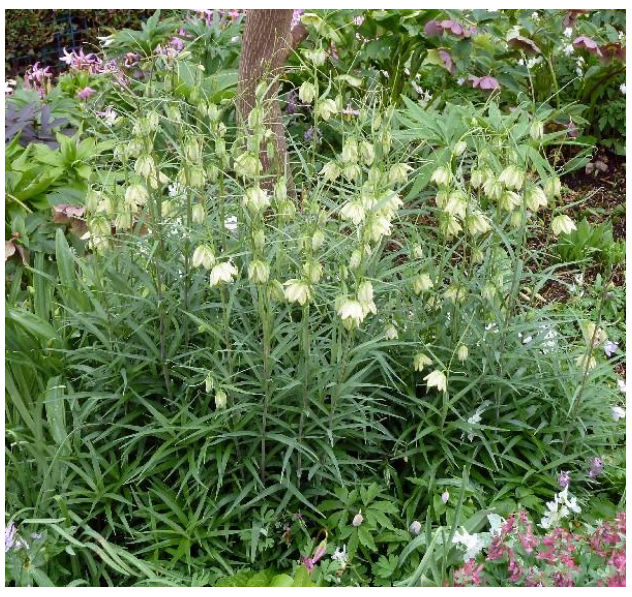

3(a) Fritillariae Thunbergii (Bei-Mu) (Source: Inner Path)

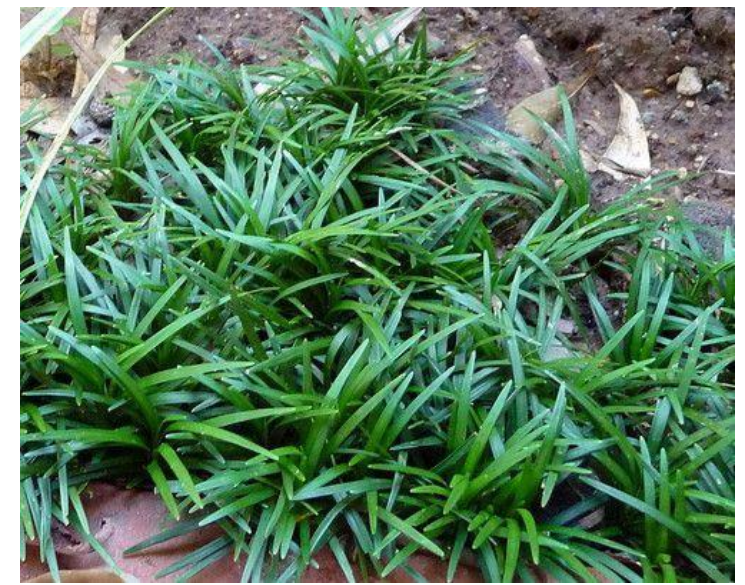

3(c) Ophiopogonis Decoction (Mài-Mén- Dōng-Tāng)

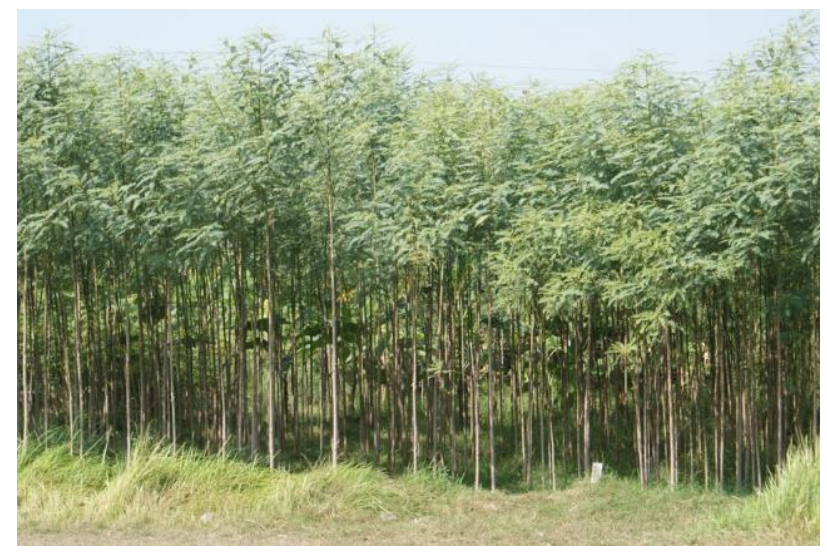

3 (e) Sesbania grandiflora (Humming-bird tree)

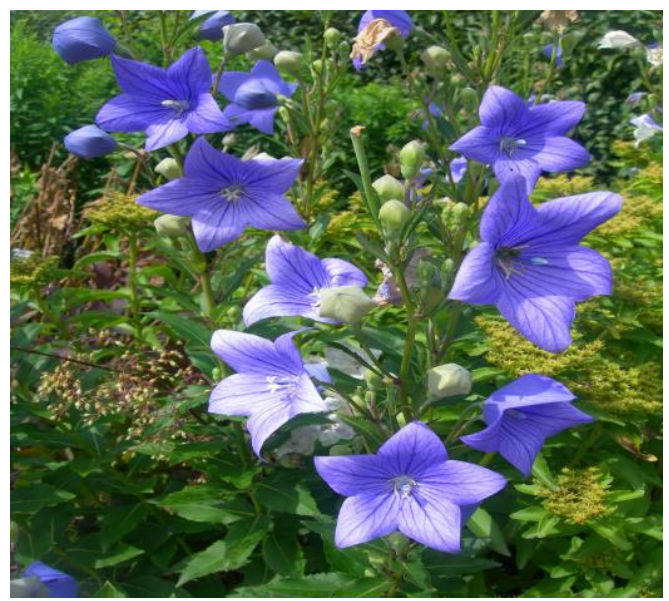

3 (b) Platycodon grandiflorum (Jie-Geng) (Source: Wikipedia)

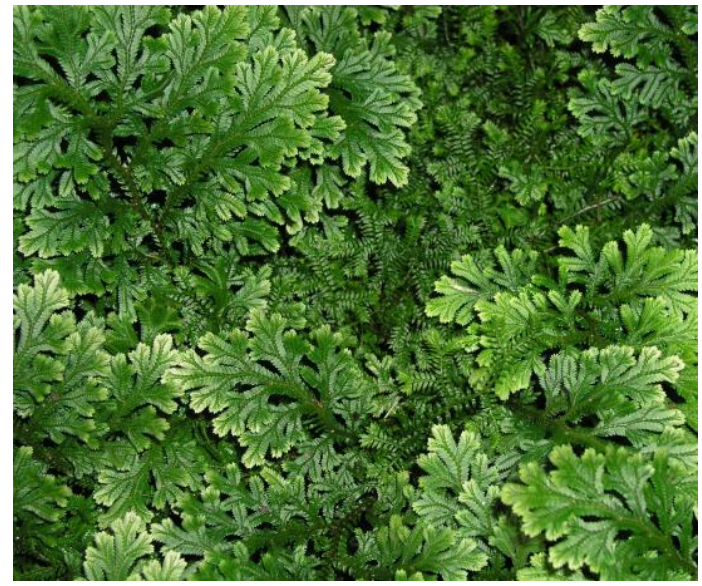

3 (d) Selaginella tamariscina (Spike Moss)

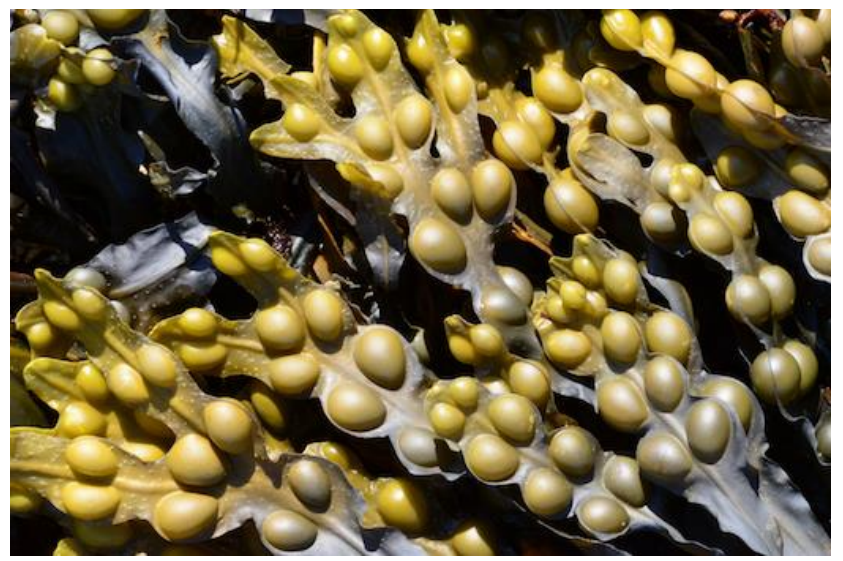

3 (f) Fucus vesiculosus L. (Source Seaweed 


\section{Advances in Pharmacology and Clinical Trials}
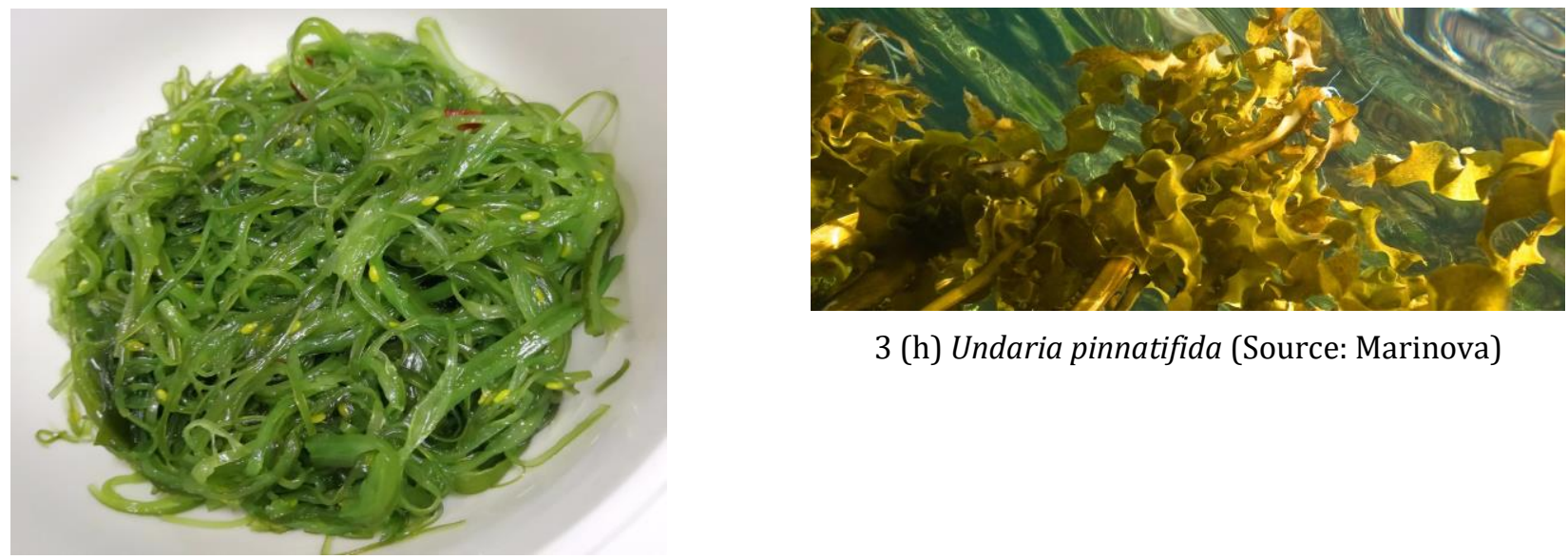

3 (h) Undaria pinnatifida (Source: Marinova)

3 (g) Laminaria japonica seaweed salad with sesame (Source: QINGDAO HILDA-JINGYI TRADING CO. LTD.)

Figure 3: Plants studied in lung cancer.

\section{Blood and Bone Marrow Cancer (Leukemia)}

Hematopoietic cancers constitute a diverse group of diseases including leukemias, lymphomas, plasma cell tumors, myelodysplastic syndromes, and mastocytosis. They arise primarily from two categories of immunological cell types, myeloid and lymphoid cells [193]. AML is the most common form of acute leukemia in adults, accounting for over $80 \%$ of all diagnosed acute leukemias [194,195]. Globally, between 1990 to 2018, the number of leukemia cases markedly increased from 297,000 to 437, 033 [196], accounting for close to 250,000 annual deaths due to AML worldwide [197].
Optimization of post-remission therapies to maintain complete remission and prevent relapse is a major challenge in treating patients with AML [198]. Children with Down syndrome have a 150 -fold increased risk of developing AML and 20-fold increased risk of developing ALL [199]. The incidence of ALL is about 3.3 cases per 100,000 children [200]. Outcomes for patients with CML have substantially improved due to advances in drug development and rational treatment intervention strategies [201]. Allowed costs for leukemia patients averaged almost $\$ 157,000$ in the year after diagnosis, with costs for AML almost tripling that amount, according to a new report from the Leukemia \& Lymphoma Society (LLS) [202] (Table 2), (Figure 4).

\begin{tabular}{|c|l|l|l|}
\hline Plant & $\begin{array}{c}\text { Plant Parts } \\
\text { Used }\end{array}$ & \multicolumn{1}{|c|}{ Important Constituents } & $\begin{array}{l}\text { Mode of Action/ Pathway Modulation/ Study } \\
\text { Results }\end{array}$ \\
\hline Zingiber officinale & Rhizome & $\begin{array}{l}\text { C-gingerol (Figure 4a), 6-shogaol } \\
\text { (Figure 4b), and 6-paradol. } \\
\text { effects on CCRF-CEM, Nalm-6 and ALL } \\
\text { primary cells [203]. [8]-shogaol, originated } \\
\text { from ginger, elevated the level of ROS, c- } \\
\text { caspase-3, -9, c-PARP, c-DFF-45, and } \\
\text { decreased the level of glutathione, MMP, } \\
\text { caspase-8 and Bid [204]. Enhanced cell } \\
\text { growth inhibition while combined with } \\
\text { Nerium oleander and imatinib [205]. }\end{array}$ \\
\hline Paris polyphylla & Tubers & $\begin{array}{l}\text { Polyphyllin D (Figure 4c) } \\
\text { (Steroids) }\end{array}$ & $\begin{array}{l}\text { Polyphyllin D induces apoptosis and } \\
\text { differentiation in K562/A02 cells through } \\
\text { G2/M phase arrest [206,207]. }\end{array}$ \\
\hline $\begin{array}{c}\text { Withania somnifera } \\
\text { (Ashwagandha/ }\end{array}$ & $\begin{array}{l}\text { Root or the } \\
\text { whole plant }\end{array}$ & $\begin{array}{l}\text { Alkaloids, flavonoids, steroids, } \\
\text { and terpenoids }\end{array}$ & $\begin{array}{l}\text { Significant cytotoxic and cytostatic potential } \\
\text { human T-lymphoblastoid cell line, and }\end{array}$ \\
\hline
\end{tabular}




\section{Advances in Pharmacology and Clinical Trials}

\begin{tabular}{|c|c|c|c|}
\hline 'Indian ginseng') & & & $\begin{array}{l}\text { induces ICD. Its proapoptotic mechanism } \\
\text { involves intracellular Ca2+ accumulation and } \\
\text { the generation of ROS [208]. Withaferin- A } \\
\text { (Withanolides, steroids) from the root } \\
\text { induced oxidative stress in human leukemia } \\
\text { HL-60 cells }[209,210] \text {. }\end{array}$ \\
\hline $\begin{array}{l}\text { Cephalotaxus } \\
\text { harringtonia } \\
\text { (Korean plum) }\end{array}$ & Leaves & 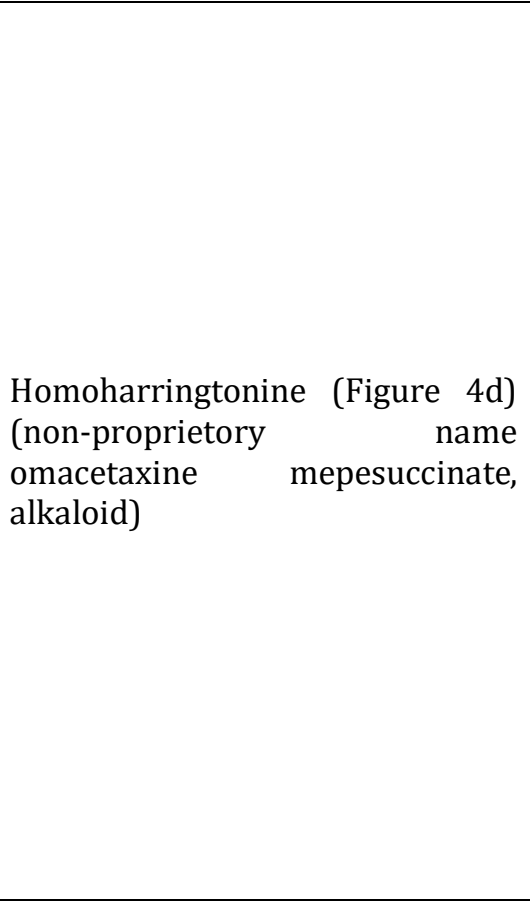 & 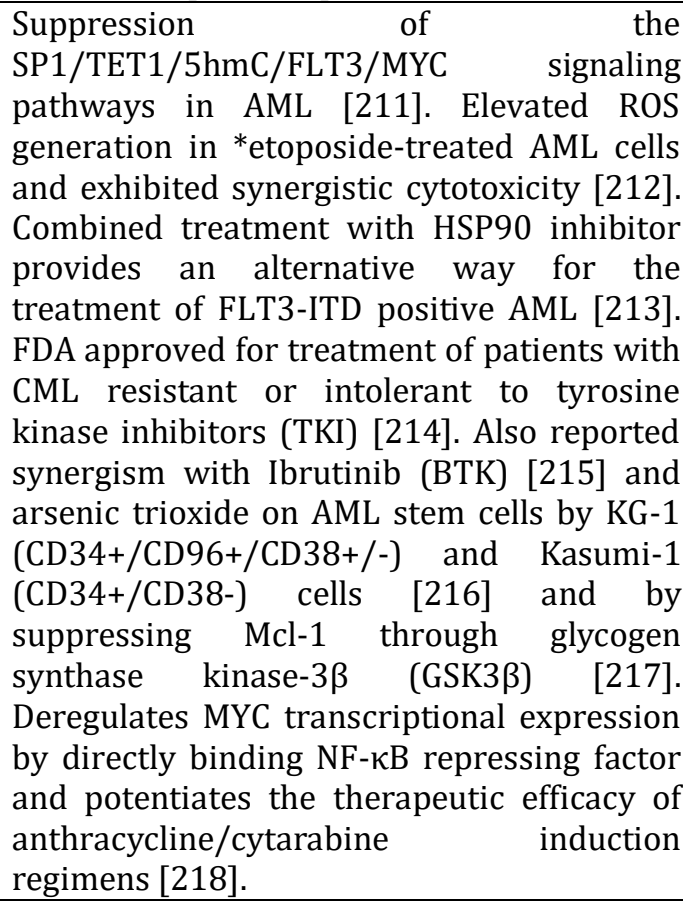 \\
\hline $\begin{array}{l}\text { Ancistrocladus } \\
\text { cochinchinensis }\end{array}$ & Leaves & $\begin{array}{l}\text { Naphthalene derivatives and } \\
\text { isoquinoline alkaloids }\end{array}$ & $\begin{array}{l}\text { Expresses cytotoxicity against HL-60 cancer } \\
\text { cells [219]. }\end{array}$ \\
\hline $\begin{array}{l}\text { Chondrodendron } \\
\text { platyphyllum }\end{array}$ & Root barks & $\begin{array}{l}\text { Curine (4e) } \\
\text { (Bisbenzyl-isoquinoline alkaloid) }\end{array}$ & $\begin{array}{l}\text { Disrupts MMP and curine presented a } \\
\text { cytotoxic effect and induced apoptosis in HL- } \\
60 \text { cells }[220] \text {. }\end{array}$ \\
\hline $\begin{array}{l}\text { Alpinia intermedia } \\
\text { (Hardy Wild Ginger) }\end{array}$ & Seeds & $\begin{array}{l}\text { Intermedin A (calcitonin family } \\
\text { peptide, labdane diterpene) }\end{array}$ & $\begin{array}{l}\text { Increases cleaved (c)-PARP and c-caspase-3 } \\
\text { levels, thus inducing apoptosis in HL-60 cells } \\
\text { at a dose of } 30 \mu \mathrm{g} / \mathrm{mL} \text { [221]. }\end{array}$ \\
\hline $\begin{array}{c}\text { Thalictrum cultratum } \\
\text { (Meadow-rue) }\end{array}$ & Root & $\begin{array}{l}\text { Thalicultratine C (Aporphinoid } \\
\text { Alkaloids) }\end{array}$ & $\begin{array}{l}\text { Downregulates MMP and induces apoptosis } \\
\text { [222] }\end{array}$ \\
\hline $\begin{array}{l}\text { Artemisia annua L. } \\
\text { (sweet wormwood) }\end{array}$ & Leaves & $\begin{array}{l}\text { Artemisinin } \quad \text { (Figure } \\
\text { (sesquiterpene lactone) }\end{array}$ & $\begin{array}{l}\text { Initiation of apoptotic cell death through } \\
\text { ROS dependent and independent } \\
\text { mechanisms, inhibition of cancer } \\
\text { proliferation, metastasis and angiogenesis, } \\
\text { and modulation of the cell signal } \\
\text { transduction pathway and cause lysosomal } \\
\text { disruption [223,224]. Combination of } \\
\text { artesunate with lenalinomide, commonly } \\
\text { used for the treatment of Multiple Myeloma } \\
\text { [225]. Hybrid } 25 \text { which proved even more } \\
\text { potent than clinically used doxorubicin } \\
\text { against CEM/ADR5000 cells [226]. } \\
\text { Significantly enhanced NK-92MI cell (natural } \\
\text { killer cells) cytotoxicity against K562 cell }\end{array}$ \\
\hline
\end{tabular}




\section{Advances in Pharmacology and Clinical Trials}

\begin{tabular}{|c|c|c|c|}
\hline & & & line [227]. \\
\hline $\begin{array}{l}\text { Clausena lansium } \\
\text { (Wampee) }\end{array}$ & Stems & $\begin{array}{l}\text { Coumarins }(8- \\
\text { geranyloxypsolaren) and 2- } \\
\text { methoxy-1-(3-methyl-buten-1- } \\
\text { yl)-9H-carbazole-3-carbaldehyde }\end{array}$ & Cytotoxicity against K562 cell line [228]. \\
\hline $\begin{array}{l}\text { Hericium erinaceus } \\
\text { (Yamabushitake, } \\
\text { mushroom) }\end{array}$ & Whole plant & polysaccharide & $\begin{array}{l}\text { Activation of mitochondria-mediated } \\
\text { caspase-3 and caspase-9, induce apoptosis } \\
\text { through down-regulation of anti-apoptotic } \\
\text { proteins (Bcl-2, Bcl-xL(S), XIAP, and cIAPs) } \\
\text { in U937 human monocytic leukemia cells } \\
\text { [229]. }\end{array}$ \\
\hline $\begin{array}{l}\text { Inonotus obliquus } \\
\text { (Chaga mushroom) }\end{array}$ & Whole plant & $\begin{array}{l}\text { Inonotodiol and inonotsuoxides } \\
\text { (lanostan-type triterpenoids) }\end{array}$ & $\begin{array}{l}\text { Inotodiol inhibits cell proliferation through } \\
\text { apoptosis induction by activating caspase- } 3 \\
\text { [230]. }\end{array}$ \\
\hline Allium sativum & Bulbs & Ajoene (Figure 4g) (OSC) & $\begin{array}{l}\text { Ajoene induced apoptosis in human } \\
\text { leukemic cells via stimulation of peroxide } \\
\text { production, activation of caspase-3-like and } \\
\text { caspase- } 8 \text { activity [122], [231]. The MAPK } \\
\text { family member ERK1/2 was also activated } \\
\text { by bisPMB (Ajoene Analogue) [232]. }\end{array}$ \\
\hline Becurinega suffruticosd & Callus & $\begin{array}{l}\text { Virosecurinine } \\
\text { (alkaloid) }\end{array}$ & $\begin{array}{l}\text { Inhibits proliferation and induce apoptosis } \\
\text { in THP-1 cells by exerting an inhibitory } \\
\text { effect on the activation of PI3K/AKT/mTOR } \\
\text { signaling pathways [233]. Inhibited the } \\
\text { growth and proliferation of the K562 cell } \\
\text { lines and induced apoptosis in K562 cells by } \\
\text { affecting the expression of mTOR, SHIP2, } \\
\text { BCR/ABL and PTEN [234]. }\end{array}$ \\
\hline Cynanchum atratum & Root & BW18 (a C-21 steroidal glycoside) & $\begin{array}{l}\text { Potential alternative for CML patients. } \\
\text { Regulating MAPK pathway leading to S phase } \\
\text { cell cycle arrest and apoptosis, inhibited cell } \\
\text { viability and proliferation of K562 cells } \\
\text { [235]. }\end{array}$ \\
\hline Curcuma longa & Rhizomes & $\begin{array}{l}\text { Curcumin } \\
\text { (yellow polyphenol compound) }\end{array}$ & $\begin{array}{l}\text { Curcumin targets multiple enzymes (eg. } \\
\text { NrF2 targeted NQ01) involved in the ROS } \\
\text { metabolic pathway to suppress tumor cell } \\
\text { growth, increases ROS levels in CML-derived } \\
\text { human leukemic cell [236-238]. Potentiates } \\
\text { the efficacy of vincristine and imatinib, } \\
\text { significantly increased the apoptosis degree, } \\
\text { decreased the activation of NF- } \kappa \text { B and the } \\
\text { expression of its regulated genes [239]. }\end{array}$ \\
\hline Camellia sinensis (Tea) & Leaves & $\begin{array}{l}\text { Epigallocatechin gallate (EGCG) } \\
\text { (Catechin) }\end{array}$ & $\begin{array}{l}\text { Inhibits growth of human myeloid leukemia } \\
\text { cells through the regulation of pRb synthesis } \\
\text { and formation of pRb-E2F complexes [240]. } \\
\text { Causes caspase-independent necrosis-like } \\
\text { cell death in CML [241]. In early-stage CLL, } \\
\text { the use of } 2 \mathrm{~g} \text { of EGCG from the green tea } \\
\text { extract twice a day was able to reduce the } \\
\text { absolute leukocyte count [242-246]. EGCG } \\
\text { was also shown to inhibit DNA replication in } \\
\text { leukemia cell lines and to modulate vascular }\end{array}$ \\
\hline
\end{tabular}




\section{Advances in Pharmacology and Clinical Trials}

\begin{tabular}{|c|c|c|c|}
\hline & & & $\begin{array}{l}\text { endothelial growth factor leading } \\
\text { apoptosis in leukemic cells }[247,248] .\end{array}$ \\
\hline $\begin{array}{l}\text { Vitis vinifera } \\
\text { (Grape) }\end{array}$ & Seed & $\begin{array}{l}\text { Proanthocyanidins, } \\
\text { (Figure 4i) (Phenols) }\end{array}$ & $\begin{array}{l}\text { Involves sustained JNK activation and } \\
\text { Cip1/p21 up-regulation, culminating in } \\
\text { caspase activation [249,250], apoptotic cell } \\
\text { death and cell growth arrest in human } \\
\text { promyelocytic leukemia HL-60 cells [251]. } \\
\text { Effective against the proliferation of both } \\
\text { types of acute leukemic lymphocytes of AML } \\
\text { and ALL patients [252]. Polydatin, a natural } \\
\text { precursor of resveratrol (RSV) induces cell } \\
\text { cycle arrest and apoptosis in MOLT-4 } \\
\text { leukemia cells [253]. Combination of } \\
\text { chloroquine with RSV and } 2 \text { other stilbenes } \\
\text { induced significant cell death and toxicity in } \\
\text { on RCH-ACV and 697 ALL cells [254]. RSV is } \\
\text { a molecule without known severe toxicities } \\
\text { [255]. Proanthocyanidin extract induced } \\
\text { mitochondria-associated apoptosis in human } \\
\text { AML 14.3D10 cells [256]. }\end{array}$ \\
\hline $\begin{array}{l}\text { Punica granatum } \\
\text { (Pomegranate) }\end{array}$ & Fruit & $\begin{array}{l}\text { Gallic acid, ellagic acid, caffeic } \\
\text { acid, chlorogenic acid, cyanidin, } \\
\text { delphinidin, pelargonidin, } \\
\text { gallotannins and ellagitannins }\end{array}$ & $\begin{array}{l}\text { Induced apoptosis and preferentially alters } \\
\text { the cell cycle in leukemia cell lines compared } \\
\text { with nontumor control cells [257]. } \\
\text { Flavonoid-rich fractions had proportional } \\
\text { inhibitory effects on HL-60 cell proliferation } \\
\text { [258]. Peel extract promotes growth } \\
\text { inhibition of K562 cells mainly via G2/M } \\
\text { phase arrest while still conserving apoptosis } \\
\text { induction, but at a lower rate [259]. Juice } \\
\text { extract significantly induced apoptosis in all } \\
\text { leukemic cell lines and also induced cell } \\
\text { cycle arrest in vitro [260]. The } \\
\text { polysaccharide PSP001, isolated from the } \\
\text { rind of pomegranate fruit exhibited anti- } \\
\text { oxidant activity in addition to growth } \\
\text { inhibitory effect on leukemic cell lines [261]. }\end{array}$ \\
\hline Panax ginseng & Root & Ginsenoside & $\begin{array}{l}\text { Ginsenoside Rh1 showed a suppressive } \\
\text { effect on the MAPK signaling pathway, } \\
\text { resulting inhibition of invasion and } \\
\text { migration of THP-1 acute monocytic cells } \\
\text { [262]. A metabolite of ginseng saponin, } \\
\text { compound K induced apoptosis in human } \\
\text { leukemia cells and also induced the } \\
\text { activation of caspase-3, -8, and -9, and } \\
\text { modulation of Bcl-2 families [263]. In } \\
\text { addition to cell growth inhibition, compound } \\
\text { K suppresses cell DNA synthesis and induces } \\
\text { cell cycle arrest at G1 phase in pediatric AML } \\
\text { [264]. It might have antileukemia activity } \\
\text { through CD11c+ cell-mediated antitumor } \\
\text { immunity [265]. Down-regulated the } \\
\text { expression of human telomerase reverse }\end{array}$ \\
\hline
\end{tabular}




\section{Advances in Pharmacology and Clinical Trials}

\begin{tabular}{|c|c|c|c|}
\hline & & & $\begin{array}{l}\text { transcriptase, with inhibiting the expression } \\
\text { of c-Myc in a concentration-dependent } \\
\text { manner [266]. }\end{array}$ \\
\hline $\begin{array}{l}\text { Podophyllum emodi } \\
\text { (Indian Origin), } \\
\text { Podophyllum peltatum } \\
\text { (American origin) }\end{array}$ & $\begin{array}{l}\text { Roots and } \\
\text { rhizomes }\end{array}$ & Podophyllotoxins & $\begin{array}{l}\text { Podophyllotoxin derivatives } \\
\text { promising cytotoxicities against a set of } \\
\text { human cancer cell lines HL-60 [267]. } \\
\text { Teniposide and etoposide have been } \\
\text { reported as inhibitors of MYB transcription } \\
\text { factor [268]. GMZ-1 suppresses growth and } \\
\text { induces apoptosis in adriamycin-resistant } \\
\text { K562/A02 cells through modulation of } \\
\text { MDR1 expression [269]. A398was cytotoxic } \\
\text { to the HT-29, MCF-7, MOLT-4 and HL-60 } \\
\text { tumor cell lines [270]. }\end{array}$ \\
\hline Coleus forskohlii & Root & Forskolin (Diterpene) & $\begin{array}{l}\text { Forskolin as a GSKJ4 sensitizer/adjuvant in } \\
\text { vivo, sensitizes Human AML Cells to } \\
\text { H3K27me } 2 / 3 \text { eemethylases GSKJ4 Inhibitor } \\
\text { via Protein Kinase A [271]. }\end{array}$ \\
\hline $\begin{array}{l}\text { Andrographis } \\
\text { paniculate } \\
\text { (Green Chirata) }\end{array}$ & Leaves & $\begin{array}{l}\text { Andrographolide } \quad \text { (Figure } 4 \mathrm{j} \text { ) } \\
\text { (Diterpene) }\end{array}$ & $\begin{array}{l}\text { Pretreatment of U937 with andrographolide } \\
\text { (AGP) followed by low doses of topotecan } \\
\text { showed an enhancement in inducing } \\
\text { apoptosis [272]. Inhibits growth of human T- } \\
\text { ALL Jurkat cells by downregulation of } \\
\text { PI3K/AKT and upregulation of p38 MAPK } \\
\text { pathways [273]. AGP was most potent to } \\
\text { induce cytotoxicity in NALM-6 cells, } \\
\text { effectively induced apoptosis by arresting } \\
\text { cell cycle progression and increased the } \\
\text { nuclear break down in NALM- } 6 \text { leukemic } \\
\text { cells [274]. Cell cycle arrest and } \\
\text { mitochondrial-mediated apoptosis in human } \\
\text { leukemic HL-60 cells also reported [275]. } \\
\text { Along with potent derivative NCTU-322, } \\
\text { downregulated Bcr-Abl against imatinib- } \\
\text { resistant CML cells [276]. Inhibits growth of } \\
\text { acute promyelocytic leukemia cells by } \\
\text { inducing retinoic acid receptor-independent } \\
\text { cell differentiation and apoptosis [277]. } \\
\text { inhibits MV4-11 cell proliferation and } \\
\text { reduces drug resistance by blocking FLT3 } \\
\text { signaling in AML [278]. }\end{array}$ \\
\hline
\end{tabular}

Table 2: Traditional Plants Used in Leukemia.<smiles>CCCCC[C@H](O)CC(=O)CCc1ccc(O)c(OC)c1</smiles>

4(a) 6-gingerol<smiles>CCCCC/C=C/C(=O)CCc1ccc(O)c(OC)c1</smiles>

4 (b) 6-shogaol 


\section{Advances in Pharmacology and Clinical Trials}

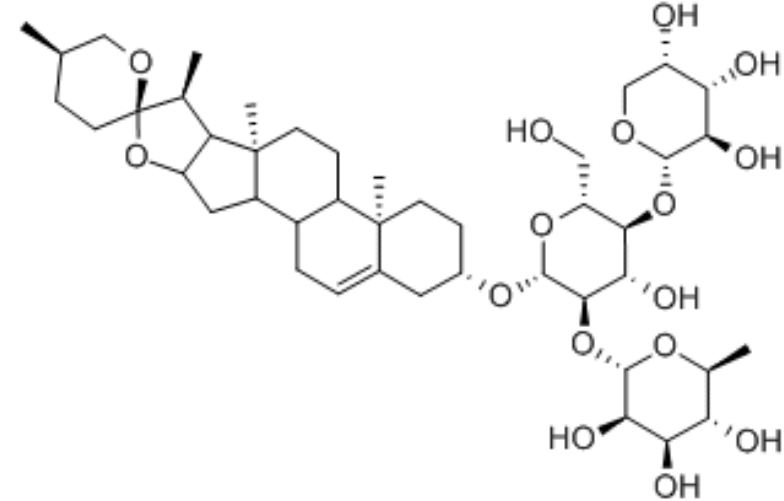

4(c) Polyphyllin D

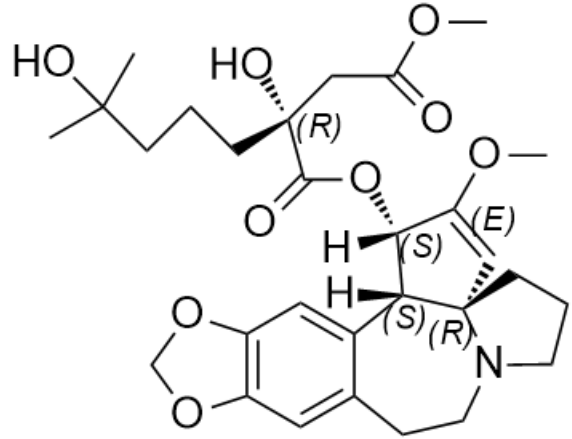

4(d) Homoharringtonine

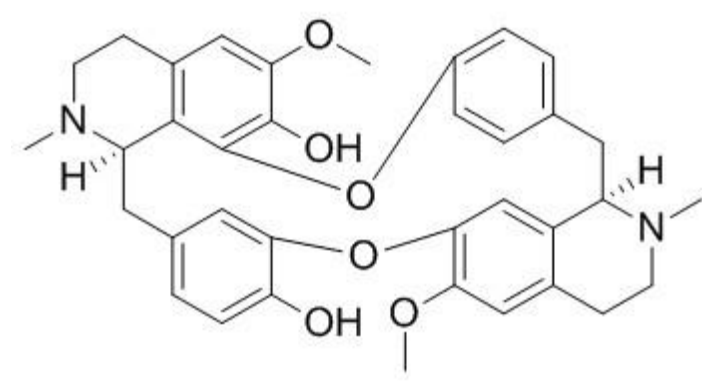

4(e) Curine<smiles>C[C@H]1CC[C@H]2[C@@H](C)C(=O)O[C@@H]3O[C@@]4(C)CC[C@@H]1[C@]32OO4</smiles>

4(f) Artemisinin

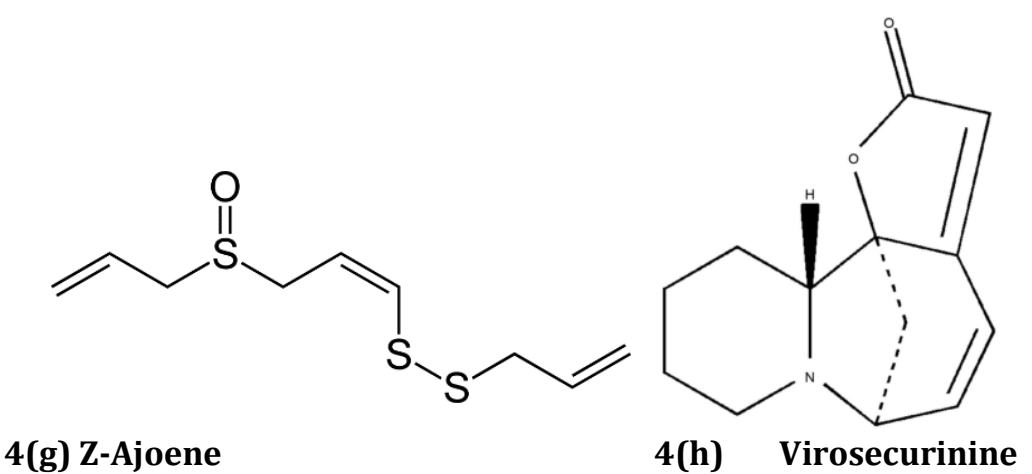

4(g) Z-Ajoene

4(h) Virosecurinine 


\section{Advances in Pharmacology and Clinical Trials}<smiles>Oc1ccc(/C=C/c2cc(O)cc(O)c2)cc1</smiles>

4 (i) Resveratrol<smiles>C=C1CC[C@]2(C(C)O)[C@@](C)(CC[C@@H](O)[C@@]2(C)CO)[C@@H]1C/C=C1\C(=O)OC[C@H]1O</smiles>

4 (j) Andrographolide<smiles>COc1cc(/C=C/c2ccc(O)cc2)cc(OCCCCCCCCCCCOc2ccccc2)c1</smiles><smiles>CC(=O)OC1CC(C)(C)[C@](O)(CC(C)=CC=CC(C)=CC=CC=C(C)C=CC=C(C)C(=O)C[C@@]2(C)C(C)CC(O)CC2(C)C)CC1C</smiles>

4(m) Fucoxanthin

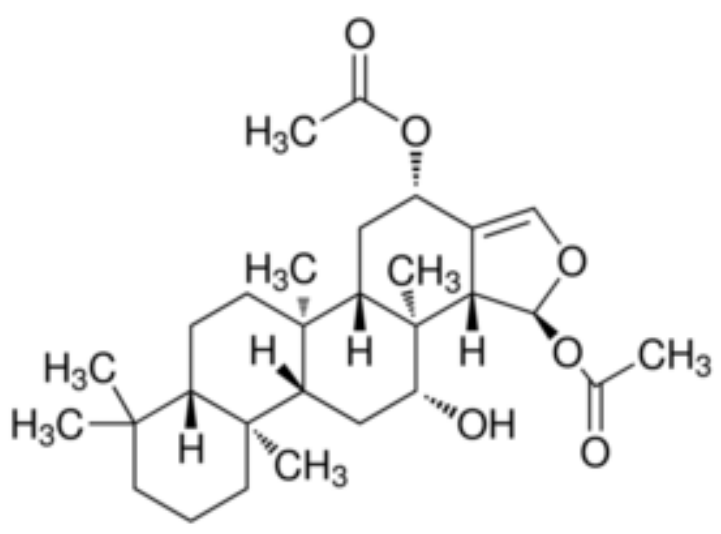

4(n) Heteronemin<smiles>COc1cc(C2c3cc4c(cc3[C@@H](O)[C@@H]3COC(=O)C23)OCO4)cc(OC)c1OC</smiles>

4(o) Podophyllotoxin

Figure 4: Plant derived biomolecules studied in leukemias. 


\section{Advances in Pharmacology and Clinical Trials}

Pterostilbene (Figure 4k) (phytoalexin) isolated from grapevine leaves and blueberries, showing no toxicity in humans up to a dose of $250 \mathrm{mg} /$ day [279], increases Fas expression in T-lymphoblastic leukemia cell lines [280]. Blueberry extracts exerted anti-AML efficacy and specifically provoked Erk and Akt regulation within the leukemia stem cell subpopulation [281]. Quercetin (Figure 4l) is a polyphenol partially responsible for the anti-AML efficacy of blueberry extracts. It can augment and focus the anti-AML efficacy of nano-liposomal ceramide (Lip-C6) and other ceramide-based therapeutics [282]. Plant Homeodomain Finger 6 (PHF6) is frequently mutated in T-cell ALL (T-ALL), or AML [283], are present in about $20 \%$ of T-ALL that causes self-renewal and hematopoietic recovery after chemotherapy [284]. PHF6 mutations have a significant role in leukemia stem cell activity in the pathogenesis of T-ALL [285]. PHF2 low expression was significantly associated with leukemia cell proliferation and several poor prognostic indicators in adult ALL patients. By restoring IKAROS function (zinc finger transcription factor encoded by the IKZF1 gene), PHF2 can be promoted through histone modification [286]. Sarkar, et.al. [287] depicted plants of West Bengal (bark of Flacourtia indica, leaves of Madhuca longifolia (Figure 5b) and Prosopis cineraria) (Figure 5c) showed better cytotoxicity in both AML and CML cell lines (HL-60 and K562). Danışman, et al. [288] reported combination of flavonoids (apigenin, luteolin, 5-desmethyl sinensetin) and imatinib mesylate were able to enhance the cytotoxic effect on K562 cells in CML. Fucoidan (complex

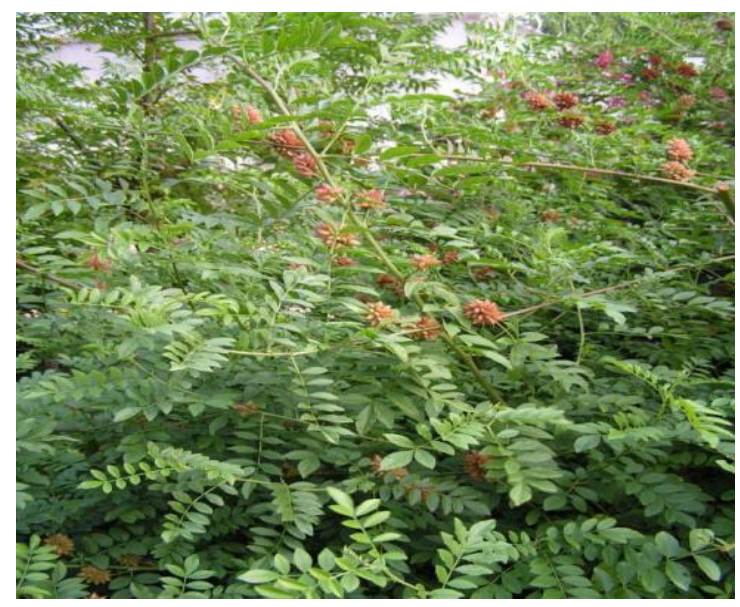

5(a) Glycyrrhiza glabra (Licorice) (Source: Onsseeds) polysaccharide from brown seaweeds) inhibited proliferation of the SKM-1 AML cell line via the activation of apoptotic pathways and production of ROS [289] and also induced apoptosis in U937 Cells through activation of p38 MAPK and modulation of Bcl-2 Family [290]. In another studies, in vitro and in vivo growth suppression [291] and enhancement of therapeutic potential of arsenic trioxide and all-trans retinoic acid [292] in acute promyelocytic leukemia cells also reported. Fucoxanthin (Figure $4 \mathrm{~m}$ ) induced apoptosis in human promyelocytic leukemia HL-60 cell [293], inhibited growth of leukemia cell lines by ROS generation [294], inhibited phosphorylation of ERK1/2 and histone H3, which are direct downstream signaling targets of lymphokineactivated killer T-cell-originated protein kinase (TOPK) [295], increased cytotoxicity against K562 cells and decreased cell proliferation of K562 and TK6 cells in vitro in imatinib and doxorubicin combination [296]. Phlorotannins (algal polyphenols) showed antiproliferative activity in vitro against human leukemia THP-1 and U-937 cells [297]. Heteronemin (Figure 4n) (a marine sesterterpenoid) effectively down-regulated cytarabine-induced activation of MAPK, AP-1, NF- $\mathrm{KB}$ and c-Myc, the down-stream targets of Ras signaling [298]. Cichorium intybus, Rheum ribes, Alhagi pseudalhagi and Glycyrrihza glabra (Figure 5a) (Iranian Traditional plants) also showed notable effects on the leukemia cell lines [299]. Juniperus sp. (Figure 5d) can be considered as an alternative source of podophyllotoxin (Figure 4o) and deoxypodophyllotoxin [300] (Figure 5).

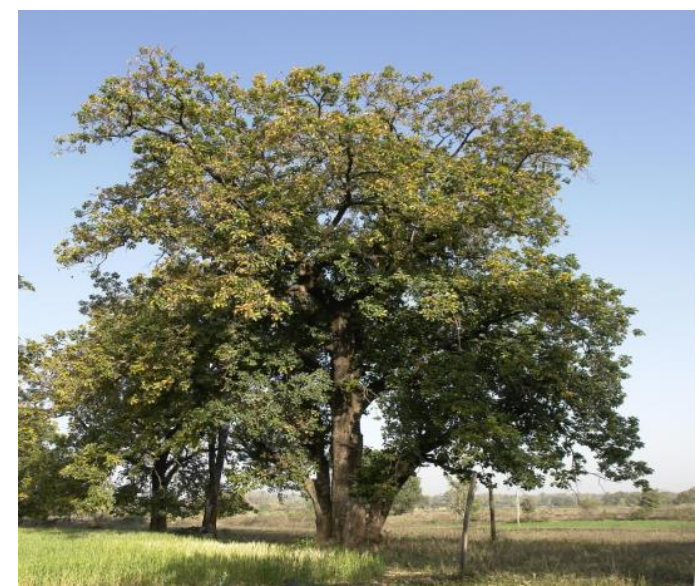

5(b) Madhuca longifolia (Mahua/Madhuca) (Source: Useful Tropical Plants - Ken Fern) 


\section{Advances in Pharmacology and Clinical Trials}

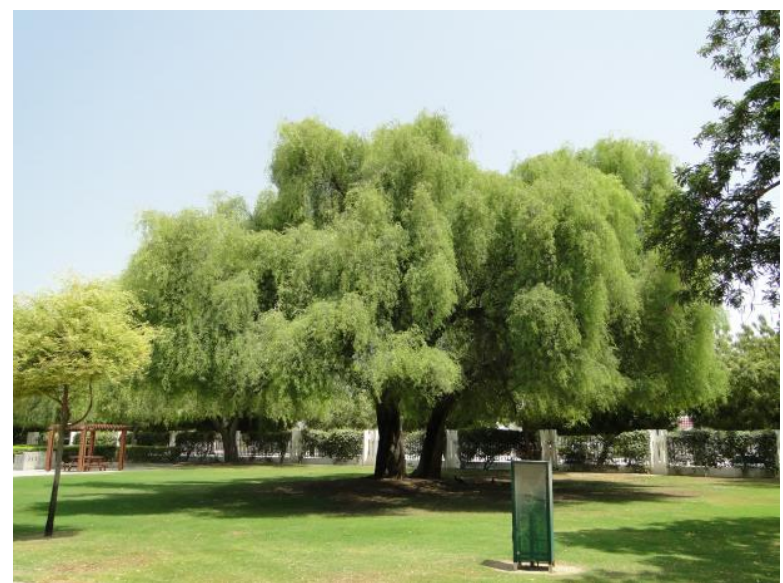

5(c) Prosopis cineraria (Khejri/Shami tree) (Source: Greensouq.ae)

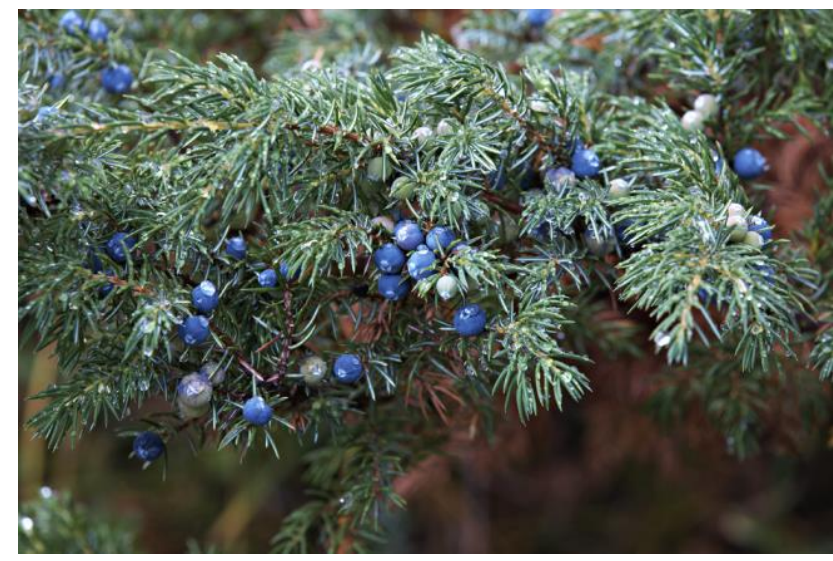

5(d) Juniperus communis (Common Juniper) (Source: IUCN Red List)

Figure 5: Plants studied in leukemias

\section{Breast Cell Carcinoma}

The most common breast cancer type is the invasive ductal carcinoma accounting for $70-80 \%$ of all breast cancers diagnosed [301]. It starts in a milk passage (a duct), breaks through the wall of the duct and invades the tissue of the breast [302]. In US, 232,000 new cases of breast cancer were diagnosed [303] and claimed the lives of 40,290 women [304] in 2015. First-degree relatives of patients with breast cancer have a 2 -fold to 3 -fold excess risk for development of the disease [305]. BRCA1 and BRCA2 are the 2 most important genes responsible for increased breast cancer susceptibility [306]. Early breast cancer detection programs depend for effectiveness on the participation rate, which is affected by risk factor awareness [307]. Since 1990, between 384,000 and 614,500 breast cancer deaths have been averted due to increased mammography screening and improved treatment [308]. However, more than 25\% breast cancer is projected to be increased by 2020 [309]. Women with breast cancer had a higher risk of developing new comorbidities than women without cancer [306]. stressful life [310], urban living, mastectomy [311], lower socioeconomic status [309,312], genetic predisposition, African-American origin, not having children or breastfeeding, early menstruation/late menopause, obesity, alcohol abuse, HRT after menopause, benign breast conditions or having breast proliferation, using contraceptives and exposure to diethylstilbestrol [313], age between 40-60, late age first pregnancy, smoking [314], abortion history [315] are the associated factors. Distressingly, the 5-year cumulative mortality remains unacceptably high at $50 \%$, primarily due to a late-stage presentation [316]. Wearing bra is not associated with breast cancer risk [317] but wearing (tight) bras for many hours and having breast implants [315], [318] may have associations. Around $60 \%$ of breast cancer mortality occurs in LMICs [319]. The prevalence cost of breast cancer care in the US in 2010 was $\$ 16.5$ billion [320,321], and exceeded $\$ 39$ billion before 2017 [322] (Table 3), (Figure 6).

\begin{tabular}{|c|l|l|l|}
\hline Plant & $\begin{array}{c}\text { Plant Parts } \\
\text { Used }\end{array}$ & \multicolumn{1}{|c|}{$\begin{array}{c}\text { Important } \\
\text { Constituents }\end{array}$} & \multicolumn{1}{|c|}{ Mode of Action/ Pathway Modulation/ Study Results } \\
\hline Podophyllum peltatum & $\begin{array}{l}\text { Etoposide (Figure } \\
\text { Roots and } \\
\text { 6e) and teniposide } \\
\text { (semisynthetic } \\
\text { derivatives of } \\
\text { podophyllotoxin) }\end{array}$ & $\begin{array}{l}\text { Target topoisomerase II and forms a complex with } \\
\text { topoisomerase II and DNA. The complex induces breaks in } \\
\text { double-stranded DNA and prevents repair by } \\
\text { topoisomerase II binding [93]. Etoposide alters the balance } \\
\text { between CDC25 splice variants in human breast cancer cell } \\
\text { lines both at the mRNA and protein levels [323]. }\end{array}$ \\
\hline Juniperus communis & Leaves & Deoxypodo- & Induced apoptosis in malignant MB231 breast cancer cells \\
\hline
\end{tabular}




\section{Advances in Pharmacology and Clinical Trials}

\begin{tabular}{|c|c|c|c|}
\hline (Juniper Berry) & & $\begin{array}{l}\text { phyllotoxin } \\
\text { (aryltetralin lignan } \\
\text { or cyclolignan) }\end{array}$ & $\begin{array}{l}\text { and inhibited MAPK/ERK and NFKB signaling pathways } \\
\text { within hours of treatment [324]. Antitumor effect of DPT on } \\
\text { MDA-MB-231 human breast cancer xenografts in vivo [325] } \\
\text { and in vitro [326]. Better efficacy to MDR breast cancer } \\
\text { than paclitaxel via avoiding efflux transport [327]. Crude } \\
\text { aqueous extract of J. communis L. significantly decreased } \\
\text { the growth of MCF-7/AZ breast cancer cells [328]. }\end{array}$ \\
\hline Catharanthus roseus & $\begin{array}{c}\text { Root, stem, } \\
\text { bark and } \\
\text { flower }\end{array}$ & $\begin{array}{l}\text { Vinorelbine, } \\
\text { vindesine, } \\
\text { vincristine and } \\
\text { vinblastine (Vinca } \\
\text { alkaloids, } \\
\text { microtubule } \\
\text { inhibitors) }\end{array}$ & $\begin{array}{l}\text { Vinca alkaloids showed Golgi-disrupting activity in } 3 \\
\text { different human breast cancer cell lines, BSY-1, MDA-MB- } \\
231 \text { and MCF-7 [329]. Possible involvement of miR-222-3p } \\
\text { expression in breast cancer cell apoptosis [330]. Quercetin } \\
\text { and vincristine are both active against ER breast cancers } \\
\text { and exhibit synergism in vitro [331]. Vinorelbine- } \\
\text { phospholipid complex reduced injection irritation and } \\
\text { maintain an antitumor effect in breast cancer in mouse } \\
\text { models [332]. }\end{array}$ \\
\hline $\begin{array}{l}\text { Taxus brevifolia and } \\
\text { Taxus baccata }\end{array}$ & Trunk bark & $\begin{array}{l}\text { Paclitaxel and } \\
\text { docetaxel } \\
\text { (Taxanes) }\end{array}$ & $\begin{array}{l}\text { Taxanes are among the most active chemotherapy agents in } \\
\text { the management of metastatic breast cancer, associated } \\
\text { less nausea and vomiting compared to non-taxane- } \\
\text { containing regimens [333,334], disrupt the equilibrium } \\
\text { between polymerized and depolymerized forms of } \\
\text { microtubules, the cellular structures required for cell } \\
\text { division [335]. Paclitaxel+ bevacizumab exhibits synergetic } \\
\text { effects and anti-tumor efficacy [336]. } \\
\text { Paclitaxel/cyclophosphamide better tolerated adjuvant } \\
\text { regimen for elderly patients than docetaxel combination in } \\
\text { elderly patients [337]. Intensive paclitaxel NCT has the } \\
\text { lowest incidence rate of neutropenia among other available } \\
\text { NCTs [338]. Docetaxel combined with trastuzumab and } \\
\text { Pertuzumab is the standard first-line therapy for HER2- } \\
\text { positive metastatic breast cancer [339], regimens } \\
\text { containing docetaxel were associated with lower CIPN } \\
\text { severity than paclitaxel [340]. Adding taxane to an } \\
\text { anthracycline-based regimen improves survival in node- } \\
\text { positive breast cancer patients [341]. } \\
\text { Taxane/cyclophosphamide was more effective than } \\
\text { taxane/anthracycline in HER2-negative, breast cancer } \\
\text { [342]. }\end{array}$ \\
\hline $\begin{array}{l}\text { Syzygium aromaticum } \\
\text { (cloves) }\end{array}$ & $\begin{array}{l}\text { Stems and } \\
\text { flowers }\end{array}$ & $\begin{array}{l}\beta \text {-caryophyllene } \\
\text { (Figure 6a) } \\
\text { (Sesquiterpene), } \\
\text { Eugenol (Essential } \\
\text { oil) }\end{array}$ & $\begin{array}{l}\text { Dried flower buds of cloves lowered VEGF-A expressions at } \\
\text { high dose and decreased MDA in vivo, induce adoptosis, } \\
\text { decrease in CD24 and EpCAM expression in mammary cells } \\
\text { [343]. } \beta \text {-caryophyllene potentiated the anticancer activity } \\
\text { of paclitaxel by facilitating the passage of paclitaxel through } \\
\text { the plasma membrane [344]. } \beta \text {-caryophyllene induced } \\
\text { ionstitutive activation of PI3K/AKT/mTOR/S6K1 signaling } \\
\text { and activation of ERK, JNK, and p38 MAPK in tumor cells } \\
\text { [345], suppressed constitutive STAT3 activation in breast } \\
\text { cancer cell lines and found cytotoxic to MDA-MB-231 [346]. } \\
\text { Eugenol inhibits the cell proliferation and induces the } \\
\text { apoptosis in human MCF-7 breast cancer cells [347]. }\end{array}$ \\
\hline Angelica archangelica & Leaves & $\begin{array}{l}\beta \text {-phellandrene } \\
\text { (Figure 6b) (cyclic }\end{array}$ & $\begin{array}{l}\text { Moderate antiproliferative activity against } \mathrm{Crl} \text { mouse } \\
\text { mammary carcinoma cells in vitro [348]. }\end{array}$ \\
\hline
\end{tabular}




\section{Advances in Pharmacology and Clinical Trials}

\begin{tabular}{|c|l|l|l|}
\hline Nigella sativa & Seed & $\begin{array}{l}\text { monoterpene) } \\
\text { Thymoquinone } \\
\text { (Figure 6c) }\end{array}$ & $\begin{array}{l}\text { Sustained inhibition of breast cancer cell proliferation with } \\
\text { long-term treatment potential [349]. }\end{array}$ \\
\hline $\begin{array}{c}\text { Viscum Album } \\
\begin{array}{c}\text { European mistletoe, a } \\
\text { hemi-parasitic shrub) }\end{array}\end{array}$ & Leaves & $\begin{array}{l}\text { Cytotoxic effect breast cancer cells (MFM-223, HCC-1937, } \\
\text { KPL-1, MCF-7) [350]. Addition to targeted therapy (with } \\
\text { mAbs, TKIs, ICIs) significantly reduced adverse effect } \\
\text { induced treatment discontinuation [351]. Devoid of herb- } \\
\text { drug interaction and interference with cytostatic effects of } \\
\text { trastuzumab on SK-BR-3 cells in vitro [352]. Decreased cell } \\
\text { proliferation, increased apoptosis and necrosis reported } \\
\text { with human ductal breast carcinoma cell line BT474 [353]. } \\
\text { An increase in the number of neutrophils and the activation } \\
\text { of the phagocytic cells also reported with V. Album [354]. } \\
\text { Apoptosis was induced by the activation of its } \\
\text { mitochondrial pathway [355]. }\end{array}$ \\
\hline $\begin{array}{c}\text { Camptotheca acuminate } \\
\text { (xí shù or happy tree) }\end{array}$ & Leaves & $\begin{array}{l}\text { Mistletoe lectin } \\
\text { (Figure 6d) } \\
\text { (Insoluble } \\
\text { pentacyclic mono- } \\
\text { terpene alkaloid) }\end{array}$ & $\begin{array}{l}\text { Low dosage camptothecin combined with oncolytic measles } \\
\text { virus found to elicit the same therapeutic effect as high } \\
\text { doses of camptothecin in breast adenocarcinoma [356]. }\end{array}$ \\
\hline
\end{tabular}

Table 3: Traditional Plants Used in Breast Cell Carcinoma

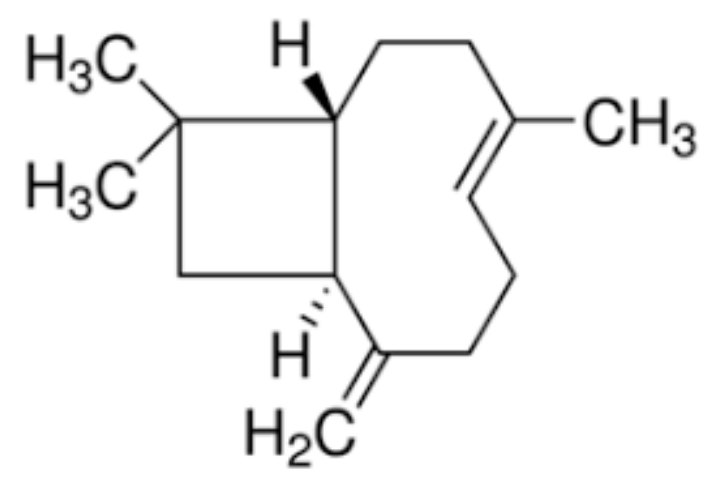

6(a) $\beta$-caryophyllene<smiles>C=C1C=CC(C(C)C)CC1</smiles>

6(b) $\beta$-phellandrene<smiles>CC1=CC(=O)C(C(C)C)=CC1=O</smiles>

6(c) Thymoquinone<smiles>CC[C@@]1(O)C(=O)OCc2c1cc1n(c2=O)Cc2cc3ccccc3nc2-1</smiles>

6(d) Camptothecin 


\section{Advances in Pharmacology and Clinical Trials}
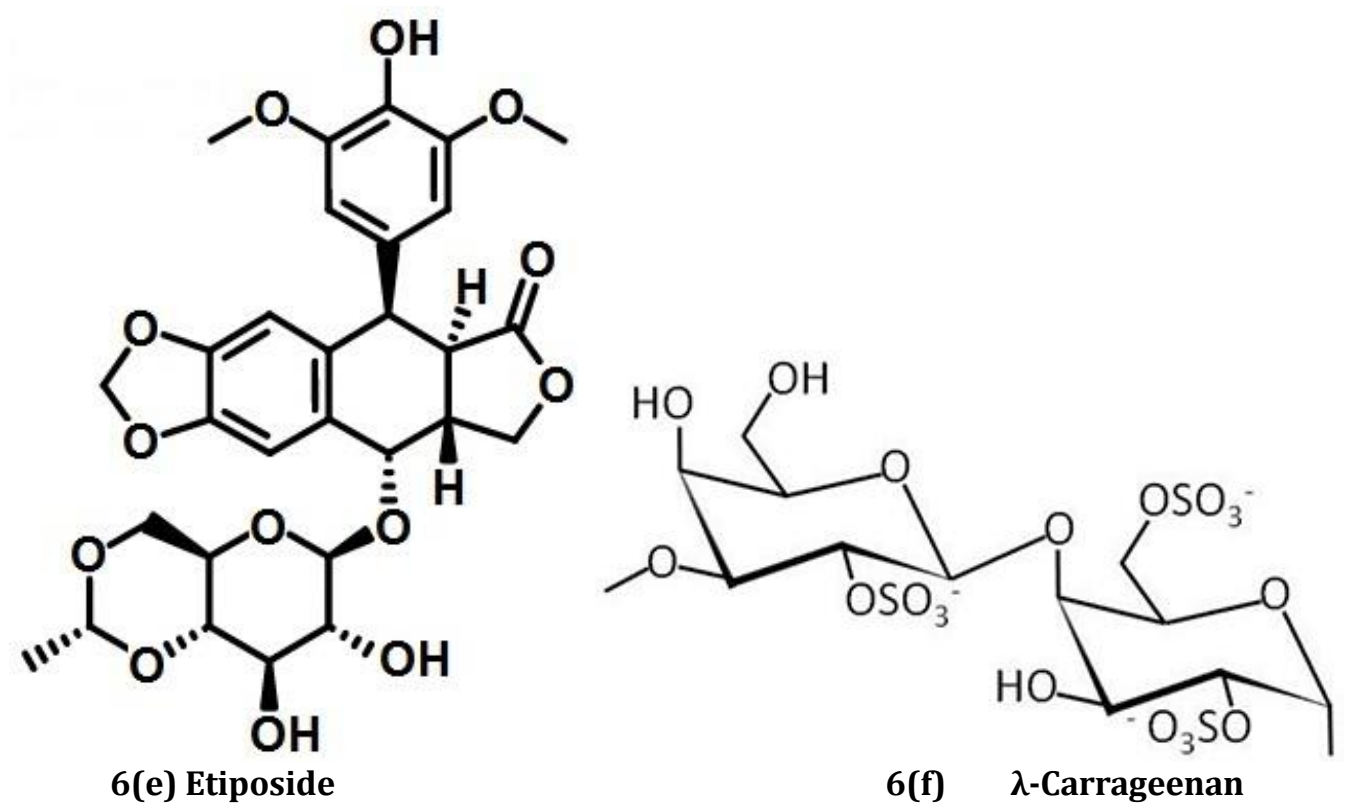

Figure 6: Plant derived biomolecules studied in breast cancer.

Ethanolic extract of Juniperus turbinate was more potent cytotoxic than cisplatin in human breast adenocarcinoma MDA-MB-231 cell lines [357]. Juniperus oxycedrus ethanolic extract from needles and berries showed potent cytotoxic effects against two breast cancer cell lines (MDA-MB-468 and MCF-7), with no cytotoxicity towards normal cells (PBMCs) [358]. Satureja khuzistanica (Figure 7a) (Lamiaceae), Casearia Sylvestris (Figure 7b) (Salicaceae), Cedrelopsis grevei (Rutaceae), Solanium spirale Roxb. (Solanaceae), carbazole alkaloids, Helichrysum gymnocephalum (Asteraceae), Pituranthos tortuosus (Apiaceae), Melaleuca armillaris (Myrtaceae), Rosmarinus officinalis (Lamiaceae), Schinus molle L. and Schinus terebinthifolius Raddi (Anacardiaceae),

Erigeron acris L. (Asteraceae), Aquilaria sinensis (Thymelaeaceae), Thymus vulgaris L. (Lamiaceae), Schefflera heptaphylla L. (Araliaceae) showed antiproliferative actions on human MCF-7 breast cancer cells [359]. XWL-1-48, a potent orally podophyllotoxin derivative suppress Topo II, induce DNA damage and apoptosis, blocks PI3K/AKT/Mdm2 pathway [360]. Alteration of Chk-2 signaling in MCF-7 cells reported with 4'-Demethyl-deoxypodophyllotoxin glucoside isolated from Podophyllum hexandrum (Figure 7c) [361]. Genistein (most abundant and active isoflavone in soy), binds to the FIH-1 binding site of HIF- $1 \alpha$ protein and downregulates HIF- $1 \alpha$ in breast cancer cell line [362]. Individuals with the habit of green tea (due to presence of EGCG) were found to have a negative association with the risk of future breast cancer (significantly increases circulating estradiol) [363-373]. Compared with the US and EU, some Asian countries like China and Japan have lower breast cancer [364], where dietary consumption of soy products is much higher than US and EU [374]. Brown seaweed fucoidan inhibited human breast cancer progression by upregulating microRNA (miR)-29c and downregulating miR-17-5p, thereby suppressing their target genes [375]. Lophocladia sp (Lophocladines), Fucus sp (fucoidan), Sargassum muticum (7f) (polyphenol), Porphyra dentata (sterol fraction), Cymopolia barbata (Figure 7e) (CYP1 inhibitors), Gracilaria termistipitata was found to be effective in breast cancer studies [376]. High Urokinasetype plasminogen activator receptor (UPAR) expression predicts for more aggressive disease in several cancer types [377], dietary seaweed may help lowering breast cancer incidence by diminishing levels of uPAR [378]. The tropical edible red seaweed Eucheuma cottonii L. (Figure $7 d$ ) is rich in polyphenols that exhibited strong anticancer effect with enzyme modulating properties [379]. Jazzara, et al. [380] concluded that $\lambda$-carrageenan (Figure 6f) (sulfated galactans found in certain red seaweeds) could be a promising bioactive polymer, showed a remarkable inhibitory effect on MDA-MB-231(triple negative breast cancer cell line) cell migration [381]. Several studies support polyphenols [382-386], flavonoids [387-395], fucoidan [396-407], lutein/zeaxanthin [408-412], other seaweed alkaloids, peptides, tannins and polysaccharides [413-425] in breast cancer management (Figure 7). 


\section{Advances in Pharmacology and Clinical Trials}

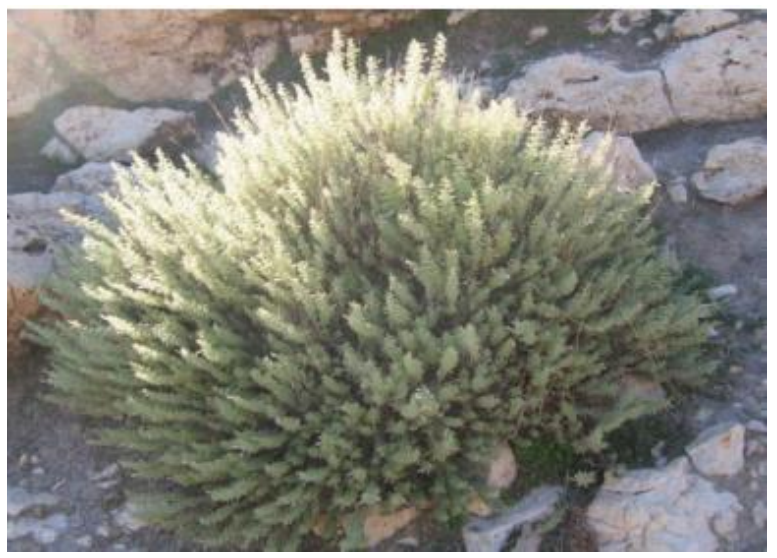

7(a) Satureja khuzistanica (Source: Med P Group)

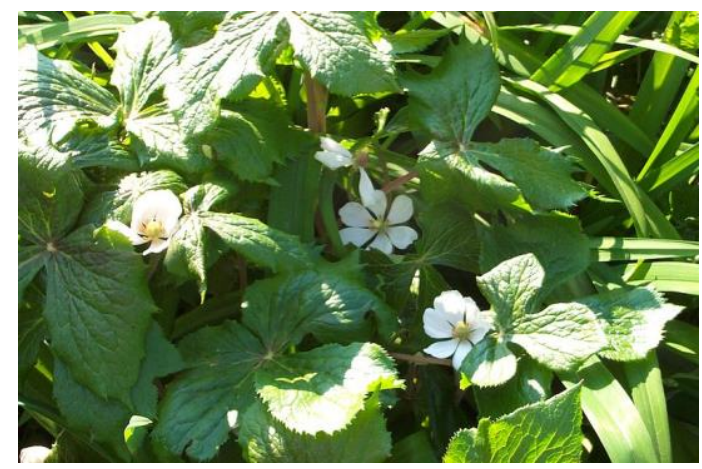

7(c) Podophyllum hexandrum (Source: Wikimedia Commons)

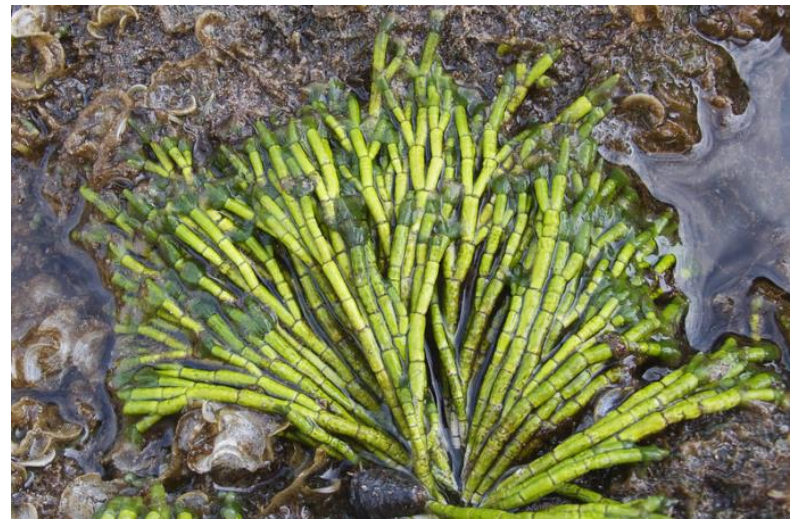

7(e) Cymopolia barbata (Source: Melev's Reef)

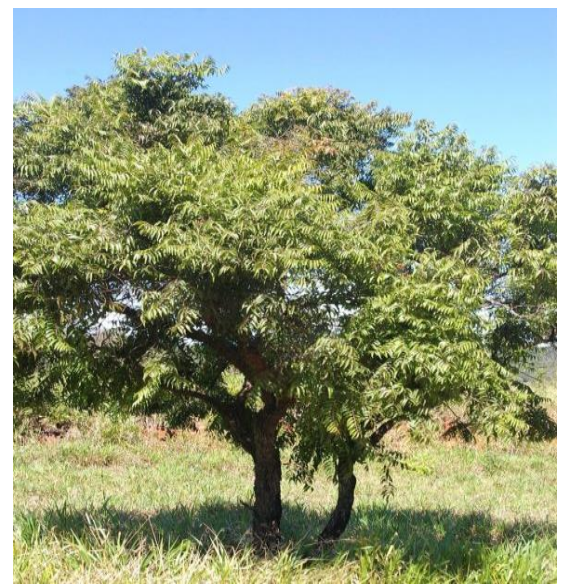

7(b) Casearia Sylvestris (Source: Árvores do Bioma Cerrado)

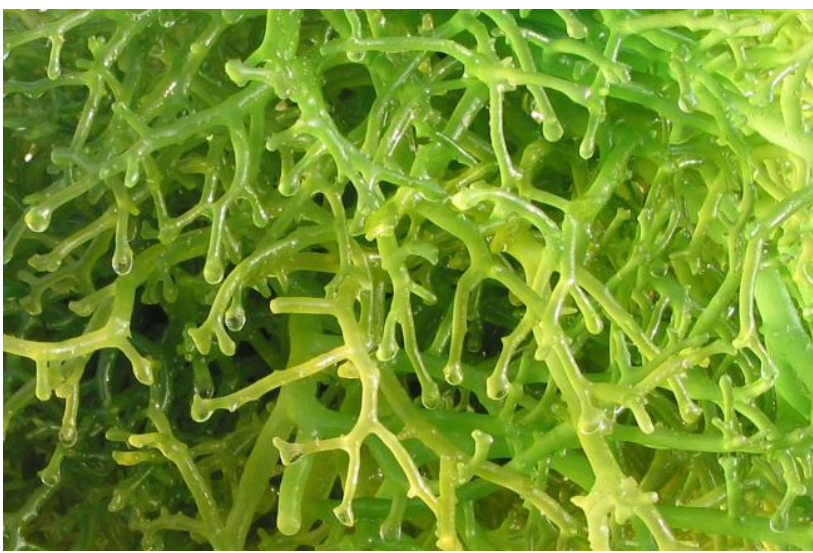

7(d) Eucheuma cottonii (Source: tradekey.com)

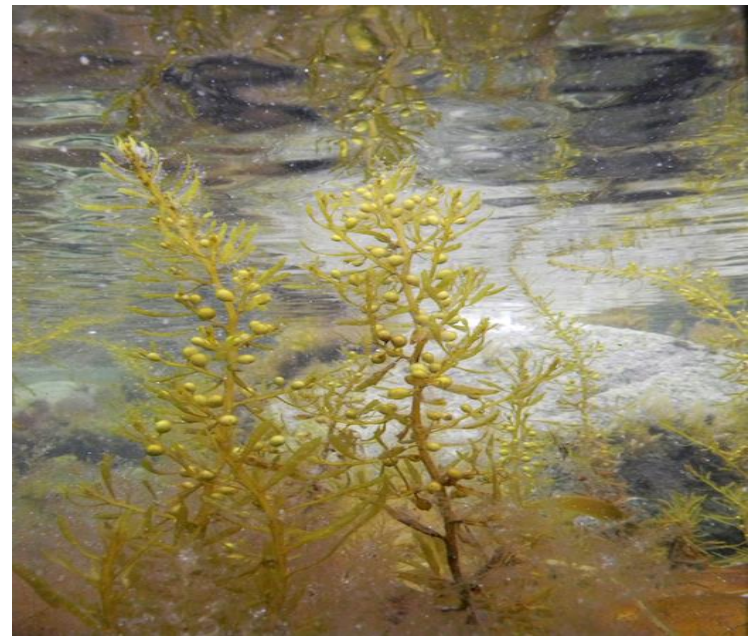

7(f) Sargassum muticum (Source: Seaweed.ie)

Figure 7: Plants studied in breast cancer 


\section{Advances in Pharmacology and Clinical Trials}

\section{Colorectal Cancer}

Colorectal cancer (CRC) is the third most common cancer worldwide and the fourth most common cause of cancer death [426]. It is the second leading cause of death in US, affecting some 135,000 estimated new patients with more than 50000 deaths every year [427-429]. In 2015 , there were 376,000 new cases and 191,000 deaths in China [430]. The overall incidence of CRC is decreasing in many high-income countries, although reported significant increase in Denmark, New Zealand, Australia, UK and Canada, mainly driven by increases in distal (left) tumors of the colon and predominant in [431-438]. Lifestyle determines around $50 \%$ to $60 \%$ incident of CRC irrespective of age [439-442]. Physical activity may prevent approximately $15 \%$ of the colon cancers [443]. Fish, poultry, cheese, fruit, vegetables, tea and coffee were not associated with colorectal-cancer risk [444]. Alcohol consumption, red meat/processed meat, junk food, smoking, diabetes and obesity potentiate the same risk [445-448]. In 2018, the estimated national expenditure was $\$ 16.6$ billion in US, which was $\$ 4.5$ billion to $\$ 9.6$ billion in 2009 and projected to be more than $\$ 20$ in 2020 [449-451]. There were over 1.8 million new cases in 2018. Hungary, North Korea, Slovakia, Norway, Denmark, Portugal, Japan are in the top-ranking positions [452]. 5year survival for patients with stage IV CRC is less than $10 \%$ [453]. The overall risk of CRC among patients with ulcerative colitis is about ten times higher than that of the general population [454]. A recent study reveals that chili peppers does not increase or decrease the risk of CRC [455]. Previous studies say capsaicin has both carcinogenic and anticancer effects (Table 4) (Figure 8).

\begin{tabular}{|c|c|c|c|}
\hline Plant & $\begin{array}{l}\text { Plant Parts } \\
\text { Used }\end{array}$ & Important Constituents & Mode of Action/ Pathway Modulation/ Study Results \\
\hline Inula Viscosa & Leaves & $\begin{array}{lr}\text { Polyphenols } & \\
\text { (caffeoylquinic acid } \\
\text { (Figure } & 8 \mathrm{a} \text { ), } \\
\text { dicaffeoylquinic } & \text { acid, } \\
\text { flavonoids, terpens, } \\
\text { lactones) } & \text { and } \\
\text { sesquiterpens } & \\
\text { (Tomentosin } & \text { and } \\
\text { Inuvisocolide) } & \\
\end{array}$ & $\begin{array}{l}\text { Affects the cell cycle progression and induces apoptosis } \\
\text { by activation of caspases in colon cancer cells. Moreover, } \\
\text { IV extract exhibits anti-tumor activities in an animal } \\
\text { model, and it is safe for use [456]. }\end{array}$ \\
\hline $\begin{array}{l}\text { Matricaria } \\
\text { chamomilla }\end{array}$ & Flowers & Flavonoids & $\begin{array}{l}\text { Apigenin ( } 4^{\prime}, 5,7 \text {-trihydroxyflavone) suppressed the EMT, } \\
\text { migration, and invasion of human colon cancer by } \\
\text { inhibiting the NF- } \mathrm{B} / \text { Snail pathway [457]. }\end{array}$ \\
\hline Curcuma longa & Rhizome & Curcumin & $\begin{array}{l}\text { Inhibit activation of NF- } \mathrm{BB} \text {, downregulates anti- } \\
\text { apoptotic, cell-proliferative, invasive, and angiogenic } \\
\text { gene products, suppress activation of STAT3, HIF-1, } \\
\text { PPAR and expression of TNF, IL-1, IL-6 [458]. }\end{array}$ \\
\hline Zingiber officinale & Rhizome & $\begin{array}{l}\text { [6]-gingerol and [6]- } \\
\text { paradol, shogaols and } \\
\text { zingerone }\end{array}$ & $\begin{array}{l}\text { [6]-gingerol, regulate the molecules in cellular signal } \\
\text { transduction pathways, including NF- } \mathrm{B} \text {, AP-1, growth } \\
\text { factors, chemokines, MAPK, p53, cyclin D1, VEGF, COX-2 } \\
\text { and iNOS pathways. [6]-gingerol and [6]-paradol have } \\
\text { been found to induce cancer cell apoptosis [458]. }\end{array}$ \\
\hline Alpinia galanga & Rhizome & $\begin{array}{l}1^{\prime} \text {-Acetoxychavicol } \\
\text { acetate (ACA) (Figure } \\
\text { 8b) }\end{array}$ & $\begin{array}{l}\text { ACA has been shown to induce apoptosis in CRC cell } \\
\text { lines, inhibits DNA synthesis, thereby inhibiting cell } \\
\text { proliferation. In rat intestine epithelial cells (IEC6), ACA } \\
\text { induced glutathione S-transferase and NAD (P)H: } \\
\text { quinone oxidoreductase } 1 \text { (NQO1) activities, increased } \\
\text { intracellular glutathione levels, and upregulated } \\
\text { intranuclear Nrf2 and cytosolic p21. It also has the } \\
\text { ability to inhibit azoxymethane-induced colon } \\
\text { tumorigenesis in rats [458]. }\end{array}$ \\
\hline $\begin{array}{l}\text { Piper longum } \\
\text { (Long pepper or }\end{array}$ & Dried fruit & $\begin{array}{l}\text { Piperlongumine (Figure } \\
\text { 8c) }\end{array}$ & $\begin{array}{l}\text { Piperlongumine targets Ras/PI3K/Akt/mTOR signaling } \\
\text { axis to inhibit tumor cell growth and proliferation in }\end{array}$ \\
\hline
\end{tabular}




\section{Advances in Pharmacology and Clinical Trials}

\begin{tabular}{|c|c|c|c|}
\hline pipli) & & & DMH/DSS induced experimental colon cancer [459]. \\
\hline $\begin{array}{l}\text { Rhizoma coptidis } \\
\text { (Huang Lian) }\end{array}$ & Rhizome & Berberine (Figure 8d) & $\begin{array}{l}\text { Downregulates } \beta \text {-catenin-induced proliferation by } \\
\text { binding RXR, cell proliferation by inducing the G2/M } \\
\text { phase arrest and down-regulated the expression of the } \\
\text { related cyclins [460]. Promotes apoptosis of CRC via } \\
\text { regulation of the long non-coding RNA (lncRNA) cancer } \\
\text { susceptibility candidate } 2 \text { (CASC2)/AU-binding factor } 1 \\
\text { (AUF1)/B-Cell CLL/Lymphoma 2 (Bcl-2) axis [461]. }\end{array}$ \\
\hline $\begin{array}{l}\text { Punica granatum } \\
\text { (Pomegranate) }\end{array}$ & Fruit & $\begin{array}{l}\text { Ellagitannins, ellagic } \\
\text { acid }\end{array}$ & $\begin{array}{l}\text { CDKN1A (p21, Cip1) induction followed by cell-unique } \\
\text { downregulation of miR-224 or upregulation of miR-215 } \\
\text { [462]. Pomegranate ellagic acid and their microbiota } \\
\text { metabolites urolithins exert anticancer effects in } \\
\text { preclinical CRC models, and target normal and malignant } \\
\text { colon tissues in CRC patients [463]. Consumption of the } \\
\text { pomegranate extract was significantly associated with a } \\
\text { counterbalance effect in the expression of CD44, } \\
\text { CTNNB1, CDKN1A, EGFR and TYMs [464]. }\end{array}$ \\
\hline $\begin{array}{l}\text { Phaseolus vulgaris } \\
\text { (Navy bean) }\end{array}$ & Beans & $\begin{array}{l}\text { Anacardic acid (Figure } \\
8 \mathrm{e} \text { ) and nobiletin }\end{array}$ & $\begin{array}{l}\text { Imparts glutathione regulation, and involved cancer } \\
\text { control mechanisms such as detoxification of } \\
\text { xenobiotics, antioxidant defense, proliferation, and } \\
\text { apoptosis. Metabolic pathways involving lysine, and } \\
\text { phytochemicals were also modulated by navy bean } \\
\text { intake in CRC survivors [465]. Anacardic acid efficiently } \\
\text { repressed expression of CD44 and MMP14 in HCT116 } \\
\text { colon cancer cells, with repression of the SUMO- } \\
\text { conjugated TFAP2A isoform and elimination of } \\
\text { CD44+/hi/ALDH+/hi cells [466]. }\end{array}$ \\
\hline Macleaya cordata & Leaves & Sanguinarine (8f) & $\begin{array}{l}\text { Sanguinarine decreased the tumor size in a dose- } \\
\text { dependent manner in orthotopical colorectal carcinomas } \\
\text { through intrinsic apoptosis pathway in BALB/c-nu mice. } \\
\text { It dephosphorelates STRAP and MELK and disassociates } \\
\text { the interaction between them to trigger intrinsic } \\
\text { apoptosis. Overexpression of STRAP and MELK may be } \\
\text { markers of CRC and their disassociation may be a } \\
\text { determinant of therapeutic efficacy [467]. }\end{array}$ \\
\hline $\begin{array}{l}\text { Betula alba (white } \\
\text { birch) }\end{array}$ & Bark & $\begin{array}{l}\text { Betulinic } \\
\text { (Pentacyclic } \\
\text { triterpenoid) }\end{array}$ & $\begin{array}{l}\text { Significantly reduced the expression of matrix } \\
\text { metalloproteinase (MMPs) and increased the expression } \\
\text { of MMPs inhibitor (TIMP-2), MMP-2+ cells and Ki-67+ } \\
\text { cells were reduced and cleaved caspase-3+ cells were } \\
\text { increased in tumor tissues of mice. Betulinic acid } \\
\text { promoted the apoptosis of CRC cells and also inhibited } \\
\text { the metastasis of cancer cells [468]. Nano-capsulated } \\
\text { analogue (2c) with better therapeutic efficacy than } \\
\text { parent molecule to colon carcinoma cells has been } \\
\text { reported [469]. }\end{array}$ \\
\hline Boswellia serrata & $\begin{array}{l}\text { Oleo-gum- } \\
\text { resin }\end{array}$ & $\begin{array}{l}3 \text { acetyl-11-keto- } \beta \text { - } \\
\text { boswellic acid (AKBA) }\end{array}$ & $\begin{array}{l}\text { AKBA induced upregulation of tumor-suppressive miR- } \\
34 \text { a and downregulation of miR-27a in CRC cells, } \\
\text { inhibited cellular proliferation, induced apoptosis and } \\
\text { cell-cycle arrest in CRC cell lines, and these effects were } \\
\text { significantly enhanced with combined treatment of } \\
\text { AKBA and curcumin [470]. }\end{array}$ \\
\hline Toxicodendron & Stokes & $\left(3,4,2^{\prime}, 4^{\prime}-\right.$ & The depletion of securing (onchoprotein) enhances \\
\hline
\end{tabular}




\section{Advances in Pharmacology and Clinical Trials}

\begin{tabular}{|c|c|c|c|}
\hline $\begin{array}{c}\text { vernicifluum } \\
\text { (formerly known as } \\
\text { Rhus verniciflua) }\end{array}$ & & $\begin{array}{l}\text { tetrahydroxychalcone, } \\
\text { aromatic ketone) }\end{array}$ & $\begin{array}{l}\text { butein-induced apoptosis and tumor inhibition in human } \\
\text { CRC. [471-473]. Synergistic effects of butein and } \\
\text { cisplatin, induce combined inhibition of p38 and MEK } \\
\text { specifically induced apoptosis through caspase-3 in CRC } \\
\text { cells [474]. Butein ameliorated colitis (most important } \\
\text { risk factor of CRC) in IL-10(-/-) mice by regulating IL- } \\
\text { 6/STAT3 and MMP-9 activation [454]. }\end{array}$ \\
\hline $\begin{array}{l}\text { Capsicum annuum } \\
\text { (Chili pepper) }\end{array}$ & Fruit & $\begin{array}{l}\text { E-capsaicin (8-methyl- } \\
\text { N-vanillyl-trans-6- } \\
\text { nonenamide) }\end{array}$ & $\begin{array}{l}\text { Chili peppers can promote digestive juice to secrete and } \\
\text { accelerate bowel movements, which may reduce the risk } \\
\text { of CRC. Capsaicins can downregulate the expression of } \\
\text { COX-2 and B-catenin mRNA, promoting apoptosis } \\
\text { through caspase } 3 \text { activation and inhibiting the } \\
\text { proliferation of cells [455]. Capsaicin Mediates Cell Cycle } \\
\text { Arrest and Apoptosis in Human Colon Cancer Cells via } \\
\text { Stabilizing and Activating p53 [475,476]. Low } \\
\text { concentration capsaicin promotes CRC cell migration } \\
\text { and invasion by triggering production of ROS [477]. }\end{array}$ \\
\hline \begin{tabular}{|} 
Colchicum \\
autumnale (meadow \\
saffron) or Gloriosa \\
superba (glory lily)
\end{tabular} & $\begin{array}{l}\text { Seeds and } \\
\text { bulbs }\end{array}$ & Colchicine & $\begin{array}{l}\text { The cellular uptake and apoptotic efficiency of colchicine } \\
\text { is correlated with downregulation of MMP-9 mRNA } \\
\text { Expression in SW480 CRC cells [478]. Colchicine induces } \\
\text { apoptosis via MMP loss in HT-29 cells, ROS production, } \\
\text { caspase-3 activation, upregulation of pro-apoptotic Bax, } \\
\text { downregulation of anti-apoptotic Bcl-2 and } \\
\text { phosphorylation of p38, which indicates an involvement } \\
\text { of p38-regulated intrinsic apoptosis pathway }[479,480] \text {. }\end{array}$ \\
\hline $\begin{array}{l}\text { Vitis vinifera } \\
\text { (Grape) }\end{array}$ & Seed & Resveratrol & $\begin{array}{l}\text { Resveratrol was found to upregulate miR-96 in a } \\
\text { genetically engineered mouse model for sporadic CRC, } \\
\text { which caused the downregulation of KRAS, an oncogene } \\
\text { associated with tumor aggressiveness and } \\
\text { chemoresistance [481]. Upregulation of miR-101b and } \\
\text { miR-455, which in turn led to decreased levels of IL-6 } \\
\text { and TNF- } \alpha \text {; these are pro-inflammatory proteins known } \\
\text { to be promoters of colon cancer [482,483]. Additionally, } \\
\text { a combination of resveratrol and grape seed extract has } \\
\text { been reported to suppress Wnt/ } \beta \text {-catenin signaling and } \\
\text { increase mitochondria-dependent apoptosis in in vitro } \\
\text { and in vivo models [484]. Finally, resveratrol has been } \\
\text { shown to increase miR-34a levels in DLD-1 and SW480 } \\
\text { cells [485]. }\end{array}$ \\
\hline $\begin{array}{l}\text { Allium cepa } \\
\text { (Red onion) }\end{array}$ & Bulb & Quercetin** & $\begin{array}{l}\text { Cytotoxic activity of Quercetin on two human colonic } \\
\text { cancer cell lines, HT29 and HCT15, depends on COX-2 } \\
\text { dependent ROS generation that induces apoptosis and } \\
\text { inhibits cell survival [486]. In HT-29 colon cancer cells } \\
\text { quercetin treatment decreases cell viability, arrests the } \\
\text { cell cycle at the G1 phase and induces apoptosis, also } \\
\text { Decreases the expression of CSN6, a subunit of the } \\
\text { constitutive photomorphogenesis 9 multiprotein } \\
\text { complex [487]. Additionally, treatment of HT-29 cells } \\
\text { with quercetin upregulates AMP-activated protein } \\
\text { kinase, a physiological cellular energy sensor, which } \\
\text { markedly suppresses cell proliferation [488]. Quercetin } \\
\text { has also been demonstrated to suppress the Wnt/ } \beta-\end{array}$ \\
\hline
\end{tabular}




\section{Advances in Pharmacology and Clinical Trials}

\begin{tabular}{|c|c|c|c|}
\hline & & & catenin and NF-кB pathways in CRC cells $[489,490]$. \\
\hline $\begin{array}{c}\text { Elettaria } \\
\text { cardamomum }\end{array}$ & Bark & Cardamonin (Figure 8g) & $\begin{array}{l}\text { Induction of apoptosis, cell cycle arrest, ROS generation, } \\
\text { downregulation of MAPK signaling, induction of Bax } \\
\text { translocation and loss of mitochondrial integrity were } \\
\text { the mechanisms behind the anti-proliferative effect of } \\
\text { cardamonin in human CRC cell lines. Also, activation of } \\
\text { both p38 and JNK and in presence of ROS scavenger the } \\
\text { activation was attenuated [491]. Suppression of } \beta \text { - } \\
\text { catenin dependent gene expression in human CRC cell } \\
\text { lines [492]. Cardamonin reduces chemotherapy } \\
\text { resistance of colon cancer cells via the TSP50/NF- KB } \\
\text { pathway in vitro [493]. }\end{array}$ \\
\hline $\begin{array}{l}\text { Tripterygium } \\
\text { wilfordii Hook F } \\
\text { (Mandarin) }\end{array}$ & Root & Celastrol (Figure 8h) & $\begin{array}{l}\text { Inhibit the growth, adhesion, and metastasis of human } \\
\text { CRC cells through the inhibition of TGF- } \beta 1 / \text { Smad } \\
\text { signaling [493]. Suppression of the expression of key } \\
\text { genes (TYMP, CDH5, THBS2, LEP, MMP9, and TNF) and } \\
\text { proteins (IL-1b, MMP-9, PDGF, Serpin E1, and TIMP-4) } \\
\text { involved in the angiogenesis pathway [495]. Reduces the } \\
\text { cell size of the SP (side population) increases frequency } \\
\text { of apoptosis and binds to Pgp protein in cell membranes } \\
\text { inhibiting its transport function [496]. Inhibits CRC cell } \\
\text { proliferation and migration through suppression of } \\
\text { MMP3 and MMP7 by the PI3K/AKT signaling pathway } \\
\text { [497]. Effectively inhibited SW480 CRC cell proliferation, } \\
\text { down-regulation of Shoc2 expression also significantly } \\
\text { inhibited proliferation, colony formation, and migration } \\
\text { functions of tumor cells [498]. }\end{array}$ \\
\hline Mundulea sericea & $\begin{array}{l}\text { Bark, roots, } \\
\text { and leaves }\end{array}$ & $\begin{array}{l}\text { Deguelin (Figure 8i) } \\
\text { (Rotenoid, flavonoid) }\end{array}$ & $\begin{array}{l}\text { Deguelin inhibited CRC cell growth by inducing } \\
\text { apoptosis via activation of p38 MAPK pathway [499]. } \\
\text { Promoted cell cycle arrest at G0/G1 phase in colon } \\
\text { cancer cells [500]. Deguelin has been found to regulate } \\
\text { cell cycle in colon cancer cells by stimulating p27 } \\
\text { expression. Cyclin D1 and cyclin E is dramatically } \\
\text { downregulated with treatment of deguelin [501]. } \\
\text { Deguelin exerted anticancer activity of human gastric } \\
\text { cancer MGC-803 and MKN-45 cells in vitro [502]. }\end{array}$ \\
\hline $\begin{array}{l}\text { Trigonella foenum } \\
\text { graecum } \\
\text { (Fenugreek) }\end{array}$ & Seed & $\begin{array}{l}\text { Diosgenin (Figure 8j) } \\
\text { (phytosteroid } \\
\text { sapogenin) }\end{array}$ & $\begin{array}{l}\text { Diosgenin induces apoptosis due to HMG (3-hydroxy-3- } \\
\text { methylglutaryl) CoA suppression in human colon } \\
\text { carcinoma cells [503]. Diosgenin induced apoptosis in } \\
\text { colorectal cancer cell lines HCT-116 and HT-29 [504]. } \\
\text { HT-29 is sensitized by diosgenin to TRAIL induced } \\
\text { apoptosis [505]. Acts on colon carcinoma (HCT-15) cells, } \\
\text { induces apoptosis via mitochondrial dependent pathway } \\
\text { [506]. }\end{array}$ \\
\hline $\begin{array}{c}\text { Darmera peltate } \\
\text { (Indian Rhubarb) } \\
\text { and } \\
\text { Rheum palmatum } \\
\text { (Chinese Rhubarb) }\end{array}$ & $\begin{array}{l}\text { Bark and } \\
\text { roots }\end{array}$ & $\begin{array}{l}\text { Emodin (Figure } \\
\text { (Trihydroxy- } \\
\text { anthraquinone) }\end{array}$ & $\begin{array}{l}\text { Inhibited the invasion and migration abilities of RKO } \\
\text { cells and decreased the expression of MMP-7, MMP-9, } \\
\text { and suppressed the growth of colorectal cancer cells by } \\
\text { inhibiting VEGFR2 [507,508], decreased viability of CoCa } \\
\text { cells and induced apoptosis in a time and dose- } \\
\text { dependent manner, down regulated Bcl-2 family } \\
\text { expression [509]. Mitochondrial dysfunction and ROS } \\
\text { accumulation in colon cancer cells also reported [510]. }\end{array}$ \\
\hline
\end{tabular}




\section{Advances in Pharmacology and Clinical Trials}

\begin{tabular}{|c|c|c|c|}
\hline $\begin{array}{c}\text { Embelia ribes } \\
\text { (White-flowered } \\
\text { Embelia) }\end{array}$ & Fruit & Embelin (Figure 8l) & $\begin{array}{l}\text { In tumor milieu, embelin increased the infiltration of } \\
\text { CD8+ T cells, NK cells and mature dendritic cells whilst } \\
\text { depleted the regulatory T cells. Moreover, embelin could } \\
\text { directly interfere with the generation and function of } \\
\text { MDSCs in vitro [511]. In colon cancer cells, embelin } \\
\text { diminished both the constitutive and IL-6-induced } \\
\text { STAT3 activation by stimulating Src homology domain 2- } \\
\text { containing protein tyrosine phosphatase (SHP2) activity } \\
\text { [512]. Embelin potently inhibited NF-kB signaling in } \\
\text { macrophages and decreased the production of key pro- } \\
\text { inflammatory cytokines and tumorigenic factors } \\
\text { involved in CAC, such as TNF } \alpha \text {, IL- } 6 \text { and COX-2 [513]. }\end{array}$ \\
\hline
\end{tabular}

*Also obtained from stokes of Caragana jubata

** Black currants, apples and cherries are also good sources of quercetin

Table 4: Traditional Plants Used in Colorectal Cancer.<smiles>O=C(/C=C/c1ccc(O)c(O)c1)O[C@H]1[C@@H](O)C[C@@](O)(C(=O)O)C[C@H]1OC(=O)/C=C/c1ccc(O)c(O)c1</smiles>

8(a) 3,4-Di-O-caffeoylquinic acid<smiles>C=CC(C=C)c1ccc(OC(C)=O)cc1</smiles>

8(b) 1'-Acetoxychavicol acetate (ACA)<smiles>COc1cc(/C=C/C(=O)N2CCC=CC2=O)cc(OC)c1OC</smiles>

8(c) Piperlongumine

8(d) Berberine<smiles>[R]c1cccc(O)c1C(=O)O</smiles>

8 (e) Anacardic Acid<smiles>C[n+]1cc2c3c(ccc2c2ccc4cc5c(cc4c21)OCO5)OCO3</smiles>

8(f) Sanguinarine 


\section{Advances in Pharmacology and Clinical Trials}<smiles>COc1cc(O)cc(O)c1C(=O)/C=C/c1ccccc1</smiles>

8(g) Cardamonin

8(h) Celastrol<smiles>COc1cc2c(cc1OC)[C@@H]1C(=O)c3ccc4c(c3O[C@H]1CO2)C=CC(C)(C)O4</smiles><smiles>Cc1cc(O)c2c(c1)C(=O)c1cc(O)cc(O)c1C2=O</smiles>

8(k) Emodin

8(j) Diosgenin<smiles>COCCC1=C(O)C(=O)C=C(O)C1=O</smiles>

8(1) Embelin<smiles>O=C(O)C1O[C@H](Oc2cc3oc(-c4ccc(O)cc4)cc(=O)c3c(O)c2O)[C@H](O)[C@H](O)[C@H]1Br</smiles>

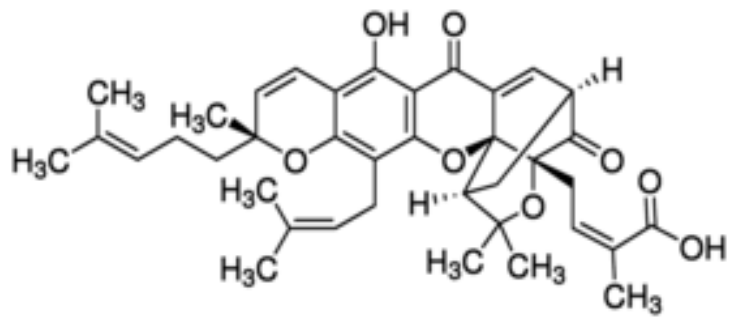

8(n) Gambogic acid

Figure 8: Plant derived biomolecules studied in colorectal cancer.

Aloe-emodin, a natural compound extract from Aloe Vera, has been discovered to suppress cell proliferation and accelerate apoptosis in a variety of tumor cells [514].
Camptothecin induces the upregulation of Programmed Death-Ligand 1(PD-L1) and other cytokines that modulate the attraction, migration, and functions of 


\section{Advances in Pharmacology and Clinical Trials}

immune cells, primarily T-cells [515]. Scutellarin (Figure $8 \mathrm{~m}$ ) is a flavonoid isolated from a medicinal herb Scutellaria barbata (Figure 9a), downregulates the antiapoptotic protein Bcl-2 and induces apoptosis by activating p53, which upregulates Bax to activate caspase 3 via the mitochondrial pathway [516]. Treatment of HT29 cells with luteolin (flavonoid, exist in fruits, vegetables and medicinal herbs) results in a loss of the mitochondrial membrane potential, an increase in mitochondrial $\mathrm{Ca} 2+$ level, upregulation of Bax, downregulation of $\mathrm{Bcl}-2$, release of cytochrome $c$ from the mitochondria to the cytosol and an increase in the levels of the active forms of caspase- 9 and caspase-3 [517]. Treatment of Caco-2 CRC cells with extra virgin olive oil (rich in hydroxytyrosol and oleuropein) miR-23a and miR-301a, which were predicted to target type 1 cannabinoid receptor (CB1) in colon cancer [518], important implications in chemoprevention. Gambogic acid (Figure 8n), a xanthonoid extracted from the resin of Garcinia hanburyi (Figure 9b) inhibits HT-29 proliferation via induction of apoptosis [519]. Walnuts (genus Juglans) have been shown to suppress colon cancer in mice models through the decreased expression of miR-1903, miR-467c, and miR-3068, as well as the increased expression of miR297a in athymic nude mice injected subcutaneously with HT-29 CRC cells [520]. Also, Aggarwal et.al, 2013 listed phytochemicals like garcinol, gossypol, gossypin, guggulsterone, indole-3-carbinol, morin, naphthoquinone, nimbolide, noscapine, oleandrin, piperine, piceatannol, pinitol, plumbagin, pomegranate, retnoids, honokiol, sesamin, silymarin, simvastatin, terpenoid, thymoquinone, tocotrienol, triptolide, ursolic acid, withanolides, xanthohumol, and zerumbone [458] having potentials in CRC. Seaweeds like U. pinnatifida [175], [401], [521-527], Saccharina latissimi (9c) [528], Fucus vesiculosus [176], [295], [529,530], Sargassum hemiphyllum (Figure 9d) [531-533] have proven efficacy in this situation. Also, Algae derived astaxanthin [534540], fucoxanthin [541-545], lutein and zeaxanthin [546549], polyphenols [550-554] shown individual excellence (Figure 9).

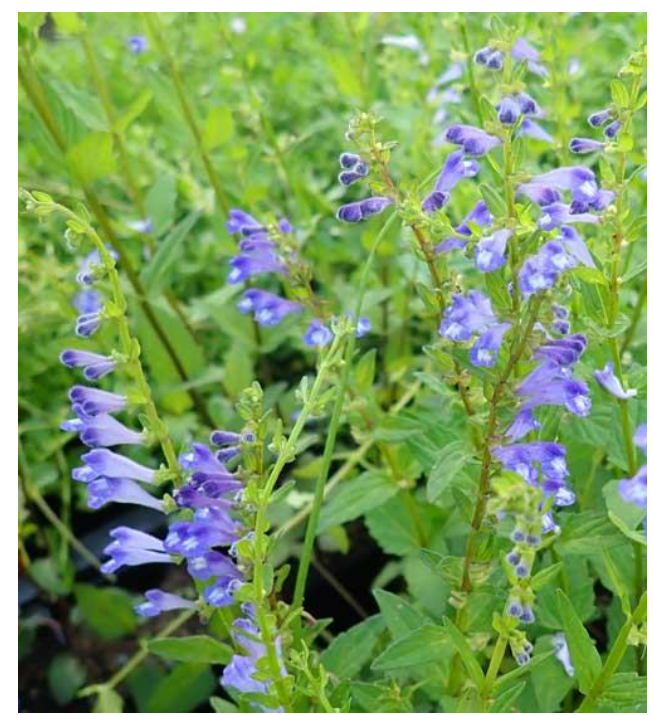

9 (a) Scutellaria barbata (Source: Strictly Medicinal Seeds)

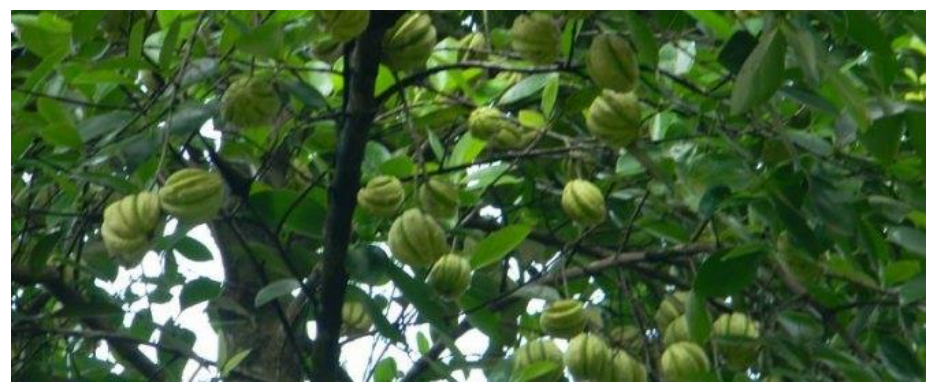

9 (b) Garcinia hanburyi (Source: Vitamin Supplement Ingredients Information) 


\section{Advances in Pharmacology and Clinical Trials}

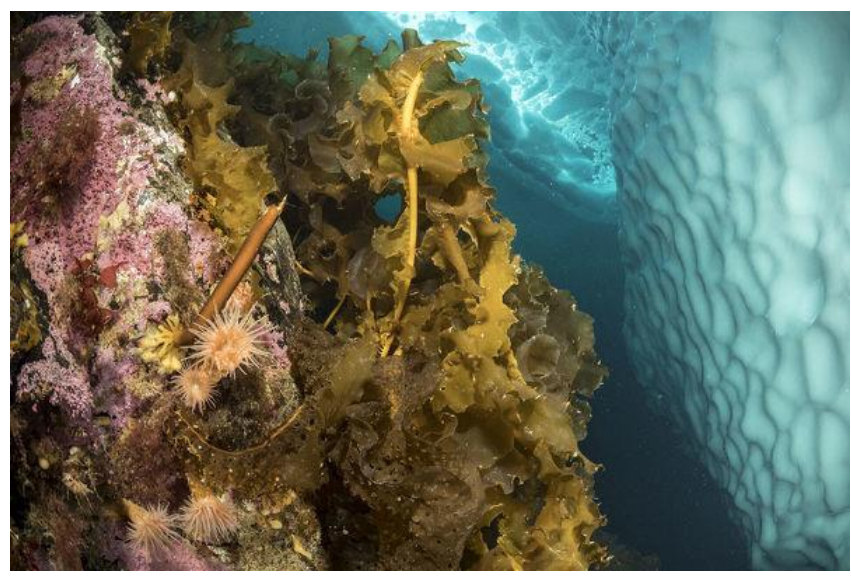

9 (c) Saccharina latissimi (Source: Nature Picture Library Print Store)

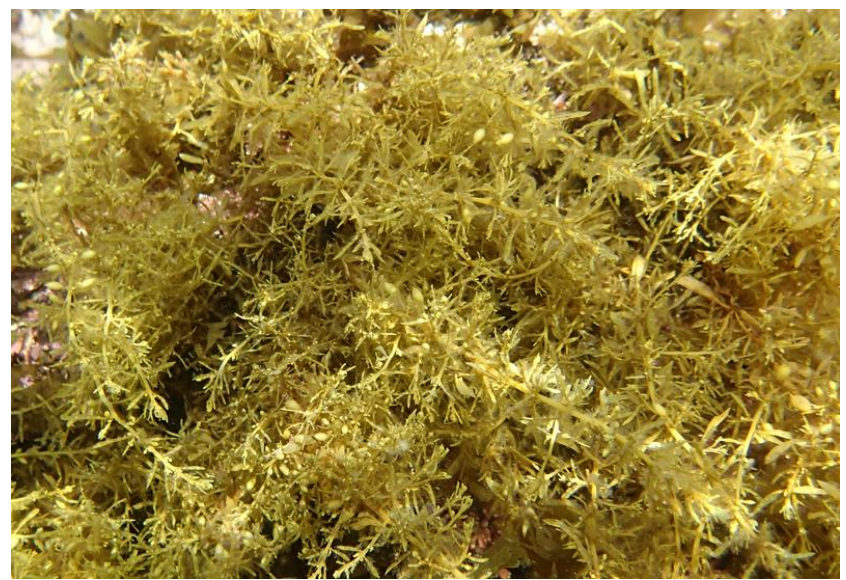

9(d) Sargassum hemiphyllum (Source: natural-history.main.jp)

Figure 9: Plants studied in colorectal cancer

\section{Other Bioactive Non-Plant Compounds}

Caffeic acid phenethyl ester (Figure 10a) is a central active component of propolis from honeybee hives. Propolis is a well-known health supplement that is extremely popular in Australia and New Zealand. It is constantly marketed in Japan with sales exceeding US\$300 million/year [555]. It can impart strong antimitogenic activity in lung cancer, breast cancer [556] and apoptosis in colon cancer [557]. Peripheral neuropathy is a common side effect of many chemotherapeutic agents including paclitaxel. Poor nutritional status and obesity increase the risk of paclitaxel induced neuropathy [558]. PEGylated liposomes of paclitaxel were successfully developed and demonstrated reduced neurotoxicity in-vitro in neuronal cells and prevented development of peripheral neuropathy in-vivo [559]. Glutathione [560] and gallic acid [561] may ameliorate paclitaxel-induced neuropathic pain. Di(2-ethylhexyl) phthalate (DEHP) (Figure 10b), estrogen receptor alpha $(E R \alpha)$ agonist due to its ability to interact with ER $\alpha$ and promote the cell proliferation of $E R \alpha$-positive breast cancer cells, significantly protected MCF-7 cells against the genotoxicity of camptothecin [562]. Actinomycin D obtained from various Streptomyces strains decreases Mcl-1 expression in lung cancer cells [563], induces p53-independent cell death in leukemia [564], synergistically suppressed multiple metastasis of TRAIL-resistant colon cancer in the liver with soluble TRAIL gene [565]. Hyperthermic intraperitoneal chemotherapy (HIPEC) with cisplatin and mitomycin C (Figure 10c) (obtained from Streptomyces caespitosus) is the only protocol to demonstrate an adjuvant HIPEC benefit in colorectal cancer patients at high risk for peritoneal failure and an alternative to highdose and short-term oxaliplatin [566]. 5-FU plus mitomycin remains the preferred chemotherapy in most patients with anal cancer [567]. Bleomycin (Figure 10e) is an antibiotic complex of several glycopeptides derived from Streptomyces verticillus, gained FDA approval in July 1973. The extract from Streptomyces sp. MUM265represents a valuable bioresource of bioactive compounds for the future development of chemopreventive agents, with particular promise suggested for treatment of colon cancer [568]. Bleomycin is an indispensable antineoplastic agent for the treatment of germ cell tumors and lymphomas. Pirfenidone (Figure 10d) (novel orally available antifibrotic drug approved by the FDA in 2014) is currently the only approved therapy for idiopathic pulmonary fibrosis (IPF), considered as a salvage drug for refractory cases of bleomycin-induced lung injury [569]. In a similar study, Yu, et al. [570] reported EZY-1 (16-amino-acid peptide was isolated from Eucheuma) can inhibit the IPF induced by bleomycin (Figure 10). 


\section{Advances in Pharmacology and Clinical Trials}<smiles>O=C(/C=C/c1ccc(O)c(O)c1)OCCc1ccccc1</smiles><smiles>CCCCC(CC)COC(=O)c1ccccc1C(=O)OCC(CC)CCCC</smiles>

10(a) Caffeic acid phenethyl ester

10 (b) Di(2-ethylhexyl) phthalate (DEHP)<smiles>CO[C@]12[C@H](COC(N)=O)C3=C(C(=O)C(C)=C(N)C3=O)N1C[C@H]1N[C@H]12</smiles>

10(c) Mitomycin C<smiles>Cc1ccc(=O)n(-c2ccccc2)c1</smiles>

10 (d) Pirfenidone

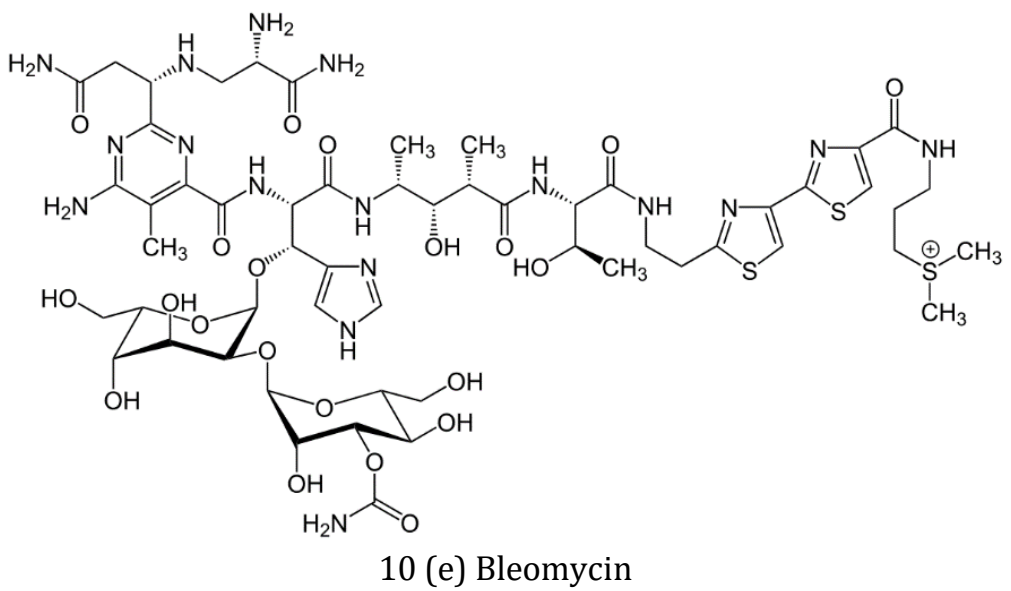

Figure 10: Biomolecules from non-plant origin studied or used in different types cancers.

\section{Alternative therapies and Mind-Body Interventions}

According to the Global Health Observatory Report from the WHO, insufficient physical activity is the 4th leading risk factor for mortality. Participation in 150 minutes of moderate physical activity a week or its equivalent is estimated to reduce risk of breast and colon cancer by $21 \%-25 \%$ [571]. Approximately $50 \%$ of all leukemia, lymphoma, colorectal- and breast cancer patients are affected by CIPN. Sensorimotor training 


\section{Advances in Pharmacology and Clinical Trials}

(SMT) or whole-body vibration (WBV) can reduce the symptoms of CIPN and attenuate motor and sensory deficits [572]. Hypnosis, music (Figure 11) and relaxing video reduced anxiety and pain associated with colonoscopy and need for sedation during colon cancer screening [573-581]. Impaired cognitive function, change in brain metabolism and change in brain structure are associated with cancer treatment. CBT moderately improved anxiety and depression in patients with earlystage breast cancer [582], significantly improved tumor associated fatigue levels after 8 weeks [583], improved QoL [584], improved cognitive function [585], improved insomnia [586,587], reduced fear of cancer recurrence [588] and most importantly, reduced pain and distress [589]. Mindfulness-based approaches and hypnosis reduced demonstrated efficacy in reducing anxiety and depressive symptoms. $40 \%$ to $50 \%$ CRC patients reported fear of cancer recurrence, tends to increase around the time of scans or other testing for recurrence [590]. Also, CRC patients have unique psychosocial needs (e.g., isolation, embarrassment) related to altered eating and bowel habits and sexual dysfunction that warrant clinical attention [591]. Acceptance and commitment therapy, meta-cognitive therapy, and mindfulness-based therapies emphasize mindfulness, acceptance, cognitive flexibility, and patient values changes in self-efficacy or confidence in using coping skills targeted by the intervention, acceptance of unwanted thoughts and feelings, or enhanced social support as well as physiological mechanisms (e.g., decreased arousal to negative thoughts and feelings about cancer) [592]. Combined CBT/GET improves fatigue and functional outcomes for a subset of patients with post-cancer fatigue in breast or colon cancer [593]. CBT intervention has the potential to ease acute anxiety during the often-challenging re-entry phase and to prevent the development of chronic, debilitating, and costly anxiety [594]. Physical activity interventions also reduce depressive and anxiety symptoms in breast cancer survivors [595]. Telehealth approaches may improve access to mental health resources especially for those with limited online access or lack of online skill [596]. Yoga has a solid effect on cancer-related fatigue in patients with breast cancer [597]. It is one of the most prevalent complementary therapies used in breast cancer care, seems to be as effective as other exercise modalities for improving the QoL of women with breast cancer [598]. Wei, et al. [599] reported significant improvement in lymphedema status, range of shoulder motion and spinal mobility after an 8-week yoga intervention [599]. Although, yoga could not improve HRQoL in patients with colorectal cancer [600] but research supports that yoga is a promising intervention for reducing fatigue and sleep disturbances in this patient group [601]. dyadic yoga may offer effective relaxation techniques for lung cancer patients and their caregivers who were undergoing an extreme stressor in addition to the cancer experience [602], feasible and beneficial for patients having toxic thoracic radiography [603]. Approximately $20 \%$ of breast cancer survivors develop breast cancer-related lymphedema (BCRL) [604]. Acupuncture is safe and effective at reducing breast cancer-related lymphoedema in patients after breast cancer treatment [605] and managing joint stiffness. Acupuncture use among breast cancer patients in the US is currently as high as $16 \%$ to $63 \%$ [606]. At the current time breast cancer related lymphedema is incurable but well manageable by a number of physical therapy modalities, especially complete decongestive therapy (CDT) [607]. Obesity is a factor that deteriorates the CDT efficacy. Early treatment, before developing fat accumulation and fibrosis, must be primary goal in the treatment of BCRL [608]. The first "intensive treatment" phase aims to decongest the swollen arm through two or more weeks of daily therapist-delivered treatment including multi-layer compression bandaging and manual lymph drainage (MLD). This is followed by a "maintenance" phase of patient self-treatment, with compression usually in the form of hosiery [609]. The mindfulness component may enhance the positive impact of exercise on cognitive function in breast cancer $[610,611]$. Tai Chi is accessible to most people and does not require special facilities or expensive equipment [612]. Healthier dietary choices were the most frequently reported change already made by people affected by CRC, followed by increased physical activity, stress management, quitting smoking and alcohol and therapies including meditation, tai chi, and naturopathy [613]. Greater shoulder muscular strength was significantly associated with better functional wellbeing in breast cancer survivors with TC Qigong training [614]. Massage with or without aromatherapy have been suggested by a few studies in breast cancer to ameliorate anxiety and other symptom relief [615] and immunologic state [616] that needs further investigation. TENS was found valuable in lung cancer patient underwent standard posterolateral thoracotomy [617]. Animal-assisted activities (Figure 12) has potential benefit children with cancer because pediatric oncology patients often suffer from distress due to physical examinations, venipuncture, chemotherapy infusions, spinal taps, surgery, hospitalization, pain, fear of medical procedures, unpleasant physical symptoms, uncertainty, and worry about death [618]. 


\section{Advances in Pharmacology and Clinical Trials}

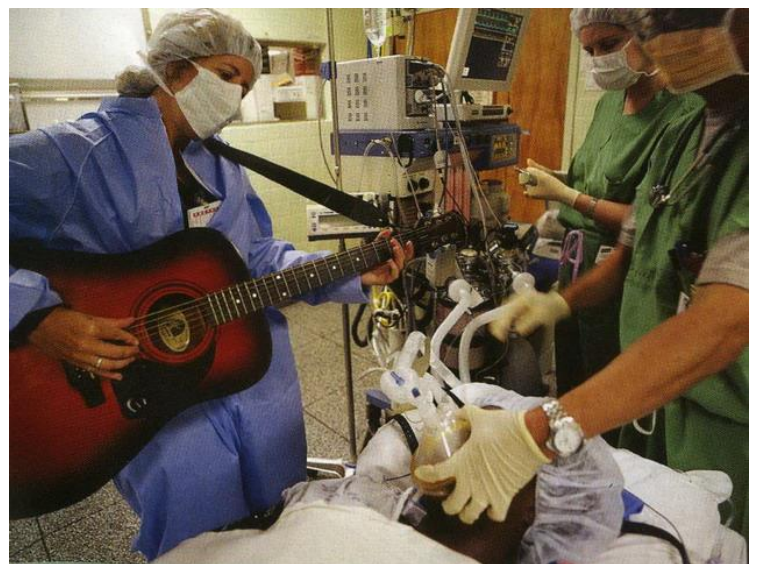

Figure 11: Music Therapy: Pain or Distress Management [619].

In the UK, music therapists are trained to master's level and are registered with Health and Care Professions Council as allied health professionals. Aristotle recognized the innate ability of melodies to surpass "feelings such as pity and fear, or enthusiasm," and thus "heal and purify the soul." The Greeks identified Apollo as the father of both healing and music, alongside his many other accolades (as God of light, sun, truth, prophecy, plague and poetry).

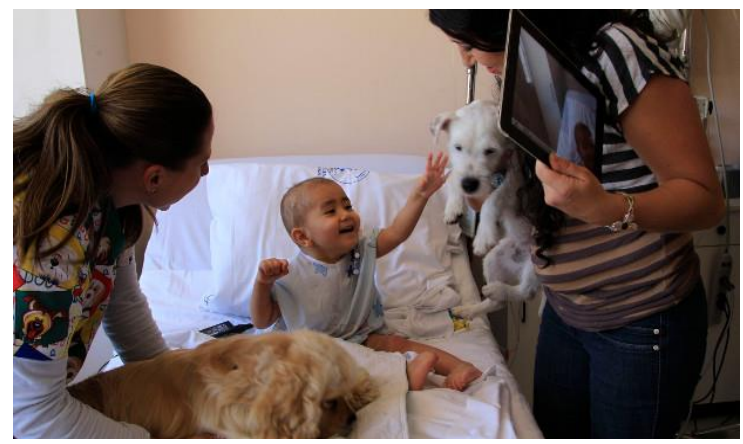

Figure 12: Hospitalized kid on animal visit [620].

Understanding whether AAA is safe and effective for pediatric cancer patients is critical, especially because of concern about infection in immunosuppressed persons. Conducting AAA research in pediatric oncology requires understanding current regulations and variations in practice. Knowledge of regulations helps us understand elements required for intervention protocols (e.g., handcleaning), whereas knowledge of practice variation can help us identify research opportunities.

\section{Conclusion}

The journey from diagnosis to treatment of cancer affects the patients' lives in a variety of ways. Debilitating symptoms arising both due to disease and its treatments consistently hamper their QoLs. CAM treatment aims to restore body's ability to protect, regulate and heal itself. Since almost $50 \%$ of existing medicine is derived from plants, it is clear that natural sources, especially plants can be investigated for effective medicines in cancer treatment. These data can equip providers and patients with the information they need to have informed conversations regarding non-drug approaches for treatment of specific cancer conditions. The use of CAM by cancer patients is becoming widespread. This is a reflection of the many needs and concerns that are currently not being met by conventional medical practice. Significant proportions of cancer patients in developed countries use complementary therapies as adjuncts to conventional symptom management to improve their QoL. India's indigenous systems of medicine, such as Ayurveda, Siddha, and Unani, are more than 5,000 years old, and in rural areas, the Indian population has relied heavily on these practices, particularly Ayurveda. In addition, CAM has the potential for the primary and secondary prevention of cancer through counselling on healthy lifestyle, nutrition and supporting the human power of 'salutogenesis' throughout life. The lack of communication about CAM use may be due to fear of a negative response, physicians being perceived as not supportive nor helpful, or physicians and patients having differing views about CAM. Discussions of CAM therapies may have additional benefits for the patient-provider relationship, as studies have shown it indicates use of participatory decision-making, patient-centered communication, and thus greater patient satisfaction, not only in cancer care but also in other arenas of healthcare.

\section{Acknowledgement}

I'm thankful to Dr. Alexandra McCarthy, The University of Auckland, New Zealand for her valuable time to audit my paper and for her thoughtful suggestions. I'm also grateful to seminar library of Faculty of Pharmacy, University of Dhaka and BANSDOC Library, Bangladesh for providing me books, journal and newsletters.

\section{References}

1. Ducharme JA (2019) Third of People with Cancer Use Alternative Medicine. Here's Why That Could Be Dangerous. Time Magazine. 


\section{Advances in Pharmacology and Clinical Trials}

2. PDQ Integrative (2018) Topics in Integrative, Alternative, and Complementary Therapies (PDQ®). PDQ Cancer Information Summaries.

3. Siegel RL, Miller KD, Jemal A (2019) Cancer statistics, 2019. CA Cancer J Clin 69(1): 7-34.

4. Shah SC, Kayamba V, Peek RM, Heimburger D (2019) Cancer Control in Low- and Middle-Income Countries: Is It Time to Consider Screening? J Glob Oncol 5: 1-8.

5. Ferlay J, Colombet M, Soerjomataram I, Mathers C, Parkin DM, et al. (2019) Estimating the global cancer incidence and mortality in 2018: GLOBOCAN sources and methods. Int J Cancer 144(8): 1941-1953.

6. Feng RM, Zong YN, Cao SM, Xu RH (2019) Current cancer situation in China: good or bad news from the 2018 Global Cancer Statistics? Cancer Commun (Lond) 39(1): 22.

7. WHO (2018) latest global cancer data: Cancer burden rises to 18.1 million new cases and 9.6 million cancer deaths in 2018. International Agency for Research on Cancer.

8. Li M, Chen Z, Liu Z, Zhang N, Liu J, et al. (2019) Twelve Chinese herbal preparations for the treatment of depression or depressive symptoms in cancer patients: a systematic review and meta-analysis of randomized controlled trials. BMC Complement Altern Med 19(1): 28.

9. Schüz J, Espina C, Wild CP (2019) Primary prevention: a need for concerted action. Mol Oncol 13(3): 567578.

10. American Cancer Society (2018) Cancer Facts \& Figures 2018.

11. Global Burden of Disease Cancer Collaboration, Fitzmaurice C, Allen C, Barber RM, Barregard L, et al. (2017) Global, Regional, and National Cancer Incidence, Mortality, Years of Life Lost, Years Lived With Disability, and Disability-Adjusted Life-years for 32 Cancer Groups, 1990 to 2015: A Systematic Analysis for the Global Burden of Disease Study. JAMA Oncol 3(4): 524-548.

12. WHO (2018) Cancer. Health Topics.

13. Mohiuddin AK (2019) Non-drug pain management: opportunities to explore. BiomedGrid LLC, USA.
14. Bray F, Ferlay J, Soerjomataram I, Siegel RL, Torre LA, et al. (2018) Global cancer statistics 2018: GLOBOCAN estimates of incidence and mortality worldwide for 36 cancers in 185 countries. CA Cancer J Clin 68(6): 394-424.

15. Rawla P, Barsouk A (2019) Epidemiology of gastric cancer: global trends, risk factors and prevention. Prz Gastroenterol 14(1): 26-38.

16. Rawla P, Sunkara T, Gaduputi V (2019) Epidemiology of Pancreatic Cancer: Global Trends, Etiology and Risk Factors. World J Oncol 10(1): 10-27.

17. Moradi A, Zamani M, Moudi EA (2019) systematic review and meta-analysis on incidence of prostate cancer in Iran. Health Promot Perspect 9(2): 92-98.

18. Rawla P (2019) Epidemiology of Prostate Cancer. World J Oncol 10(2): 63-89.

19. Waks AG, Winer EP (2019) Breast Cancer Treatment: A Review. JAMA 321(3): 288-300.

20. Malvezzi M, Carioli G, Bertuccio P, Boffetta P, Levi F, et al. (2019) European cancer mortality predictions for the year 2019 with focus on breast cancer. Ann Oncol 30(5): 781-787.

21. Miller KD, Nogueira L, Mariotto AB, Rowland JH, Yabroff KR, et al. (2019) Cancer treatment and survivorship statistics, 2019. CA Cancer J Clin 69(5): 363-385.

22. De Santis CE, Miller KD, Goding Sauer A, Jemal A, Siegel RL (2019) Cancer statistics for African Americans, 2019. CA Cancer J Clin 69(3): 211-233.

23. Layne TM, Graubard BI, Ma X, Mayne ST, Albanes D (2019) Prostate cancer risk factors in black and white men in the NIH-AARP Diet and Health Study. Prostate Cancer Prostatic Dis 22(1): 91-100.

24. Ghose S, Radhakrishnan V, Bhattacharya S (2019) Ethics of cancer care: beyond biology and medicine. E cancer medical science 13: 911.

25. Allcott N, Dunham L, Levy D, Carr J, Stitzenberg K (2019) Financial burden amongst cancer patients treated with curative intent surgery alone. Am J Surg 218(3): 452-456.

26. Coumoundouros C, Ould Brahim L, Lambert SD, McCusker J (2019) The direct and indirect financial 


\section{Advances in Pharmacology and Clinical Trials}

costs of informal cancer care: A scoping review 27(5): e622-e636.

27. WHO (2018) $\$ 46$ billion in productivity lost to cancer in major emerging economies. Presse Release.

28. World Cancer Day.

29. PDQ (2019) Cancer Prevention Overview (PDQ®), Health Professional Version. PDQ Cancer Information Summaries.

30. Sung H, Siegel RL, Rosenberg PS, Jemal A (2019) Emerging cancer trends among young adults in the USA: analysis of a population-based cancer registry. Lancet Public Health 4(3): e137-e147.

31. Park B, You S, Cho WCS, Choi JY, Lee MS (2019) A systematic review of herbal medicines for the treatment of cancer cachexia in animal models. J Zhejiang Univ Sci B 20(1): 9-22.

32. Zhang Q (2015) Traditional and Complementary Medicine in Primary Health Care. Health for All: The Journey of Universal Health Coverage.

33. Mawoza T, Nhachi C, Magwali T (2019) Prevalence of Traditional Medicine Use during Pregnancy, at Labour and for Postpartum Care in a Rural Area in Zimbabwe. Clinics in mother and child health 16(2): 321.

34. Krupa J, Sureshkumar J, Silambarasan R, Priyadarshini K, Ayyanar M (2019) Integration of traditional herbal medicines among the indigenous communities in Thiruvarur District of Tamil Nadu, India. Journal of Ayurveda and integrative medicine 10(1): 32-37.

35. Wode K, Henriksson R, Sharp L, Stoltenberg A, Hök Nordberg J (2019) Cancer patients' use of complementary and alternative medicine in Sweden: a cross-sectional study. BMC Complement Altern Med 19(1): 62.

36. Jermini M, Dubois J, Rodondi PY, Zaman K, Buclin T, et al. (2019) Complementary medicine use during cancer treatment and potential herb-drug interactions from a cross-sectional study in an academic centrer 9(1): 5078.

37. Kwon JH, Lee SC, Lee MA, Kim YJ, Kang JH, et al. (2019) Behaviors and Attitudes toward the Use of Complementary and Alternative Medicine among
Korean Cancer Patients. Cancer Res Treat 51(3): 851860.

38. Jones E, Nissen L, McCarthy A, Steadman K, Windsor C (2019) Exploring the Use of Complementary and Alternative Medicine in Cancer Patients. Integr Cancer Ther 18: 1534735419854134.

39. Chotipanich A, Sooksrisawat C, Jittiworapan B (2019) Association between complementary and alternative medicine use and prolonged time to conventional treatment among Thai cancer patients in a tertiarycare hospital. Peer J 7: e7159.

40. Ekor M (2014) The growing use of herbal medicines: issues relating to adverse reactions and challenges in monitoring safety. Front Pharmacol 4: 177.

41. Haefeli WE, Carls A (2014) Drug interactions with phytotherapeutics in oncology. Expert Opin Drug Metab Toxicol 10(3): 359-377.

42. Kabat G (2018) Why Resorting to Alternative Medicine to Treat Cancer is a Bad Idea.

43. Caraceni A, Shkodra M (2019) Cancer Pain Assessment and Classification. Cancers (Basel) 11(4).

44. Derry S, Wiffen PJ, Moore RA, McNicol ED, Bell RF, et al. (2017) Oral nonsteroidal anti-inflammatory drugs (NSAIDs) for cancer pain in adults. Cochrane Database Syst Rev 7: CD012638.

45. Bennett MI, Kaasa S, Barke A, Korwisi B, Rief W, et al. (2019) IASP Taskforce for the Classification of Chronic Pain. The IASP classification of chronic pain for ICD-11: chronic cancer-related pain. Pain 160(1): 38-44.

46. Asthana R, Goodall S, Lau J, Zimmermann C, Diaz PL, et al. (2019) Framing of the opioid problem in cancer pain management in Canada. Curr Oncol 26(3): e410e413.

47. Johnson M, Collett B, Castro-Lopes JM (2013) The challenges of pain management in primary care: a pan-European survey. J Pain Res 6: 393-401.

48. Jones MR, Viswanath O, Peck J, Kaye AD, Gill JS, et al. (2018) A Brief History of the Opioid Epidemic and Strategies for Pain Medicine. Pain Ther 7(1): 13-21.

49. Oelhaf RC, Azadfard M, Kum B (2019) Opioid Toxicity. StatPearls. 


\section{Advances in Pharmacology and Clinical Trials}

50. Gallagher R (2018) New category of opioid-related death. Can Fam Physician 64(2): 95-96.

51. Roland CL, Ye X, Stevens V, Oderda GM (2019) The Prevalence and Cost of Medicare Beneficiaries Diagnosed and At Risk for Opioid Abuse, Dependence, and Poisoning. J Manag Care Spec Pharm 25(1): 1827.

52. Shah M, Huecker MR (2019) Opioid Withdrawal. Stat Pearls.

53. Magee DJ, Jhanji S, Poulogiannis G, Farquhar-Smith P, Brown MRD (2019) Nonsteroidal anti-inflammatory drugs and pain in cancer patients: a systematic review and reappraisal of the evidence. Br J Anaesth 123(2): e412-e423.

54. Wong RSY (2019) Role of Nonsteroidal AntiInflammatory Drugs (NSAIDs) in Cancer Prevention and Cancer Promotion. Adv Pharmacol Sci.

55. Cuomo A, Bimonte S, Forte CA, Botti G, Cascella M (2019) Multimodal approaches and tailored therapies for pain management: the trolley analgesic model. J Pain Res 12: 711-714.

56. Nair AS (2019) Cardiovascular Safety of Naproxen for Treating Cancer and Noncancer Chronic Pain. Indian J Palliat Care 25(1): 164-165.

57. Wongrakpanich S, Wongrakpanich A, Melhado K, Rangaswami J (2018) A Comprehensive Review of Non-Steroidal Anti-Inflammatory Drug Use in The Elderly. Aging Dis 9(1): 143-150.

58. Brasky TM, Bonner MR, Moysich KB, Ambrosone CB, Nie J, et al. (2011) Non-steroidal anti-inflammatory drugs (NSAIDs) and breast cancer risk: differences by molecular subtype. Cancer Causes Control 22(7): 965975.

59. Choueiri TK, Je Y, Cho E (2014) Analgesic use and the risk of kidney cancer: a meta-analysis of epidemiologic studies. Int J Cancer 134(2): 384-396.

60. Byars T, Theisen E, Bolton DL (2019) Using Cannabis to Treat Cancer-Related Pain. Semin Oncol Nurs 35(3): 300-309.

61. Dzierżanowski T (2019) Prospects for the Use of Cannabinoids in Oncology and Palliative Care Practice: A Review of the Evidence. Cancers (Basel) 11(2).
62. Carr, Daniel, Michael Schatman (2019) Cannabis for Chronic Pain: Not Ready for Prime Time. American Journal of Public Health 109(1): 50-51.

63. Sharafi G, He H, Nikfarjam M (2019) Potential Use of Cannabinoids for the Treatment of Pancreatic Cancer. J Pancreat Cancer 5(1): 1-7.

64. Campbell G, Stockings E, Nielsen S (2019) Understanding the evidence for medical cannabis and cannabis-based medicines for the treatment of chronic non-cancer pain. Eur Arch Psychiatry Clin Neurosci 269(1): 135-144.

65. Stockings E, Campbell G, Hall WD, Nielsen S, Zagic D, et al. (2018) Cannabis and cannabinoids for the treatment of people with chronic non cancer pain conditions: a systematic review and meta-analysis of controlled and observational studies. Pain 159(10): 1932-1954.

66. Wang J, Wang Y, Tong M, Pan H, Li D (2019) New Prospect for Cancer Cachexia: Medical Cannabinoid. J Cancer 10(3): 716-720.

67. Turgeman I, Bar-Sela G (2019) Cannabis for cancer illusion or the tip of an iceberg: a review of the evidence for the use of Cannabis and synthetic cannabinoids in oncology. Expert Opin Investig Drugs 28(3): 285-296.

68. Urits I, Borchart M, Hasegawa M, Kochanski J, Orhurhu V, et al. (2019) An Update of Current Cannabis-Based Pharmaceuticals in Pain Medicine. Pain Ther 8(1): 41-51.

69. Lossignol D (2019) Cannabinoids: a new approach for pain control? Curr Opin Oncol 31(4): 275-279.

70. Steele G, Arneson T, Zylla D (2019) A Comprehensive Review of Cannabis in Patients with Cancer: Availability in the USA, General Efficacy, and Safety. Curr Oncol Rep 21(1): 10

71. Mead A (2019) Legal and Regulatory Issues Governing Cannabis and Cannabis-Derived Products in the United States. Front Plant Sci 10: 697.

72. Shi S, Brant AR, Sabolch A, Pollom E (2019) False News of a Cannabis Cancer Cure. Cureus 11(1): e3918.

73. Wilkinson ST (2013) Medical and recreational marijuana: commentary and review of the literature. Mo Med 110(6): 524-528. 


\section{Advances in Pharmacology and Clinical Trials}

74. Boehnke KF, Gangopadhyay S, Clauw DJ, Haffajee RL (2019) Qualifying Conditions Of Medical Cannabis License Holders In The United States. Health Aff (Millwood) 38(2): 295-302.

75. Stuyt E (2018) The Problem with the Current High Potency THC Marijuana from the Perspective of an Addiction Psychiatrist. Mo Med 115(6): 482-486.

76. Kansagara D, O'Neil M, Nugent S, Freeman M, Low A, et al. (2017) Benefits and Harms of Cannabis in Chronic Pain or Post-traumatic Stress Disorder: A Systematic Review.

77. Pacula RL, Smart R (2017) Medical Marijuana and Marijuana Legalization. Annu Rev Clin Psychol 13: 397-419.

78. Dariš B, Tancer Verboten M, Knez Ž, Ferk P (2019) Cannabinoids in cancer treatment: Therapeutic potential and legislation. Bosn J Basic Med Sci 19(1): 14-23.

79. Gonçalves J, Rosado T, Soares S, Simão AY, Caramelo $D$, et al. (2019) Cannabis and Its Secondary Metabolites: Their Use as Therapeutic Drugs, Toxicological Aspects, and Analytical Determination. Medicines (Basel) 6(1).

80. Cooke AC, Knight KR, Miaskowski C (2019) Patients' and clinicians' perspectives of co-use of cannabis and opioids for chronic non-cancer pain management in primary care. Int J Drug Policy 63: 23-28.

81. Huang MY, Zhang LL, Ding J, Lu JJ (2018) Anticancer drug discovery from Chinese medicinal herbs. Chin Med 13: 35.

82. Li K, Giustini D, Seely D (2019) A systematic review of acupuncture for chemotherapy-induced peripheral neuropathy. Curr Oncol 26(2): e147-e154.

83. Chou HL, Chao TY, Chen TC, Chu CM, Hsieh CH, et al. (2019) Chemotherapy agents induce tartrateresistant acid phosphatase 5 a contributing to the symptom distress in lung cancer patients. Eur J Pharmacol 846: 38-48.

84. Bonhof CS, van de Poll-Franse LV, Vissers PAJ, Wasowicz DK, Wegdam JA, et al. (2019) Anxiety and depression mediate the association between chemotherapy-induced peripheral neuropathy and fatigue: Results from the population-based PROFILES registry. Psychooncology 28(9): 1926-1933.
85. Chui PL (2019) Cancer- and Chemotherapy-Related Symptoms and the Use of Complementary and Alternative Medicine. Asia Pac J Oncol Nurs 6(1): 4-6.

86. Munzone E, Bagnardi V, Campennì G, Mazzocco K, Pagan E, et al. (2019) Preventing chemotherapyinduced alopecia: a prospective clinical trial on the efficacy and safety of a scalp-cooling system in early breast cancer patients treated with anthracyclines. $\mathrm{Br}$ J Cancer 121(4): 325-331.

87. Hain BA, Xu H, Wilcox JR, Mutua D, Waning DL, et al. (2019) Chemotherapy-induced loss of bone and muscle mass in a mouse model of breast cancer bone metastases and cachexia. JCSM Rapid Commun 2(1): $\mathrm{e} 00075$.

88. Dy SM, Isenberg SR, Al Hamayel NA (2017) Palliative Care for Cancer Survivors. Med Clin North Am 101(6): 1181-1196.

89. Lee YH (2019) Spiritual Care for Cancer Patients. Asia Pac J Oncol Nurs 6(2): 101-103.

90. Karim L (2019) Palliative Care: the new healthcare frontier. The daily Star.

91. AK Mohiuddin (2019) Community and Clinical Pharmacists in Transition Care. Glob J Pharmaceu Sci 7(2): 555706.

92. Khan H, Saeedi M, Nabavi SM, Mubarak MS, Bishayee A (2019) Glycosides from Medicinal Plants as Potential Anticancer Agents: Emerging Trends towards Future Drugs. Curr Med Chem 26(13): 23892406.

93. Kuruppu AI, Paranagama P, Goonasekara CL (2019) Medicinal plants commonly used against cancer in traditional medicine formulae in Sri Lanka. Saudi Pharm J 27(4): 565-573.

94. Tuama AA, Mohammed AA. Phytochemical screening and in vitro antibacterial and anticancer activities of the aqueous extract of Cucumis sativus. Saudi J Biol Sci 26(3):600-604.

95. Seca AML, Pinto DCGA (2018) Plant Secondary Metabolites as Anticancer Agents: Successes in Clinical Trials and Therapeutic Application. Int J Mol Sci 19(1).

96. Alves-Silva JM, Romane A, Efferth T, Salgueiro L (2017) North African Medicinal Plants Traditionally Used in Cancer Therapy. Front Pharmacol 8: 383. 


\section{Advances in Pharmacology and Clinical Trials}

97. Tariq A, Sadia S, Pan K, Ullah I, Mussarat S, et al. (2017) A systematic review on ethnomedicines of anti-cancer plants. Phytother Res 31(2): 202-264.

98. Gezici S, Şekeroğlu N (2019) Current Perspectives in the Application of Medicinal Plants Against Cancer: Novel Therapeutic Agents. Anticancer Agents Med Chem 19(1): 101-111.

99. Lichota A, Gwozdzinski K (2018) Anticancer Activity of Natural Compounds from Plant and Marine Environment. Int J Mol Sci 19(11).

100. Mushtaq S, Abbasi BH, Uzair B, Abbasi R (2018) Natural products as reservoirs of novel therapeutic agents. EXCLI J 17: 420-451.

101. Dutt R, Garg V, Khatri N, Madan AK (2019) Phytochemicals in Anticancer Drug Development. Anticancer Agents Med Chem 19(2): 172-183.

102. Qi F, Zhao L, Zhou A, Zhang B, Li A, et al. (2015) The advantages of using traditional Chinese medicine as an adjunctive therapy in the whole course of cancer treatment instead of only terminal stage of cancer. Biosci Trends 9(1): 16-34.

103. Wong W, Chen BZ, Lee AKY, Chan AHC, Wu JCY, et al. (2019) Chinese Herbal Medicine Effectively Prolongs the Overall Survival of Pancreatic Cancer Patients: A Case Series. Integr Cancer Ther 18:1534735419828836.

104. Jiao L, Xu J, Sun J, Chen Z, Gong Y, et al. (2019) Chinese Herbal Medicine Combined With EGFR-TKI in EGFR Mutation-Positive Advanced Pulmonary Adenocarcinoma (CATLA): A Multicenter, Randomized, Double-Blind, Placebo-Controlled Trial. Front Pharmacol 10: 732.

105. Shen S, Jiang S (2019) Chinese herbal medicines of supplementing Qi and nourishing Yin combined with chemotherapy for non-small cell lung cancer: A metaanalysis and systematic review. J Cell Biochem 120(6): 8841-8848.

106. Wu J, Liu Y, Fang C, Zhao L, Lin L, et al. (2019) Traditional Chinese Medicine Preparation Combined Therapy May Improve Chemotherapy Efficacy: A Systematic Review and Meta-Analysis. Evid Based Complement Alternat Med 2019: 5015824.

107. Ma Z, Fan Y, Wu Y, Kebebe D, Zhang B, et al. (2019) Traditional Chinese medicine-combination therapies utilizing nanotechnology-based targeted delivery systems: a new strategy for antitumor treatment. Int J Nanomedicine 14: 2029-2053.

108. So TH, Chan SK, Lee VH, Chen BZ, Kong FM, et al. (2019) Chinese Medicine in Cancer Treatment - How is it Practised in the East and the West? Clin Oncol (R Coll Radiol) 31(8): 578-588.

109. Gong Y, Xu Z, Jin C, Deng H, Wang Z, et al. (2018) Treatment of Advanced Non-small-Cell Lung Cancer with Qi-Nourishing Essence-Replenishing Chinese Herbal Medicine Combined with Chemotherapy. Biol Proced Online 20: 9.

110. Jiao L, Bi L, Lu Y, Wang Q, Gong Y, et al (2018) Cancer chemoprevention and therapy using chinese herbal medicine. Biol Proced Online 20: 1.

111. Yue GG, Lee JK, Chan BC, Kwok HF, Hoi SW, et al. (2018) An innovative anti-cancer Chinese herbal formula exhibited multi-targeted efficacies in metastatic breast cancer mouse model. Chin Med 13: 64.

112. Aghajanpour M, Nazer MR, Obeidavi Z, Akbari M, Ezati P, et al. (2017) Functional foods and their role in cancer prevention and health promotion: a comprehensive review. Am J Cancer Res 7(4): 740769.

113. Volpato M, Hull MA (2018) Omega-3 polyunsaturated fatty acids as adjuvant therapy of colorectal cancer. Cancer Metastasis Rev 37(2-3): 545-555.

114. Liu J, Abdelmagid SA, Pinelli CJ, Monk JM, Liddle DM, et al. (2018) Marine fish oil is more potent than plantbased $n-3$ polyunsaturated fatty acids in the prevention of mammary tumors. J Nutr Biochem 55: 41-52.

115. Pacheco BS, Dos Santos MAZ, Schultze E, Martins RM, Lund RG, et al. (2018) Cytotoxic Activity of Fatty Acids From Antarctic Macroalgae on the Growth of Human Breast Cancer Cells. Front Bioeng Biotechnol 6: 185 .

116. Teas J, Vena S, Cone DL, Irhimeh M (2013) The consumption of seaweed as a protective factor in the etiology of breast cancer: proof of principle. J Appl Phycol 25(3): 771-779.

117. Rocha DHA, Seca AML, Pinto DCGA (2018) Seaweed Secondary Metabolites In Vitro and In Vivo Anticancer Activity. Mar Drugs 16(11). 


\section{Advances in Pharmacology and Clinical Trials}

118. Shreadah MA, El Moneam NMA, Al-Assar SA, NabilAdam A (2018) Phytochemical and pharmacological screening of Sargassium vulgare from Suez Canal, Egypt. Food Sci Biotechnol 27(4): 963-979.

119. Shin SA, Moon SY, Kim WY, Paek SM, Park HH, et al. (2018) Structure-Based Classification and AntiCancer Effects of Plant Metabolites. Int J Mol Sci 19(9).

120. Bernardini G, Minetti M, Polizzotto G, Biazzo M, Santucci A, (2018) Pro-Apoptotic Activity of French Polynesian Padina pavonica Extract on Human Osteosarcoma Cells. Mar Drugs 16(12).

121. Stonik VA, Fedorov SN (2014) Marine low molecular weight natural products as potential cancer preventive compounds. Mar Drugs 12(2): 636-671.

122. Kooti W, Servatyari K, Behzadifar M, Asadi-Samani M, Sadeghi F, et al. (2017) Effective Medicinal Plant in Cancer Treatment, Part 2: Review Study. J Evid Based Complementary Altern Med 22(4): 982-995.

123. Wali AF, Majid S, Rasool S, Shehada SB, Abdulkareem SK, et al. (2019) Natural products against cancer: Review on phytochemicals from marine sources in preventing cancer. Saudi Pharmaceutical Journal 27(6): 767-777.

124. Shree TJ, Poompavai S, Begum SMFM, Gowrisree V, Hemalatha S, et al. (2019) Cancer-Fighting Phytochemicals: Another Look. J Nanomedine Biotherapeutic Discov 8: 162.

125. Smith RA, Andrews KS, Brooks D, Fedewa SA, Manassaram-Baptiste D, et al. (2017) Cancer screening in the United States, 2017: A review of current American Cancer Society guidelines and current issues in cancer screening. CA Cancer J Clin 67(2): 100-121.

126. Kim SK, Kalimuthu S (2014) Introduction to Anticancer Drugs from Marine Origine. In: Se-Kwon Kim. Handbook of Anticancer Drugs from Marine Origin Publisher.

127. Sun L, Yim WS, Fahey P, Wang S, Zhu X, et al (2019) Investigation on Advanced Non-Small-Cell Lung Cancer among Elderly Patients Treated with Chinese Herbal Medicine versus Chemotherapy: A Pooled Analysis of Individual Data. Evid Based Complement Alternat Med 2019: 1898345.
128. Abdelaziz HM, Elzoghby AO, Helmy MW, Samaha MW, Fang JY, et al (2019) Liquid crystalline assembly for potential combinatorial chemo-herbal drug delivery to lung cancer cells. Int J Nanomedicine 14: 499-517.

129. Blandin Knight S, Crosbie PA, Balata H, Chudziak J, Hussell T, et al. (2017) Progress and prospects of early detection in lung cancer. Open Biol 7(9).

130. Zappa C, Mousa SA (2016) Non-small cell lung cancer: current treatment and future advances. Transl Lung Cancer Res 5(3): 288-300.

131. Lin CK, Lin RT, Chen T, Zigler C, Wei Y, et al. (2019) A global perspective on coal-fired power plants and burden of lung cancer. Environ Health 18(1): 9.

132. Alberg AJ, Brock MV, Ford JG, Samet JM, Spivack SD (2013) Epidemiology of lung cancer: Diagnosis and management of lung cancer, 3rd ed: American College of Chest Physicians evidence-based clinical practice guidelines. Chest 143 (5): e1S-e29S.

133. Sulé-Suso J, Watson NA, van Pittius DG, Jegannathen A (2019) Striking lung cancer response to selfadministration of cannabidiol: A case report and literature review. SAGE Open Med Case Rep 7: $2050313 X 19832160$.

134. Myneni AA, Chang SC, Niu R, Liu L, Swanson MK, et al. (2016) Raw Garlic Consumption and Lung Cancer in a Chinese Population. Cancer Epidemiol Biomarkers Prev 25(4): 624-33.

135. Jin ZY, Wu M, Han RQ, Zhang XF, Wang XS, et al. (2013) Raw garlic consumption as a protective factor for lung cancer, a population-based case-control study in a Chinese population. Cancer Prev Res (Phila) 6(7): 711-718.

136. Lin Y, Cai L (2012) Environmental and dietary factors and lung cancer risk among Chinese women: a case-control study in southeast China. Nutr Cancer 64(4): 508-514.

137. Mohammad P, Nosratollah Z, Mohammad R, Abbas A, Javad R (2010) The inhibitory effect of Curcuma longa extract on telomerase activity in A549 lung cancer cell line. Afr J Biotechnol 9(6).

138. Valiahdi SM, Iranshahi M, Sahebkar A (2013) Cytotoxic activities of phytochemicals from Ferula species. Daru 21(1): 39. 


\section{Advances in Pharmacology and Clinical Trials}

139. Wu CY, Ke Y, Zeng YF, Zhang YW, Yu HJ (2017) Anticancer activity of Astragalus polysaccharide in human non-small cell lung cancer cells. Cancer Cell Int 17: 115

140. Guo L, Bai SP, Zhao L, Wang XH (2012) Astragalus polysaccharide injection integrated with vinorelbine and cisplatin for patients with advanced non-small cell lung cancer: effects on quality of life and survival. Med Oncol 29(3): 1656-1662.

141. McCulloch M, See C, Shu XJ, Broffman M, Kramer A, et al. (2006) Astragalus-based Chinese herbs and platinum-based chemotherapy for advanced nonsmall-cell lung cancer: meta-analysis of randomized trials. J Clin Oncol 24(3): 419-430.

142. Li H, Hung A, Li M, Yang AWH (2019) Fritillariae Thunbergii Bulbus: Traditional Uses, Phytochemistry, Pharmacodynamics, Pharmacokinetics and Toxicity. Int J Mol Sci 20(7).

143. Li T, Chen X, Chen X, Ma DL, Leung CH, et al. (2016) Platycodin $\mathrm{D}$ potentiates proliferation inhibition and apoptosis induction upon AKT inhibition via feedback blockade in non-small cell lung cancer cells. Sci Rep 6: 37997.

144. Yim NH, Hwang YH, Liang C, Ma JY (2016) A platycoside-rich fraction from the root of Platycodon grandiflorum enhances cell death in A549 human lung carcinoma cells via mainly AMPK/mTOR/AKT signal-mediated autophagy induction. J Ethnopharmacol 194: 1060-1068.

145. Jeon D, Kim SW, Kim HS (2019) Platycodin D, a bioactive component of Platycodon grandiflorum, induces cancer cell death associated with extreme vacuolation. Anim Cells Syst (Seoul) 23(2): 118-127.

146. Huang MY, Jiang XM, Xu YL, Yuan LW, Chen YC, et al. (2019) Platycodin D triggers the extracellular release of programed death Ligand-1 in lung cancer cells. Food Chem Toxicol 131: 110537.

147. Lee CT, Huang YW, Yang CH, Huang KS (2015) Drug delivery systems and combination therapy by using vinca alkaloids. Curr Top Med Chem 15(15): 1491500 .

148. Zhang Y, Yang SH, Guo XL (2017) New insights into Vinca alkaloids resistance mechanism and circumvention in lung cancer. Biomed Pharmacother 96: 659-666.
149. Tagliamento M, Genova C, Rossi G, Coco S, Rijavec E, et al. (2019) Microtubule-targeting agents in the treatment of non-small cell lung cancer: insights on new combination strategies and investigational compounds. Expert Opin Investig Drugs 28(6): 513523.

150. Gusella M, Pasini F, Caruso D, Barile C, Modena Y, et al. (2019) Clinical outcomes of oral metronomic vinorelbine in advanced non-small cell lung cancer: correlations with pharmacokinetics and MDR1 polymorphisms. Cancer Chemother Pharmacol 83(3): 493-500.

151. Jung YJ, Lee EH, Lee CG, Rhee KJ, Jung WS, et al. (2017) AKR1B10-inhibitory Selaginella tamariscina extract and amentoflavone decrease the growth of A549 human lung cancer cells in vitro and in vivo. J Ethnopharmacol 202: 78-84.

152. Yang SF, Chu SC, Liu SJ, Chen YC, Chang YZ, et al. (2007) Antimetastatic activities of Selaginella tamariscina (Beauv.) on lung cancer cells in vitro and in vivo. J Ethnopharmacol 110(3): 483-4879.

153. Le MH, Do TT, Hoang TH, Chau VM, Nguyen TD (2012) Toxicity and anticancer effects of an extract from Selaginella tamariscina on a mice model. Nat Prod Res 26(12): 1130-1134.

154. Magesh V, Durga Bhavani K, Senthilnathan $P$, Rajendran P, Sakthisekaran D, et al. (2009) In vivo protective effect of crocetin on benzo (a) pyreneinduced lung cancer in Swiss albino mice. Phytother Res 23(4): 533-539.

155. Samarghandian S, Borji A, Farahmand SK, Afshari R, Davoodi S (2013) Crocus sativus L. (saffron) stigma aqueous extract induces apoptosis in alveolar human lung cancer cells through caspase-dependent pathways activation. Biomed Res Int 2013: 417928.

156. Samarghandian S, Tavakkol Afshari J, Davoodi S (2011) Suppression of pulmonary tumor promotion and induction of apoptosis by Crocus sativus $\mathrm{L}$. extraction. Appl Biochem Biotechnol 164(2): 238247.

157. Zhong YJ, Shi F, Zheng XL, Wang Q, Yang L, et al. (2011) Crocetin induces cytotoxicity and enhances vincristine-induced cancer cell death via p53dependent and -independent mechanisms. Acta Pharmacol Sin 32(12): 1529-1536. 


\section{Advances in Pharmacology and Clinical Trials}

158. Bhandari PR (2015) Crocus sativus L. (saffron) for cancer chemoprevention: A mini review. J Tradit Complement Med 5(2): 81-87.

159. Lin YJ, Liang WM, Chen CJ, Tsang H, Chiou JS, et al. (2019) Network analysis and mechanisms of action of Chinese herb-related natural compounds in lung cancer cells. Phytomedicine 58: 152893.

160. Pajaniradje S, Mohankumar K, Pamidimukkala R, Subramanian S, Rajagopalan R (2014) Antiproliferative and apoptotic effects of Sesbania grandiflora leaves in human cancer cells. Biomed Res Int 2014: 474953.

161. Yang CJ, Huang YJ, Wang CY, Wang CS, Wang PH, et al. (2010) Antiproliferative and antitumorigenic activity of Toona sinensis leaf extracts in lung adenocarcinoma. J Med Food 13(1): 54-61.

162. Pinmai K, Chunlaratthanabhorn S, Ngamkitidechakul C, Soonthornchareon N, Hahnvajanawong C (2008) Synergistic growth inhibitory effects of Phyllanthus emblica and Terminalia bellerica extracts with conventional cytotoxic agents: doxorubicin and cisplatin against human hepatocellular carcinoma and lung cancer cells. World J Gastroenterol 14(10): 1491-1497.

163. Zhao T, Sun Q, Marques M, Witcher M (2015) Anticancer Properties of Phyllanthus emblica (Indian Gooseberry). Oxid Med Cell Longev 2015: 950890.

164. Basu T, Panja S, Ghate NB, Chaudhuri D, Mandal N. Antioxidant and antiproliferative effects of different solvent fractions from Terminalia belerica Roxb. Fruit on various cancer cells. Cytotechnology 69(2): 201216.

165. Hung JY, Wen CW, Hsu YL, Lin ES, Huang MS, et al. (2013) Subamolide a induces mitotic catastrophe accompanied by apoptosis in human lung cancer cells. Evid Based Complement Alternat Med 2013: 828143.

166. Li GX, Chen YK, Hou Z, Xiao H, Jin H, et al. (2010) Prooxidative activities and dose-response relationship of (-)-epigallocatechin-3-gallate in the inhibition of lung cancer cell growth: a comparative study in vivo and in vitro. Carcinogenesis 31(5): 902-910.

167. Metwaly AM, Lianlian Z, Luqi H, Deqiang D (2019) Black Ginseng and Its Saponins: Preparation, Phytochemistry and Pharmacological Effects. Molecules 24(10): E1856.
168. Rosière R, Berghmans T, De Vuyst P, Amighi K, Wauthoz N (2019) The Position of Inhaled Chemotherapy in the Care of Patients with Lung Tumors: Clinical Feasibility and Indications According to Recent Pharmaceutical Progresses. Cancers (Basel) 11(3): E329.

169. Verco J, Johnston W, Baltezor M, Kuehl PJ, Gigliotti A, et al. (2019) Pharmacokinetic Profile of Inhaled Submicron Particle Paclitaxel (NanoPac(®)) in a Rodent Model. J Aerosol Med Pulm Drug Deliv 32(2): 99-109.

170. Tan BL (2019) Norhaizan ME. Curcumin Combination Chemotherapy: The Implication and Efficacy in Cancer. Molecules 24(14): E2527.

171. Lwin Z, Riess JW, Gandara D. The continuing role of chemotherapy for advanced non-small cell lung cancer in the targeted therapy era. J Thorac Dis 5: S556-564.

172. Scitech Europa (2018) Inhaled chemotherapy: a promising solution to treat lung cancer. Health Research News.

173. Sapalidis K, Zarogoulidis P, Huang H, Bai C, Wen Y, et al. (2018) Inhaled Immunotherapy Administration for Lung Cancer; Efficient? Certainly Possible. J Cancer 9(6): 1121-1126.

174. Thafeni MA, Sayed Y, Motadi LR (2012) Euphorbia mauritanica and Kedrostis hirtella extracts can induce anti-proliferative activities in lung cancer cells. Mol Biol rep 39(12): 10785-10794.

175. Hsu HY, Hwang PA (2019) Clinical applications of fucoidan in translational medicine for adjuvant cancer therapy. Clin Transl Med 8(1): 15.

176. Van Weelden G, Bobiński M, Okła K, van Weelden WJ, et al. (2019) Fucoidan Structure and Activity in Relation to Anti-Cancer Mechanisms. Mar Drugs 17(1): E32.

177. Wang $Y$, Xing $M$, Cao Q Ji A, Liang H, et al. (2019) Biological Activities of Fucoidan and the Factors Mediating Its Therapeutic Effects: A Review of Recent Studies. Mar Drugs 17(3): E183.

178. Misra P, Singh S. Role of cytokines in combinatorial immunotherapeutics of non-small cell lung cancer through systems perspective. Cancer Med 8(5):19761995. 


\section{Advances in Pharmacology and Clinical Trials}

179. Ercolano G, De Cicco P, Ianaro A (2019) New Drugs from the Sea: Pro-Apoptotic Activity of Sponges and Algae Derived Compounds. Mar Drugs 17(1): E31.

180. Song J, Su H, Wang BL, Zhou YY, Guo LL (2014) Fish consumption and lung cancer risk: systematic review and meta-analysis. Nutr Cancer 66(4): 539-549.

181. Siu FM, Ma DL, Cheung YW, Lok CN, Yan K, et al. (2008) Proteomic and transcriptomic study on the action of a cytotoxic saponin (Polyphyllin D): induction of endoplasmic reticulum stress and mitochondria-mediated apoptotic pathways. Proteomics 8(15): 3105-3117.

182. Takezaki T, Inoue M, Kataoka H, Ikeda S, Yoshida M, et al. (2003) Diet and lung cancer risk from a 14-year population-based prospective study in Japan: with special reference to fish consumption. Nutr Cancer 45(2): 160-167.

183. Yang P, Cartwright C, Chan D, Ding J, Felix E, et al. (2014) Anticancer activity of fish oils against human lung cancer is associated with changes in formation of PGE2 and PGE3 and alteration of Akt phosphorylation. Mol Carcinog 53(7): 566-577.

184. Daniel CR, Cross AJ, Graubard BI, Hollenbeck AR, Park Y, et al. (2011) Prospective investigation of poultry and fish intake in relation to cancer risk. Cancer Prev Res (Phila) 4(11):1903-1911.

185. Sun Y, Li Z, Li J, Li Z, Han J (2016) A Healthy Dietary Pattern Reduces Lung Cancer Risk: A Systematic Review and Meta-Analysis. Nutrients 8(3): 134.

186. Elisia I, Cho B, Hay M, Li MY, Hofs E, et al. (2019) The effect of diet and exercise on tobacco carcinogeninduced lung cancer. Carcinogenesis 40(3): 448-460.

187. Alsharairi NA (2019) The Effects of Dietary Supplements on Asthma and Lung Cancer Risk in Smokers and Non-Smokers: A Review of the Literature. Nutrients 11(4): E725.

188. Middha $\mathrm{P}$, Weinstein SJ, Männistö S, Albanes D, Mondul AM (2019) $\beta$-Carotene Supplementation and Lung Cancer Incidence in the Alpha-Tocopherol, BetaCarotene Cancer Prevention Study: The Role of Tar and Nicotine. Nicotine Tob Res 21(8): 1045-1050.

189. Narita S, Saito E, Sawada N, Shimazu T, Yamaji T, et al. (2018) JPHC Study Group. Dietary consumption of antioxidant vitamins and subsequent lung cancer risk: The Japan Public Health Center-based prospective study. Int J Cancer 142(12): 2441-2460.

190. Sealock T, Sharma S (2019) Smoking Cessation. StatPearls.

191. Steliga MA, Yang P (2019) Integration of smoking cessation and lung cancer screening. Transl Lung Cancer Res 8(Suppl 1): S88-S94.

192. Taylor KL, Deros DE, Fallon S, Stephens J, Kim E, et al. (2019) Study protocol for a telephone-based smoking cessation randomized controlled trial in the lung cancer screening setting: The lung screening, tobacco, and health trial. Contemp Clin Trials 82: 2535 .

193. Robbins SL, Kumar V, Cotran RS (2010) Robbins and Cotran Pathologic Basis of Disease. Philadelphia.

194. Vakiti A, Mewawalla P (2019) Cancer, Acute Myeloid Leukemia (AML, Erythroid Leukemia, Myelodysplasia-Related Leukemia, BCR-ABL Chronic Leukemia. Stat Pearls.

195. Naik J, Themeli M, de Jong-Korlaar R, Ruiter RWJ, Yuan H, et al. (2019) CD38 as a therapeutic target for adult acute myeloid leukemia and T-cell acute lymphoblastic leukemia. Haematologica 104(3): e100-e103.

196. Bawazir A, Al-Zamel N, Amen A, Akiel MA, Alhawiti NM, Alshehri A, et al. (2019) The burden of leukemia in the Kingdom of Saudi Arabia: 15 years period (1999-2013). BMC Cancer 19(1): 703.

197. Dhall A, Zee BM, Yan F, Blanco MA (2019) Intersection of Epigenetic and Metabolic Regulation of Histone Modifications in Acute Myeloid Leukemia. Front Oncol 9: 432.

198. Medeiros BC, Chan SM, Daver NG, Jonas BA, Pollyea DA (2019) Optimizing survival outcomes with postremission therapy in acute myeloid leukemia. Am J Hematol 94(7): 803-811.

199. Murphy BR, Roth M, Kolb EA, Alonzo T, Gerbing R, et al. (2019) Development of acute lymphoblastic leukemia following treatment for acute myeloid leukemia in children with Down syndrome: A case report and retrospective review of Children's Oncology Group acute myeloid leukemia trials. Pediatr Blood Cancer 66(8): e27700. 


\section{Advances in Pharmacology and Clinical Trials}

200. Puckett Y, Chan O (2019) Cancer Acute Lymphocytic Leukemia (ALL). Stat Pearls.

201. Branford S, Kim DDH, Apperley JF, Eide CA, Mustjoki $S$, et al. (2019) International CML Foundation Genomics Alliance. Laying the foundation for genomically-based risk assessment in chronic myeloid leukemia. Leukemia 33(8): 1835-1850.

202. Franki R (2018) Report details financial burden of blood cancers. MDedge.

203. Rahimi Babasheikhali S, Rahgozar S, Mohammadi M (2019) Ginger extract has anti-leukemia and antidrug resistant effects on malignant cells. J Cancer Res Clin Oncol 145(8): 1987-1998.

204. Hwang D, Kim M, Park H, Jeong MI, Jung W, et al. (2019) Natural Products and Acute Myeloid Leukemia: A Review Highlighting Mechanisms of Action. Nutrients 11(5): E1010.

205. Bhargava S, Malhotra H, Rathore OS, Malhotra B, Sharma P, et al. (2015) Anti-leukemic activities of alcoholic extracts of two traditional Indian medicinal plants. Leuk Lymphoma 56(11): 3168-3182.

206. Yang C, Cai H, Meng X (2016) Polyphyllin D induces apoptosis and differentiation in K562 human leukemia cells. Int Immunopharmacol 36:17-22.

207. Wu L, Li Q Liu Y (2014) Polyphyllin D induces apoptosis in K562/A02 cells through G2/M phase arrest. J Pharm Pharmacol 66(5): 713-721.

208. Turrini E, Calcabrini C, Sestili P, Catanzaro E, de Gianni E, et al. (2016) Withania somnifera Induces Cytotoxic and Cytostatic Effects on Human $T$ Leukemia Cells. Toxins (Basel) 8(5): E147

209. Pires N, Gota V, Gulia A, Hingorani L, Agarwal M, et al. (2019) Safety and Pharmacokinetics of WithaferinA in advanced stage high grade Osteosarcoma: A phase I trial. J Ayurveda Integr Med.

210. Kim S, Yu JS, Lee JY, Choi SU, Lee J, et al. (2019) Cytotoxic Withanolides from the Roots of Indian Ginseng (Withania somnifera). J Nat Prod 82(4): 765773.

211. Li C, Dong L, Su R, Bi Y, Qing Y, et al. (2019) Homoharringtonine exhibits potent anti-tumor effect and modulates DNA epigenome in acute myeloid leukemia by targeting SP1/TET1/5hmC. Haematologica.
212. Zhang J, Geng H, Liu L, Zhang H (2019) Synergistic cytotoxicity of homoharringtonine and etoposide in acute myeloid leukemia cells involves disrupted antioxidant defense. Cancer Manag Res 11: 10231032.

213. Wu Z, Zhuang H, Yu Q, Zhang X, Jiang X, et al. (2019) Homoharringtonine Combined with the Heat Shock Protein 90 Inhibitor IPI504 in the Treatment of FLT3ITD Acute Myeloid Leukemia. Transl Oncol 12(6): 801-809.

214. Yakhni M, Briat A, El Guerrab A, Furtado L, Kwiatkowski F, et al. (2019) Homoharringtonine, an approved anti-leukemia drug, suppresses triple negative breast cancer growth through a rapid reduction of anti-apoptotic protein abundance. Am J Cancer Res 9(5): 1043-1060.

215. Huang S, Pan J, Jin J, Li C, Li X, et al. (2019) Abivertinib, a novel BTK inhibitor: Anti-Leukemia effects and synergistic efficacy with homoharringtonine in acute myeloid leukemia. Cancer Lett 461: 132-143.

216. Tan M, Zhang Q, Yuan X, Chen Y, Wu Y (2019) Synergistic killing effects of homoharringtonine and arsenic trioxide on acute myeloid leukemia stem cells and the underlying mechanisms. J Exp Clin Cancer Res 38(1): 308.

217. Chen P, Zhan W, Wang B, You P, Jin Q, et al. (2019) Homoharringtonine potentiates the antileukemic activity of arsenic trioxide against acute myeloid leukemia cells. Exp Cell Res 376(2): 114-123.

218. Chen XJ, Zhang WN, Chen B, Xi WD, Lu Y, et al. (2019) Homoharringtonine deregulates MYC transcriptional expression by directly binding NF- $\mathrm{KB}$ repressing factor. Proc Natl Acad Sci U S A 116(6): 2220-2225.

219. Lien le Q, Linh TM, Giang VH, Mai NC, Nhiem NX, et al. (2016) New naphthalene derivatives and isoquinoline alkaloids from Ancistrocladus cochinchinensis with their anti-proliferative activity on human cancer cells. Bioorg Med Chem Lett 26(16): 3913-3917.

220. Dantas BB, Faheina-Martins GV, Coulidiati TH, Bomfim CC, da Silva Dias C, et al. (2015) Effects of curine in HL-60 leukemic cells: cell cycle arrest and apoptosis induction 69(2): 218-223. 


\section{Advances in Pharmacology and Clinical Trials}

221. Chen LG, Su PJ, Tsai PW, Yang LL, Wang CC (2017) Intermedin $\mathrm{A}$, a New Labdane Diterpene Isolated from Alpinia intermedia, prolonged the Survival Time of P-388D1 Tumor-Bearing CDF1 Mice. Planta Med 83(1-02): 151-157.

222. Li DH, Li JY, Xue CM, Han T, Sai CM, et al. (2017) Antiproliferative Dimeric Aporphinoid Alkaloids from the Roots of Thalictrum cultratum. J Nat Prod 80(11): 2893-2904.

223. Lam NS, Long X, Wong JW, Griffin RC, Doery JCG (2019) Artemisinin and its derivatives: a potential treatment for leukemia. Anticancer Drugs 30(1): 118.

224. Beck J, Schwarzer A, Gläser D, Mügge LO, Uhlig J, et al. (2017) Lenalidomide in combination with bendamustine and prednisolone in relapsed/refractory multiple myeloma: results of a phase 2 clinical trial (OSHO-\#077). J Cancer Res Clin Oncol 143(12): 2545-2553.

225. Drenberg CD, Buaboonnam J, Orwick SJ, Hu S, Li L, et al. (2016) Evaluation of artemisinins for the treatment of acute myeloid leukemia. Cancer Chemother Pharmacol 77(6):1231-1243.

226. Letis AS, Seo EJ, Nikolaropoulos SS, Efferth T, Giannis A, et al. (2017) Synthesis and cytotoxic activity of new artemisinin hybrid molecules against human leukemia cells. Bioorg Med Chem 25(13): 3357-3367.

227. Houh YK, Kim KE, Park S, Hur DY, Kim S, et al. (2017) The Effects of Artemisinin on the Cytolytic Activity of Natural Killer (NK) Cells. Int J Mol Sci 18(7): E1600.

228. Jiang HY, Wang CF, Fan L, Yang K, Feng JB, et al. (2013) Cytotoxic constituents from the stems of Clausena lansium (Lour.) Skeels. Molecules 18(9): 10768-10775.

229. Kim SP, Kang MY, Choi YH, Kim JH, Nam SH, et al. (2011) Mechanism of Hericium erinaceus (Yamabushitake) mushroom-induced apoptosis of U937 human monocytic leukemia cells. Food Funct 2(6): 348-56.

230. Nomura M, Takahashi T, Uesugi A, Tanaka R, Kobayashi S. Inotodiol, a lanostane triterpenoid, from Inonotus obliquus inhibits cell proliferation through caspase-3-dependent apoptosis. Anticancer Res 28(5A): 2691-2696.
231. Bayan L, Koulivand PH, Gorji A (2014) Garlic: a review of potential therapeutic effects. Avicenna J Phytomed 4(1): 1-14.

232. Antlsperger DS, Dirsch VM, Ferreira D, Su JL, Kuo ML, et al. (2003) Ajoene-induced cell death in human promyeloleukemic cells does not require JNK but is amplified by the inhibition of ERK. Oncogene 22(4): 582-589.

233. Zhang G, Gao X, Zeng H, Li Y, Guo X (2018) Virosecurinine induces apoptosis in human leukemia THP-1 cells and other underlying molecular mechanisms. Oncol Lett 15(1): 849-854.

234. Zhang G, Li M, Han S, Chen D, Wang Y, et al. (2014) Induction of human chronic myeloid leukemia K562 cell apoptosis by virosecurinine and its molecular mechanism. Mol Med Rep 10(5): 2365-2371.

235. Yang J, Chen L, Yan Y, Qiu J, Chen J, et al. (2019) BW18, a C-21 steroidal glycoside, exerts an excellent anti-leukemia activity through inducing $\mathrm{S}$ phase cell cycle arrest and apoptosis via MAPK pathway in K562 cells. Biomed Pharmacother 112: 108603.

236. Larasati YA, Yoneda-Kato N, Nakamae I, Yokoyama T, Meiyanto E, et al. (2018) Curcumin targets multiple enzymes involved in the ROS metabolic pathway to suppress tumor cell growth. Sci Rep 8(1): 2039.

237. Kouhpeikar H, Butler AE, Bamian F, Barreto GE, Majeed M, et al. (2019) Curcumin as a therapeutic agent in leukemia. J Cell Physiol 234(8):12404-12414.

238. Kujundžić RN, Stepanić V, Milković L, Gašparović AČ, Tomljanović M, et al. (2019) Curcumin and its Potential for Systemic Targeting of Inflamm-Aging and Metabolic Reprogramming in Cancer. Int J Mol Sci 20(5): E1180.

239. Santana-Bejarano UF, Bobadilla-Morales L, Mendoza-Maldonado L, Torres-Anguiano E, BrukmanJiménez SA, et al. (2019) In vitro effect of curcumin in combination with chemotherapy drugs in $\mathrm{Ph}(+)$ acute lymphoblastic leukemia cells. Oncol Lett 17(6): 52245240.

240. Henry D, Brumaire S, Hu X (2019) Involvement of pRb-E2F pathway in green tea extract-induced growth inhibition of human myeloid leukemia cells. Leuk Res 77: 34-41.

241. Iwasaki R, Ito K, Ishida T, Hamanoue $\mathrm{M}$, Adachi $\mathrm{S}$, et al. (2009) Catechin, green tea component, causes 


\section{Advances in Pharmacology and Clinical Trials}

caspase-independent necrosis-like cell death in chronic myelogenous leukemia. Cancer Sci 100(2): 349-56.

242. Marjanovic G (2017) The use of inexpensive broad spectrum lower toxicity therapeutics in chronic lymphocytic leukemia. J BUON 22(2): 288-294.

243. Yang CS, Wang H (2013) Cancer therapy combination: green tea and a phosphodiesterase 5 inhibitor? J Clin Invest 123(2): 556-558.

244. Yang CS, Wang H (2016) Cancer Preventive Activities of Tea Catechins. Molecules 21(12): E1679.

245. Angelo LS, Kurzrock R (2009) Turmeric and green tea: a recipe for the treatment of $\mathrm{B}$-chronic lymphocytic leukemia. Clin Cancer Res 15(4): 11231125.

246. Shanafelt TD, Call TG, Zent CS, Leis JF, LaPlant B, et al. (2013) Phase 2 trial of daily, oral Polyphenon E in patients with asymptomatic, Rai stage 0 to II chronic lymphocytic leukemia. Cancer 119(2): 363-370.

247. Smith DM, Dou QP (2001) Green tea polyphenol epigallocatechin inhibits DNA replication and consequently induces leukemia cell apoptosis. Int J Mol Med 7(6): 645-652.

248. Lee YK, Bone ND, Strege AK, Shanafelt TD, Jelinek DF, et al. (2004) VEGF receptor phosphorylation status and apoptosis is modulated by a green tea component, epigallocatechin-3-gallate (EGCG), in Bcell chronic lymphocytic leukemia. Blood 104(3): 788-794.

249. Gao N, Budhraja A, Cheng S, Yao H, Zhang Z, et al. (2009) Induction of apoptosis in human leukemia cells by grape seed extract occurs via activation of cJun NH2-terminal kinase. Clin Cancer Res 15(1): 140149.

250. Saedi TA, Md Noor S, Ismail P, Othman F (2014) The effects of herbs and fruits on leukaemia. Evid Based Complement Alternat Med 2014: 494136.

251. Espino J, González-Gómez D, Moreno D, FernándezLeón MF, Rodríguez AB, et al. (2013) Tempranilloderived grape seed extract induces apoptotic cell death and cell growth arrest in human promyelocytic leukemia HL-60 cells. Food Funct 4(12): 1759-66.

252. Al-Asady AAB, Algarmavy HMS, Salih SKM (2017) Antileukemic Effect of Polyphenol of Local Grape
Seeds Extract from Duhok/Kurdistan of Iraq: in vitro Study. Research in Cell Biology 3(1): 1-6.

253. Cao WJ, Wu K, Wang C, Wan DM (2016) Polydatininduced cell apoptosis and cell cycle arrest are potentiated by Janus kinase 2 inhibition in leukemia cells. Mol Med Rep 13(4): 3297-302.

254. Papandreou I, Verras M, McNeil B, Koong AC, Denko NC (2015) Plant stilbenes induce endoplasmic reticulum stress and their anti-cancer activity can be enhanced by inhibitors of autophagy. Exp Cell Res 339(1): 147-53.

255. Frazzi R, Guardi M (2017) Cellular and Molecular Targets of Resveratrol on Lymphoma and Leukemia Cells. Molecules 22(6).

256. Hu H, Qin YM (2006) Grape seed proanthocyanidin extract induced mitochondria-associated apoptosis in human acute myeloid leukaemia 14.3D10 cells. Chin Med J (Engl) 119(5): 417-421.

257. Dahlawi H, Jordan-Mahy N, Clench M, McDougall GJ, Maitre CL (2013) Polyphenols are responsible for the proapoptotic properties of pomegranate juice on leukemia cell lines. Food Sci Nutr 1(2): 196-208.

258. Kawaii S, Lansky EP (2004) Differentiationpromoting activity of pomegranate (Punica granatum) fruit extracts in HL-60 human promyelocytic leukemia cells. J Med Food 7(1): 13-8.

259. Asmaa MJ, Ali AJ, Farid JM, Azman S (2015) Growth inhibitory effects of crude pomegranate peel extract on chronic myeloid leukemia, K562 cells. Int J Appl Basic Med Res 5(2): 100-5.

260. Dahlawi H, Jordan-Mahy N, Clench MR, Le Maitre CL (2012) Bioactive actions of pomegranate fruit extracts on leukemia cell lines in vitro hold promise for new therapeutic agents for leukemia. Nutr Cancer 64(1):100-10.

261. Joseph MM, Aravind SR, Varghese S, Mini S, Sreelekha TT (2012) Evaluation of antioxidant, antitumor and immunomodulatory properties of polysaccharide isolated from fruit rind of Punica granatum. Mol Med Rep 5(2): 489-96.

262. Choi YJ, Yoon JH, Cha SW, Lee SG (2011) Ginsenoside Rh1 inhibits the invasion and migration of THP-1 acute monocytic leukemia cells via inactivation of the MAPK signaling pathway. Fitoterapia 82(6): 911-919. 


\section{Advances in Pharmacology and Clinical Trials}

263. Cho SH, Chung KS, Choi JH, Kim DH, Lee KT (2009) Compound $\mathrm{K}$, a metabolite of ginseng saponin, induces apoptosis via caspase-8-dependent pathway in HL-60 human leukemia cells. BMC Cancer 9: 449.

264. Chen Y, Xu Y, Zhu Y, Li X (2013) Anti-cancer effects of ginsenoside compound $\mathrm{k}$ on pediatric acute myeloid leukemia cells. Cancer Cell Int 13(1): 24.

265. Park JG, Son YJ, Aravinthan A, Kim JH, Cho JY (2016) Korean Red Ginseng water extract arrests growth of xenografted lymphoma cells. J Ginseng Res 40(4): 431-436.

266. Park SE, Park C, Kim SH, Hossain MA, Kim MY (2009) Korean red ginseng extract induces apoptosis and decreases telomerase activity in human leukemia cells. J Ethnopharmacol 121(2): 304-12.

267. Ardalani H, Avan A, Ghayour-Mobarhan M (2017) Podophyllotoxin: a novel potential natural anticancer agent. Avicenna J Phytomed 7(4): 285-294.

268. Yusenko M, Jakobs A, Klempnauer KH (2018) A novel cell-based screening assay for small-molecule MYB inhibitors identifies podophyllotoxins teniposide and etoposide as inhibitors of MYB activity. Sci Rep 8(1): 13159.

269. Cao B, Yang S, Li W, Chen H, Chen Y (2018) GMZ-1 is a podophyllotoxin derivative that suppresses growth and induces apoptosis in adriamycin-resistant K562/A02 cells through modulation of MDR1 expression. Mol Med Rep. 17(1): 474-478.

270. Silveira AL, Faheina-Martins GV, Maia RC, Araújo DA (2014) Compound A398, a novel podophyllotoxin analogue: cytotoxicity and induction of apoptosis in human leukemia cells. PLoS One 9(9): e107404.

271. Illiano M, Conte M, Sapio L, Nebbioso A, Spina A (2018) Forskolin Sensitizes Human Acute Myeloid Leukemia Cells to H3K27me2/3 Demethylases GSKJ4 Inhibitor via Protein Kinase A. Front Pharmacol 9: 792.

272. Hodroj MH, Jardaly A, Abi Raad S, Zouein A, Rizk S (2018) Andrographolide potentiates the antitumor effect of topotecan in acute myeloid leukemia cells through an intrinsic apoptotic pathway. Cancer Manag Res 10: 1079-1088.

273. Yang T, Yao S, Zhang X, Guo Y (2016) Andrographolide inhibits growth of human T-cell acute lymphoblastic leukemia Jurkat cells by downregulation of PI3K/AKT and upregulation of p38 MAPK pathways. Drug Des Devel Ther 10: 1389-97.

274. Sarkar S, Gopal PK, Paul S (2018) Andrographolide Induced Apoptosis in NALM-6 Cells Mediated Through the Cell Cycle Arrest and Nuclear Fragmentation. Pharmacog J 10(2): 210-214.

275. Cheung HY, Cheung SH, Li J, Cheung CS, Lai WP, et al. (2005) Andrographolide isolated from Andrographis paniculata induces cell cycle arrest and mitochondrial-mediated apoptosis in human leukemic HL-60 cells. Planta Med 71(12): 1106-1111.

276. Liao HC, Chou YJ, Lin CC, Liu SH, Oswita A, et al. (2019) Andrographolide and its potent derivative exhibit anticancer effects against imatinib-resistant chronic myeloid leukemia cells by downregulating the Bcr-Abl oncoprotein. Biochem Pharmacol 163: 308-320.

277. Manikam SD, Stanslas J (2009) Andrographolide inhibits growth of acute promyelocytic leukaemia cells by inducing retinoic acid receptor-independent cell differentiation and apoptosis. J Pharm Pharmacol 61(1): 69-78.

278. Chen X, Zhang J, Yuan L, Lay Y, Wong YK, et al. (2017) Andrographolide Suppresses MV4-11 Cell Proliferation through the Inhibition of FLT3 Signaling, Fatty Acid Synthesis and Cellular Iron Uptake. Molecules 22(9).

279. Chatterjee K, AlSharif D, Mazza C, Syar P, Al Sharif M, et al. (2018) Resveratrol and Pterostilbene Exhibit Anticancer Properties Involving the Downregulation of HPV Oncoprotein E6 in Cervical Cancer Cells. Nutrients 10(2).

280. Ramezani G, Pourgheysari B, Shirzad H, Sourani Z (2019) Pterostilbene increases Fas expression in Tlymphoblastic leukemia cell lines. Res Pharm Sci 14(1): 55-63.

281. McGill CM, Brown TJ, Cheng YY, Fisher LN, Shanmugavelandy SS, et al. (2018)Therapeutic Effect of Blueberry Extracts for Acute Myeloid Leukemia. Int J Biopharm Sci 1(1).

282. McGill CM, Brown TJ, Fisher LN, Gustafson SJ, Dunlap KL, et al. (2018) Combinatorial Efficacy of Quercitin and Nanoliposomal Ceramide for Acute Myeloid Leukemia. Int J Biopharm Sci 1(1). 


\section{Advances in Pharmacology and Clinical Trials}

283. Liu Z, Li F, Zhang B, Li S, Wu J, et al. (2015) Structural basis of plant homeodomain finger 6 (PHF6) recognition by the retinoblastoma binding protein 4 (RBBP4) component of the nucleosome remodeling and deacetylase (NuRD) complex. J Biol Chem 290(10): 6630-6638.

284. Van Vlierberghe P, Patel J, Abdel-Wahab O, Lobry C, Hedvat CV, et al. (2011) PHF6 mutations in adult acute myeloid leukemia. Leukemia 25(1): 130-134.

285. Ge Z, Gu Y, Han Q, Sloane J, Ge Q, et al. (2018) Plant homeodomain finger protein 2 as a novel IKAROS target in acute lymphoblastic leukemia. Epigenomics 10(1): 59-69.

286. Wendorff AA, Quinn SA, Rashkovan M, Madubata CJ, Ambesi-Impiombato A, et al. (2019) Phf6 Loss Enhances HSC Self-Renewal Driving Tumor Initiation and Leukemia Stem Cell Activity in T-ALL. Cancer Discov 9(3): 436-451.

287. Sarkar MK, Vadivel V, Raja MRC, Kar Mahapatra S (2019) Investigation of phytochemical constituents of anti-leukemic herbal drugs used by the traditional healers of Purulia, Birbhum and Bankura districts of West Bengal. Nat Prod Res 1-6.

288. Danışman Kalındemirtaş F, Birman H, Candöken E, Bilgiş Gazioğlu S, Melikoğlu G, et al. (2019) Cytotoxic Effects of Some Flavonoids and Imatinib on the K562 Chronic Myeloid Leukemia Cell Line: Data Analysis Using the Combination Index Method. Balkan Med J 36(2): 96-105.

289. Wei C, Xiao Q, Kuang X, Zhang T, Yang Z, et al. (2015) Fucoidan inhibits proliferation of the SKM-1 acute myeloid leukaemia cell line via the activation of apoptotic pathways and production of reactive oxygen species. Mol Med Rep 12(5): 6649-6655.

290. Park HS, Hwang HJ, Kim GY, Cha HJ, Kim WJ, et al. (2013) Induction of apoptosis by fucoidan in human leukemia U937 cells through activation of p38 MAPK and modulation of Bcl-2 family. Mar Drugs 11(7): 2347-2364.

291. Atashrazm F, Lowenthal RM, Woods GM, Holloway AF, Karpiniec SS, et al. (2016) Fucoidan Suppresses the Growth of Human Acute Promyelocytic Leukemia Cells In Vitro and In Vivo. J Cell Physiol 231(3): 688697.

292. Atashrazm F, Lowenthal RM, Dickinson JL, Holloway AF, Woods GM (2016) Fucoidan enhances the therapeutic potential of arsenic trioxide and all-trans retinoic acid in acute promyelocytic leukemia, in vitro and in vivo. Oncotarget 7(29): 46028-46041.

293. Rengarajan T, Rajendran $\mathrm{P}$, Nandakumar N, Balasubramanian MP, Nishigaki I (2013) Cancer preventive efficacy of marine carotenoid fucoxanthin: cell cycle arrest and apoptosis. Nutrients. 2013 Dec 6;5(12): 4978-89.

294. Kumar SR, Hosokawa M, Miyashita K (2013) Fucoxanthin: a marine carotenoid exerting anticancer effects by affecting multiple mechanisms. Mar Drugs 11(12): 5130-5147.

295. Catarino MD, Silva AMS, Cardoso SM (2018) Phycochemical Constituents and Biological Activities of Fucus spp. Mar Drug 16(8).

296. Almeida TP, Ferreira J, Vettorazzi A, Azqueta A, Rocha E, et al. (2018) Cytotoxic activity of fucoxanthin, alone and in combination with the cancer drugs imatinib and doxorubicin, in CML cell lines. Environ Toxicol Pharmacol 59: 24-33.

297. Almeida TP, Ramos AA, Ferreira J, Azqueta A, Rocha E (2019) Bioactive Compounds from Seaweed with Anti-Leukemic Activity: A Mini-Review on Carotenoids and Phlorotannins. Mini Rev Med Chem.

298. Saikia M, Retnakumari AP, Anwar S, Anto NP, Mittal $\mathrm{R}$, et al. (2018) Heteronemin, a marine natural product, sensitizes acute myeloid leukemia cells towards cytarabine chemotherapy by regulating farnesylation of Ras. Oncotarget 9(26):18115-18127.

299. Esmaeilbeig M, Kouhpayeh SA, Amirghofran Z (2015) An Investigation of the Growth Inhibitory Capacity of Several Medicinal Plants From Iran on Tumor Cell Lines. Iran J Cancer Prev 8(5): e4032.

300. Och M, Och A, Cieśla $Ł$, Kubrak T, Pecio $Ł$, et al. (2015) Study of cytotoxic activity, podophyllotoxin, and deoxypodophyllotoxin content in selected Juniperus species cultivated in Poland. Pharm Biol 53(6): 831-7.

301. Erfani N, Nazemosadat Z, Moein M (2015) Cytotoxic activity of ten algae from the Persian Gulf and Oman Sea on human breast cancer cell lines; MDA-MB-231, MCF-7, and T-47D. Pharmacognosy Res 7(2):133-137.

302. Joseph OA (2016) The prospects of medicinal plants in the treatment of breast cancer. European Pharmaceutical Review. 


\section{Advances in Pharmacology and Clinical Trials}

303. Azubuike SO, Muirhead C, Hayes L, McNally R (2018) Rising global burden of breast cancer: the case of subSaharan Africa (with emphasis on Nigeria) and implications for regional development: a review. World J Surg Oncol 16(1): 63.

304. Blumen H, Fitch K, Polkus V (2016) Comparison of Treatment Costs for Breast Cancer, by Tumor Stage and Type of Service. Am Health Drug Benefits 9(1): 23-32.

305. Alkabban FM, Ferguson T (2019) Cancer, Breast. StatPearls.

306. Mehrgou A, Akouchekian M. The importance of BRCA1 and BRCA2 genes mutations in breast cancer development. Med J Islam Repub Iran 30: 369.

307. Poehls UG, Hack CC, Wunderle M, Renner SP, Lux MP, et al. (2019) Awareness of breast cancer incidence and risk factors among healthy women in Germany: an update after 10 years. Eur J Cancer Prev 28(6): 515-521.

308. Hendrick RE, Baker JA, Helvie MA. Breast cancer deaths averted over 3 decades. Cancer 125(9): 1482 1488.

309. Vishwakarma G, Ndetan H, Das DN, Gupta G, Suryavanshi M, et al. (2019) Reproductive factors and breast cancer risk: A meta-analysis of case-control studies in Indian women. South Asian J Cancer 8(2): 80-84.

310. Ng HS, Vitry A, Koczwara B, Roder D, McBride ML (2019) Patterns of comorbidities in women with breast cancer: a Canadian population-based study. Cancer Causes Control 30(9): 931-941.

311. Bahri N, Fathi Najafi T, Homaei Shandiz F, Tohidinik HR, Khajavi A (2019) The relation between stressful life events and breast cancer: a systematic review and meta-analysis of cohort studies. Breast Cancer Res Treat 176(1): 53-61.

312. Ho-Huynh A, Tran A, Bray G, Abbot S, Elston T, et al. ( Factors influencing breast cancer outcomes in Australia: A systematic review. Eur J Cancer Care (Engl) 28(4): e13038.

313. Feng Y, Spezia M, Huang S, Yuan C, Zeng Z, et al. (2018) Breast cancer development and progression: Risk factors, cancer stem cells, signaling pathways, genomics, and molecular pathogenesis. Genes Dis 5(2): 77-106.
314. Sun YS, Zhao Z, Yang ZN, Xu F, Lu HJ, et al. (2017) Risk Factors and Preventions of Breast Cancer. Int J Biol Sci 13(11): 1387-1397.

315. (IQWiG) (2006) Cologne, Germany: Risk factors for breast cancer.

316. Alexander A, Kaluve R, Prabhu JS, Korlimarla A, Srinath BS, et al. (2019) The Impact of Breast Cancer on the Patient and the Family in Indian Perspective. Indian J Palliat Care 25(1): 66-72.

317. Chen L, Malone KE, Li CI (2014) Bra wearing not associated with breast cancer risk: a populationbased case-control study. Cancer Epidemiol Biomarkers Prev 23(10): 2181-2185.

318. Rios SSD, Chen ACR, Chen JR, Filho CMC, Amorim TS, et al. (2016) Wearing a Tight Bra for many hours a day is associated with increased risk of breast cancer. Adv Oncol Res Treat 1(1): 1-5.

319. Virani S, Chindaprasirt J, Wirasorn K, Sookprasert A, Somintara O, et al. (2018) Breast Cancer Incidence Trends and Projections in Northeastern Thailand. J Epidemiol 28(7): 323-330.

320. Yabroff KR, Lund J, Kepka D, Mariotto A (2011) Economic burden of cancer in the United States: estimates, projections, and future research. Cancer Epidemiol Biomarkers Prev 20(10): 2006-2014.

321. Mariotto AB, Yabroff KR, Shao Y, Feuer EJ, Brown ML (2011) Projections of the cost of cancer care in the United States: 2010-2020. J Natl Cancer Inst 103(2): 117-128.

322. Iadeluca L, Mardekian J, Chander P, Hopps M, Makinson GT (2017) The burden of selected cancers in the US: health behaviors and health care resource utilization. Cancer Manag Res 9: 721-730.

323. Montecucco A, Zanetta F, Biamonti G (2015) Molecular mechanisms of etoposide. EXCLI J 14: 95108.

324. Benzina S, Harquail J, Jean S, Beauregard AP, Colquhoun CD, et al. (2015) Robichaud GA. Deoxypodophyllotoxin isolated from Juniperus communis induces apoptosis in breast cancer cells. Anticancer Agents Med Chem 15(1): 79-88.

325. Khaled M, Belaaloui G, Jiang ZZ, Zhu X, Zhang LY (2016) Antitumor effect of Deoxypodophyllotoxin on human breast cancer xenograft transplanted in 


\section{Advances in Pharmacology and Clinical Trials}

BALB/c nude mice model. J Infect Chemother 22(10): 692-696.

326. Guerram M, Jiang ZZ, Sun L, Zhu X, Zhang LY (2015) Antineoplastic effects of deoxypodophyllotoxin, a potent cytotoxic agent of plant origin, on glioblastoma U-87 MG and SF126 cells. Pharmacol Rep 67(2): 245252.

327. Zang X, Wang G, Cai Q, Zheng X, Zhang J, et al. (2018) A Promising Microtubule Inhibitor Deoxypodophyllotoxin Exhibits Better Efficacy to Multidrug-Resistant Breast Cancer than Paclitaxel via Avoiding Efflux Transport. Drug Metab Dispos 46(5): 542-551.

328. Van Slambrouck S, Daniels AL, Hooten CJ, Brock SL, Jenkins AR, et al. (2007) Effects of crude aqueous medicinal plant extracts on growth and invasion of breast cancer cells. Oncol Rep 17(6): 1487-1492.

329. Kamata H, Sadahiro S, Yamori T (2019) Discovery of Inhibitors of Membrane Traffic from a Panel of Clinically Effective Anticancer Drugs. Biol Pharm Bull 42(5): 814-818.

330. Mavrogiannis AV, Kokkinopoulou I, Kontos CK, Sideris DC (2018) Effect of Vinca Alkaloids on the Expression Levels of microRNAs Targeting Apoptosisrelated Genes in Breast Cancer Cell Lines. Curr Pharm Biotechnol 19(13): 1076-1086.

331. Wong MY, Chiu GN. Simultaneous liposomal delivery of quercetin and vincristine for enhanced estrogenreceptor-negative breast cancer treatment. Anticancer Drugs 21(4): 401-410.

332. Su M, Zhao M, Luo Y, Lin X, Xu L, et al. (2011) Evaluation of the efficacy, toxicity and safety of vinorelbine incorporated in a lipid emulsion. Int J Pharm 411(1-2): 188-196.

333. Ghersi D, Willson ML, Chan MM, Simes J, Donoghue E, et al. (2015) Taxane-containing regimens for metastatic breast cancer. Cochrane Database Syst Rev 6: CD003366.

334. Bachegowda LS, Makower DF, Sparano JA (2014) Taxanes: impact on breast cancer therapy. Anticancer Drugs 25(5): 512-521.

335. Alken S, Kelly CM (2013) Benefit risk assessment and update on the use of docetaxel in the management of breast cancer. Cancer Manag Res 5: 357-365.
336. Habib S, Delourme J, Dhalluin X, Petyt G, Tacelli N, et al. (2013) Bevacizumab and weekly paclitaxel for non-squamous non small cell lung cancer patients: a retrospective study. Lung Cancer 80(2): 197-202.

337. Joris S, Fontaine C, Decoster L, Vanacker L, Schallier D, et al. (2019) Retrospective comparison of two consecutive cohorts of adjuvant chemotherapy regimens of cyclophosphamide with either docetaxel or paclitaxel in older patients with early breast cancer. Breast J 25(4): 663-666.

338. Liu Y, Xu Z, Zhang Z, Wen G, Sun J, et al. (2019) Efficacy and safety of TE/TEC/intensive paclitaxel neoadjuvant chemotherapy for the treatment of breast cancer. Oncol Lett 17(1): 907-912.

339. Bachelot T, Ciruelos E, Schneeweiss A, Puglisi F, Peretz-Yablonski T, et al. (2019) Preliminary safety and efficacy of first-line pertuzumab combined with trastuzumab and taxane therapy for HER2-positive locally recurrent or metastatic breast cancer (PERUSE). Ann Oncol 30(5): 766-773.

340. Nyrop KA, Deal AM, Reeder-Hayes KE, Shachar SS, Reeve BB, et al. (2019) Patient-reported and clinicianreported chemotherapy-induced peripheral neuropathy in patients with early breast cancer: Current clinical practice. Cancer 125(17): 2945-2954.

341. Hojo T, Masuda N, Iwamoto T, Niikura N, Anan K, et al. (2019) Taxane-based combinations as adjuvant chemotherapy for node-positive ER-positive breast cancer based on 2004-2009 data from the Breast Cancer Registry of the Japanese Breast Cancer Society. Breast Cancer.

342. Ntellas P, Spathas N, Agelaki S, Zintzaras E, Saloustros E (2019) Taxane \& cyclophosphamide vs anthracycline \& taxane-based chemotherapy as adjuvant treatment for breast cancer: a pooled analysis of randomized controlled trials by the Hellenic Academy of Oncology. Oncotarget 10(11): 1209-1216.

343. Kubatka P, Uramova S, Kello M, Kajo K, Kruzliak P, et al. (2017) Antineoplastic effects of clove buds (Syzygium aromaticum L.) in the model of breast carcinoma. J Cell Mol Med 21(11): 2837-2851.

344. Legault J, Pichette A (2007) Potentiating effect of beta-caryophyllene on anticancer activity of alphahumulene, isocaryophyllene and paclitaxel. J Pharm Pharmacol 59(12): 1643-1647. 


\section{Advances in Pharmacology and Clinical Trials}

345. Park KR, Nam D, Yun HM, Lee SG, Jang HJ, et al. (2011) $\beta$-Caryophyllene oxide inhibits growth and induces apoptosis through the suppression of $\mathrm{PI3K} / \mathrm{AKT} / \mathrm{mTOR} / \mathrm{S} 6 \mathrm{~K} 1$ pathways and ROS-mediated MAPKs activation. Cancer Lett 312(2): 178-88.

346. Kim C, Cho SK, Kapoor S, Kumar A, Vali S, Abbasi T, Kim SH, Sethi G, Ahn KS. $\beta$-Caryophyllene oxide inhibits constitutive and inducible STAT3 signaling pathway through induction of the SHP-1 protein tyrosine phosphatase. Mol Carcinog 53(10): 793-806.

347. Vidhya N, Devaraj SN (2011) Induction of apoptosis by eugenol in human breast cancer cells. Indian J Exp Biol 49(11): 871-878.

348. Sigurdsson S, Ogmundsdottir HM, Hallgrimsson J, Gudbjarnason S (2005) Antitumour activity of Angelica archangelica leaf extract. In Vivo 19(1): 191194.

349. Motaghed M, Al-Hassan FM, Hamid SS (2013) Cellular responses with thymoquinone treatment in human breast cancer cell line MCF-7. Pharmacognosy Res 5(3): 200-206.

350. Eggenschwiler J, von Balthazar L, Stritt B, Pruntsch D, Ramos M, et al. (2007) Mistletoe lectin is not the only cytotoxic component in fermented preparations of Viscum album from white fir (Abies pectinata). BMC Complement Altern Med.

351. Thronicke A, Oei SL, Merkle A, Matthes H, Schad F (2018) Clinical Safety of Combined Targeted and Viscum album L. Therapy in Oncological Patients. Medicines (Basel) 5(3): E100.

352. Weissenstein U, Kunz M, Urech K, Regueiro U, Baumgartner S. Interaction of a standardized mistletoe (Viscum album) preparation with antitumor effects of Trastuzumab in vitro. BMC Complement Altern Med 16: 271.

353. Beuth J, Ko HL, Schneider H, Tawadros S, Kasper HU, et al. (2006) Intratumoral application of standardized mistletoe extracts down regulates tumor weight via decreased cell proliferation, increased apoptosis and necrosis in a murine model. Anticancer Res 26(6B): 4451-4456.

354. Kienle GS, Glockmann A, Schink M, Kiene H (2009) Viscum album L. extracts in breast and gynaecological cancers: a systematic review of clinical and preclinical research. J Exp Clin Cancer Res 28: 79.
355. Harmsma M, Grommé M, Ummelen M, Dignef W, Tusenius KJ, et al. (2004) Differential effects of Viscum album extract IscadorQu on cell cycle progression and apoptosis in cancer cells. Int J Oncol 25(6): 1521-1529.

356. Tai CJ, Liu CH, Pan YC, Wong SH, Tai CJ, et al. (2019) Chemovirotherapeutic Treatment Using Camptothecin Enhances Oncolytic Measles VirusMediated Killing of Breast Cancer Cells 9(1): 6767.

357. Venditti A, Maggi F, Quassinti L, Bramucci M, Lupidi G, et al. (2018) Bioactive Constituents of Juniperus turbinata Guss. from La Maddalena Archipelago. Chem Biodivers 15(8): e1800148.

358. Ben Mrid R, Bouchmaa N, Bouargalne Y, Ramdan B, Karrouchi K, et al. (2019) Phytochemical Characterization, Antioxidant and In Vitro Cytotoxic Activity Evaluation of Juniperus oxycedrus Subsp. oxycedrus Needles and Berries. Molecules 24(3): E502.

359. Bayala B, Bassole IH, Scifo R, Gnoula C, Morel L, Lobaccaro JM, Simpore J. Anticancer activity of essential oils and their chemical components - a review. Am J Cancer Res 4(6): 591-607.

360. Wang Y, Sun H, Xiao Z, Zhang G, Zhang D, et al. (2018) DNA damage and apoptosis induced by a potent orally podophyllotoxin derivative in breast cancer. Cell Commun Signal 16(1): 52.

361. Zilla MK, Nayak D, Amin H, Nalli Y, Rah B, et al. (2014) 4'-Demethyl-deoxypodophyllotoxin glucoside isolated from Podophyllum hexandrum exhibits potential anticancer activities by altering Chk-2 signaling pathway in MCF-7 breast cancer cells. Chem Biol Interact 224: 100-107.

362. Mukund V, Saddala MS, Farran B, Mannavarapu M, Alam A, et al. (2019) Molecular docking studies of angiogenesis target protein HIF- $1 \alpha$ and genistein in breast cancer. Gene 701: 169-172.

363. Yu S, Zhu L, Wang K, Yan Y, He J, et al. (2019) Green tea consumption and risk of breast cancer: A systematic review and updated meta-analysis of casecontrol studies. Medicine (Baltimore) 98(27): e16147.

364. Stuart EC, Scandlyn MJ, Rosengren RJ (2006) Role of epigallocatechin gallate (EGCG) in the treatment of breast and prostate cancer. Life Sci 79(25): 23292336. 


\section{Advances in Pharmacology and Clinical Trials}

365. Samavat H, Wu AH, Ursin G, Torkelson CJ, Wang R, et al. (2019) Green Tea Catechin Extract Supplementation Does Not Influence Circulating Sex Hormones and Insulin-Like Growth Factor Axis Proteins in a Randomized Controlled Trial of Postmenopausal Women at High Risk of Breast Cancer. J Nutr 149(4): 619-627.

366. Khan N, Mukhtar H (2018) Tea Polyphenols in Promotion of Human Health. Nutrients 11(1): E39.

367. Schröder L, Marahrens P, Koch JG, Heidegger H, Vilsmeier T, et al. (2019) Effects of green tea, matcha tea and their components epigallocatechin gallate and quercetin on MCF-7 and MDA-MB-231 breast carcinoma cells. Oncol Rep 41(1): 387-396.

368. Zhang JY, Liao YH, Lin Y, Liu Q, Xie XM, et al. (2019) Effects of tea consumption and the interactions with lipids on breast cancer survival. Breast Cancer Res Treat 176(3): 679-686.

369. Najaf NM, Salehi M, Ghazanfarpour M, Hoseini ZS, Khadem-Rezaiyan M (2018) The association between green tea consumption and breast cancer risk: A systematic review and meta-analysis. Phytother Res 32(10):1855-1864.

370. Gianfredi V, Nucci D, Abalsamo A, Acito M, Villarini M, et al. (2018) Green Tea Consumption and Risk of Breast Cancer and Recurrence-A Systematic Review and Meta-Analysis of Observational Studies. Nutrients 10(12): E1886.

371. Cai ZY, Li XM, Liang JP, Xiang LP, Wang KR, et al. (2018) Bioavailability of Tea Catechins and Its Improvement. Molecules 23(9): E2346.

372. Iwasaki M, Mizusawa J, Kasuga Y, Yokoyama S, Onuma H, et al. (2013) Green tea consumption and breast cancer risk in Japanese women: a case-control study. Nutr Cancer 66(1): 57-67.

373. Shirakami Y, Shimizu M (2018) Possible Mechanisms of Green Tea and Its Constituents against Cancer. Molecules 23(9): E2284.

374. Sahin I, Bilir B, Ali S, Sahin K, Kucuk O (2019) Soy Isoflavones in Integrative Oncology: Increased Efficacy and Decreased Toxicity of Cancer Therapy. Integr Cancer Ther 18:1534735419835310.

375. Wu SY, Wu AT, Yuan KS, Liu SH (2016) Brown Seaweed Fucoidan Inhibits Cancer Progression by Dual Regulation of mir-29c/ADAM12 and miR-17-
5p/PTEN Axes in Human Breast Cancer Cells. J Cancer 7(15): 2408-2419.

376. Moussavou G, Kwak DH, Obiang-Obonou BW, Maranguy CA, Dinzouna-Boutamba SD, et al. (2014) Anticancer effects of different seaweeds on human colon and breast cancers. Mar Drugs 12(9): 48984911.

377. Montuori N, Pesapane A, Rossi FW, Giudice V, De Paulis A, et al. (2016) Urokinase type plasminogen activator receptor (UPAR) as a new therapeutic target in cancer. Transl Med UniSa 15: 15-21.

378. Teas J, Vena S, Cone DL, Irhimeh M (2013) The consumption of seaweed as a protective factor in the etiology of breast cancer: proof of principle. J Appl Phycol 25(3): 771-779.

379. Shamsabadi FT, Khoddami A, Fard SG, Abdullah R, Othman HH, et al. (2013) Comparison of tamoxifen with edible seaweed (Eucheuma cottonii L.) extract in suppressing breast tumor. Nutr Cancer 65(2): 255262.

380. Jazzara M, Ghannam A, Soukkarieh C, Murad H (2016) Anti-Proliferative Activity of $\lambda$-Carrageenan Through the Induction of Apoptosis in Human Breast Cancer Cells, Int J Cancer Manag 9(4): e3836.

381. Groult H, Cousin R, Chot-Plassot C, Maura M, Bridiau $\mathrm{N}$, et al. (2019) $\lambda$-Carrageenan Oligosaccharides of Distinct Anti-Heparanase and Anticoagulant Activities Inhibit MDA-MB-231 Breast Cancer Cell Migration. Mar Drugs 17(3): E140.

382. Losada-Echeberría M, Herranz-López M, Micol V, Barrajón-Catalán E (2017) Polyphenols as Promising Drugs against Main Breast Cancer Signatures. Antioxidants (Basel) 6(4): E88.

383. Namvar F, Mohamad R, Baharara J, Zafar-Balanejad S, Fargahi F, et al. (2013) Antioxidant, antiproliferative, and antiangiogenesis effects of polyphenol-rich seaweed (Sargassum muticum). Biomed Res Int 2013: 604787.

384. Niedzwiecki A, Roomi MW, Kalinovsky T, Rath M (2016) Anticancer Efficacy of Polyphenols and Their Combinations. Nutrients 8(9): E552.

385. Kapinova A, Kubatka P, Golubnitschaja 0, Kello M, et al. (2018) Dietary phytochemicals in breast cancer research: anticancer effects and potential utility for 


\section{Advances in Pharmacology and Clinical Trials}

effective chemoprevention. Environ Health Prev Med 23(1): 36 .

386. Keating E, Martel F (2018) Antimetabolic Effects of Polyphenols in Breast Cancer Cells: Focus on Glucose Uptake and Metabolism. Front Nutr 5: 25.

387. Sudhakaran M, Sardesai S, Doseff AI (2019) Flavonoids: New Frontier for Immuno-Regulation and Breast Cancer Control. Antioxidants (Basel) 8(4): E103.

388. Hui C, Qi X, Qianyong Z, Xiaoli P, Jundong Z, et al. (2013) Flavonoids, flavonoid subclasses and breast cancer risk: a meta-analysis of epidemiologic studies. PLoS One 8(1): e54318.

389. Sak K (2017) Epidemiological Evidences on Dietary Flavonoids and Breast Cancer Risk: A Narrative Review. Asian Pac J Cancer Prev 18(9): 2309-2328.

390. Takemura H, Sakakibara H, Yamazaki S, Shimoi K (2013) Breast cancer and flavonoids - a role in prevention. Curr Pharm Des 19(34): 6125-6132.

391. Batra P, Sharma AK (2013) Anti-cancer potential of flavonoids: recent trends and future perspectives. 3 Biotech 3(6): 439-459.

392. Magne Nde CB, Zingue S, Winter E, Creczynski-Pasa TB, Michel T, et al. (2015) Flavonoids, Breast Cancer Chemopreventive and/or Chemotherapeutic Agents. Curr Med Chem 22(30): 3434-346.

393. Abotaleb M, Samuel SM, Varghese E, Varghese S, Kubatka P, et al. (2018) Flavonoids in Cancer and Apoptosis. Cancers (Basel) 11(1): 28.

394. Pang BB, Chu YK, Yang H (2018) Anti-breast cancer mechanism of flavonoids. Zhongguo Zhong Yao Za Zhi 43(5): 913-920.

395. Zhang HW, Hu JJ, Fu RQ Liu X, Zhang YH, et al. (2018) Flavonoids inhibit cell proliferation and induce apoptosis and autophagy through downregulation of $\mathrm{PI} 3 \mathrm{~K} \gamma$ mediated $\mathrm{PI} 3 \mathrm{~K} / \mathrm{AKT} / \mathrm{mTOR} / \mathrm{p} 70 \mathrm{~S} 6 \mathrm{~K} / \mathrm{ULK}$ signaling pathway in human breast cancer cells. Sci Rep 8(1): 11255.

396. Rodríguez-García C, Sánchez-Quesada C, J Gaforio J (2019) Dietary Flavonoids as Cancer Chemopreventive Agents: An Updated Review of Human Studies. Antioxidants (Basel) 8(5): 137.
397. Abudabbus A, Badmus JA, Shalaweh S, Bauer R, Hiss D (2017) Effects of Fucoidan and Chemotherapeutic Agent Combinations on Malignant and Non-malignant Breast Cell Lines. Curr Pharm Biotechnol 18(9): 748757.

398. Zhang J, Riby JE, Conde L, Grizzle WE, Cui X, et al. (2016) A Fucus vesiculosus extract inhibits estrogen receptor activation and induces cell death in female cancer cell lines. BMC Complement Altern 16:151.

399. Moussavou G, Kwak DH, Obiang-Obonou BW, Maranguy CA, Dinzouna-Boutamba SD, et al. (2014) Anticancer effects of different seaweeds on human colon and breast cancers. Mar Drugs 12(9): 48984911.

400. Atashrazm F, Lowenthal RM, Woods GM, Holloway AF, Dickinson JL (2015) Fucoidan and cancer: a multifunctional molecule with anti-tumor potential. Mar Drugs 13(4): 2327-2346.

401. Lu J, Shi KK, Chen S, Wang J, Hassouna A, et al. (2018)Fucoidan Extracted from the New Zealand Undaria pinnatifida-Physicochemical Comparison against Five Other Fucoidans: Unique Low Molecular Weight Fraction Bioactivity in Breast Cancer Cell Lines. Mar Drugs 16(12): E461.

402. Zorofchian MS, Karimian H, Khanabdali R, Razavi M, Firoozinia M, et al. (2014) Anticancer and antitumor potential of fucoidan and fucoxanthin, two main metabolites isolated from brown algae. ScientificWorldJournal 2014: 768323.

403. Xue M, Ge Y, Zhang J, Wang Q, Hou L, et al. (2012) Anticancer properties and mechanisms of fucoidan on mouse breast cancer in vitro and in vivo. PLoS One 7(8): e43483.

404. Pawar VK, Singh Y, Sharma K, Shrivastav A, Sharma A, et al. (2019) Improved chemotherapy against breast cancer through immunotherapeutic activity of fucoidan decorated electrostatically assembled nanoparticles bearing doxorubicin. Int J Biol Macromol 122: 1100-1114.

405. He X, Xue M, Jiang S, Li W, Yu J, et al. (2019) Fucoidan Promotes Apoptosis and Inhibits EMT of Breast Cancer Cells. Biol Pharm Bull 42(3): 442-447.

406. Xue M, Ge Y, Zhang J, Liu Y, Wang Q Hou L, Zheng Z. Fucoidan inhibited 4T1 mouse breast cancer cell growth in vivo and in vitro via downregulation of Wnt/ $\beta$-catenin signaling. Nutr Cancer 65(3):460-468. 


\section{Advances in Pharmacology and Clinical Trials}

407. Xue M, Ji X, Liang H, Liu Y, Wang B, et al. (2018) The effect of fucoidan on intestinal flora and intestinal barrier function in rats with breast cancer. Food Funct 9(2): 1214-1223.

408. Oliveira C, Neves NM, Reis RL, Martins A, Silva TH. Gemcitabine delivered by fucoidan/chitosan nanoparticles presents increased toxicity over human breast cancer cells. Nanomedicine (Lond) 13(16): 2037-2050.

409. Gong X, Smith JR, Swanson HM, Rubin LP (2018) Carotenoid Lutein Selectively Inhibits Breast Cancer Cell Growth and Potentiates the Effect of Chemotherapeutic Agents through ROS-Mediated Mechanisms. Molecules 23(4): E905.

410. Chang J, Zhang Y, Li Y, Lu K, Shen Y, et al. (2018) $\mathrm{NrF} 2 / \mathrm{ARE}$ and NF- $\mathrm{KB}$ pathway regulation may be the mechanism for lutein inhibition of human breast cancer cell. Future Oncol 14(8): 719-726.

411. Mignone LI, Giovannucci E, Newcomb PA, TitusErnstoff L, Trentham-Dietz A, et al. (2009) Dietary carotenoids and the risk of invasive breast cancer. Int J Cancer 124(12): 2929-2937.

412. Li Y, Zhang Y, Liu X, Wang M, Wang P, et al. (2018) Lutein inhibits proliferation, invasion and migration of hypoxic breast cancer cells via downregulation of HES1. Int J Oncol 52(6): 2119-2129.

413. Yan B, Lu MS, Wang L, Mo XF, Luo WP, et al. (2016) Specific serum carotenoids are inversely associated with breast cancer risk among Chinese women: a case-control study. Br J Nutr 115(1): 129-137.

414. Rocha DHA, Seca AML, Pinto DCGA (2018) Seaweed Secondary Metabolites In Vitro and In Vivo Anticancer Activity. Mar Drugs 16(11): E410.

415. Erfani N, Nazemosadat Z, Moein M (2015) Cytotoxic activity of ten algae from the Persian Gulf and Oman Sea on human breast cancer cell lines; MDA-MB-231, MCF-7, and T-47D. Pharmacognosy Res 7(2):133-137.

416. Li YX, Himaya SW, Dewapriya P, Zhang C, Kim SK. Fumigaclavine $\mathrm{C}$ from a marine-derived fungus Aspergillus fumigatus induces apoptosis in MCF-7 breast cancer cells. Mar Drugs 11(12): 5063-5086.

417. Dyshlovoy SA, Honecker F (2015) Marine Compounds and Cancer: Where Do We Stand? Mar Drugs 13(9): 5657-5665.
418. Vaikundamoorthy R, Krishnamoorthy V, Vilwanathan R, Rajendran R (2018) Structural characterization and anticancer activity (MCF7 and MDA-MB-231) of polysaccharides fractionated from brown seaweed Sargassum wightii. Int J Biol Macromol 111: 1229-1237.

419. Sithranga Boopathy N, Kathiresan K (2010) Anticancer drugs from marine flora: an overview. J Oncol 2010: 214186.

420. Abd-Ellatef GF, Ahmed OM, Abdel-Reheim ES, AbdelHamid AZ (2017) Ulva lactuca polysaccharides prevent Wistar rat breast carcinogenesis through the augmentation of apoptosis, enhancement of antioxidant defense system, and suppression of inflammation. Breast Cancer (Dove Med Press) 9: 6783.

421. Fedorov SN, Ermakova SP, Zvyagintseva TN, Stonik VA (2013) Anticancer and cancer preventive properties of marine polysaccharides: some results and prospects. Mar Drugs 11(12): 4876-4901.

422. Ghannam A, Murad H, Jazzara M, Odeh A, Allaf AW (2018) Isolation, Structural characterization, and antiproliferative activity of phycocolloids from the red seaweed Laurencia papillosa on MCF-7 human breast cancer cells. Int J Biol Macromol 108: 916-926.

423. Vishchuk OS, Ermakova SP, Zvyagintseva TN (2011) Sulfated polysaccharides from brown seaweeds Saccharina japonica and Undaria pinnatifida: isolation, structural characteristics, and antitumor activity. Carbohydr 346(17): 2769-2776.

424. Vaseghi G, Sharifi M, Dana N, Ghasemi A, Yegdaneh A. Cytotoxicity of Sargassum angustifolium Partitions against Breast and Cervical Cancer Cell Lines. Adv Biomed Res 7: 43.

425. Kim EK, Tang Y, Kim YS, Hwang JW, Choi EJ, et al. (2015) First evidence that Ecklonia cava-derived dieckol attenuates MCF-7 human breast carcinoma cell migration. Mar Drugs 13(4): 1785-1797.

426. Araghi M, Soerjomataram I, Jenkins M, Brierley J, Morris E, et al. (2019) Global trends in colorectal cancer mortality: projections to the year 2035. Int J Cancer 144 (12): 2992-3000.

427. Recio-Boiles A, Waheed A, Cagir B (2019) Cancer, Colon. Stat Pearls Treasure Island. 


\section{Advances in Pharmacology and Clinical Trials}

428. Virk GS, Jafri M, Ashley C (2019) Colonoscopy and colorectal cancer rates among octogenarians and nonagenarians: nationwide study of US veterans. Clin Interv Aging 14: 609-614.

429. PDQ (2002) Colorectal Cancer Prevention (PDQ®). Health Professional Version, PDQ Screening and Prevention Editorial Board.

430. Chen W, Zheng R, Baade PD, Zhang S, Zeng H, et al. (2016) Cancer statistics in China, 2015. CA Cancer J Clin 66(2): 115-132.

431. Araghi M, Soerjomataram I, Bardot A, Ferlay J, Cabasag CJ, et al. (2019) Changes in colorectal cancer incidence in seven high-income countries: a population-based study. Lancet Gastroenterol Hepatol 4(7): 511-518.

432. Wray AJD, Minaker LM (2019) Is cancer prevention influenced by the built environment? A multidisciplinary scoping review. Cancer 125(19): 3299-3311.

433. Poirier AE, Ruan Y, Walter SD, Franco EL, Villeneuve PJ, et al. (2019) The future burden of cancer in Canada: Long-term cancer incidence projections 2013-2042. Cancer Epidemiol 59: 199-207.

434. Poirier AE, Ruan Y, Hebert LA, Grevers X, Walter SD, et al. (2019) Estimates of the current and future burden of cancer attributable to low fruit and vegetable consumption in Canada. Prev Med 122: 20 30.

435. Feletto E, Yu XQ, Lew JB, St John DJB, Jenkins MA, et al. (2019) Trends in Colon and Rectal Cancer Incidence in Australia from 1982 to 2014: Analysis of Data on Over 375,000 Cases. Cancer Epidemiol Biomarkers Prev 28(1): 83-90.

436. Jenkins MA, Ait Ouakrim D, Boussioutas A, Hopper JL, Ee HC, et al. (2018) Revised Australian national guidelines for colorectal cancer screening: family history. Med J Aust 209(10): 455-460.

437. Glover M, Mansoor E, Panhwar M, Parasa S, Cooper GS (2019) Epidemiology of Colorectal Cancer in Average Risk Adults 20-39 Years of Age: A Population-Based National Study. Dig Dis Sci.

438. Siegel RL, Medhanie GA, Fedewa SA, Jemal A (2019) State variation in early-onset colorectal cancer in the United States, 1995-2015. J Natl Cancer Inst, pp: djz098.
439. Mannucci A, Zuppardo RA, Rosati R, Leo MD, Perea J, et al. (2019) Colorectal cancer screening from 45 years of age: Thesis, antithesis and synthesis. World J Gastroenterol 25(21): 2565-2580.

440. Erdrich J, Zhang X, Giovannucci E, Willett W (2015) Proportion of colon cancer attributable to lifestyle in a cohort of US women. Cancer Causes Control 26(9): 1271-1279.

441. Aleksandrova K, Pischon T, Jenab M, Bueno-deMesquita HB, Fedirko V, et al. (2014) Combined impact of healthy lifestyle factors on colorectal cancer: a large European cohort study 12: 168.

442. Jeon J, Du M, Schoen RE, Hoffmeister M, Newcomb PA, et al. (2018) Determining Risk of Colorectal Cancer and Starting Age of Screening Based on Lifestyle, Environmental, and Genetic Factors. Gastroenterology 154(8): 2152-2164.

443. Oruç Z, Kaplan MA (2019) Effect of exercise on colorectal cancer prevention and treatment. World J Gastrointest Oncol 11(5): 348-366.

444. Bradbury KE, Murphy N, Key TJ (2019) Diet and colorectal cancer in UK Biobank: a prospective study. Int J Epidemiol, pp: dyz064.

445. Fedirko V, Tramacere I, Bagnardi V, Rota M, Scotti L, et al. (2011) Alcohol drinking and colorectal cancer risk: an overall and dose-response meta-analysis of published studies. Ann Oncol 22(9):1958-1972.

446. Vieira AR, Abar L, Chan DSM, Vingeliene S, Polemiti E, et al. (2017) Foods and beverages and colorectal cancer risk: a systematic review and meta-analysis of cohort studies, an update of the evidence of the WCRF-AICR Continuous Update Project. Ann Oncol 28(8): 1788-1802.

447. Pericleous M, Mandair D, Caplin ME (2013) Diet and supplements and their impact on colorectal cancer. J Gastrointest Oncol 4(4): 409-423.

448. Chen Z, Wang PP, Woodrow J, Zhu Y, Roebothan B, et al. (2015) Dietary patterns and colorectal cancer: results from a Canadian population-based study. Nutr J 14: 8.

449. National Cancer Institute (2019) Financial Burden of Cancer Care.

450. American Cancer Society (2017) Colorectal Cancer Facts \& Figures 2017-2019. 


\section{Advances in Pharmacology and Clinical Trials}

451. Gellad ZF, Provenzale D (2010) Colorectal cancer: national and international perspective on the burden of disease and public health impact. Gastroenterology 138(6): 2177-2190.

452. Colorectal cancer statistics (2018) World Cancer Research Fund International.

453. Rodriguez-Bigas MA, Lin EH, Crane CH (2003) Stage IV Colorectal Cancer. In: Kufe DW, Pollock RE, Weichselbaum RR, et al., editors. Holland-Frei Cancer Medicine. $6^{\text {th }}$ (Edn.), Hamilton.

454. Lee SD, Choe JW, Lee BJ, Kang MH, Joo MK, et al. (2015) Butein effects in colitis and interleukin6/signal transducer and activator of transcription 3 expression. World J Gastroenterol 21(2): 465-474.

455. Yang Y, Zhang J, Weiss NS, Guo L, Zhang L, et al. (2019) The consumption of chili peppers and the risk of colorectal cancer: a matched case-control study. World J Surg Oncol 17(1): 71.

456. Bar-Shalom R, Bergman M, Grossman S, Azzam N, Sharvit L, et al. (2019) Inula Viscosa Extract Inhibits Growth of Colorectal Cancer Cells in vitro and in vivo Through Induction of Apoptosis. Front Oncol 9: 227.

457. Tong J, Shen Y, Zhang Z, Hu Y, Zhang X, et al. (2019) Apigenin inhibits epithelial-mesenchymal transition of human colon cancer cells through NF- $\mathrm{KB} /$ Snail signaling pathway. Biosci Rep 39(5).

458. Aggarwal B, Prasad S, Sung B, Krishnan S, Guha S (2013) Prevention and Treatment of Colorectal Cancer by Natural Agents From Mother Nature. Curr Colorectal Cancer Rep 9(1): 37-56.

459. Kumar S, Agnihotri N (2019) Piperlongumine, a piper alkaloid targets Ras/PI3K/Akt/mTOR signaling axis to inhibit tumor cell growth and proliferation in DMH/DSS induced experimental colon cancer. Biomed Pharmacother 109: 1462-1477.

460. Xu J, Long Y, Ni L, Yuan X, Yu N, et al. (2019) Anticancer effect of berberine based on experimental animal models of various cancers: a systematic review and meta-analysis. BMC Cancer 19(1): 589.

461. Dai W, Mu L, Cui Y, Li Y, Chen P, et al. (2019) Berberine Promotes Apoptosis of Colorectal Cancer via Regulation of the Long Non-Coding RNA (lncRNA) Cancer Susceptibility Candidate 2 (CASC2)/AUBinding Factor 1 (AUF1)/B-Cell CLL/Lymphoma 2 (Bcl-2) Axis. Med Sci Monit 25: 730-738.
462. Gonzalez-Sarrias A, Nunez-Sanchez MA, TomeCarneiro J, Tomas-Barberan FA, Garcia-Conesa MT, et al. (2016) Comprehensive characterization of the effects of ellagic acid and urolithins on colorectal cancer and key-associated molecular hallmarks: MicroRNA cell specific induction of CDKN1A (p21) as a common mechanism involved. Mol Nutr Food Res 60(4): 701-716.

463. Nunez-Sanchez MA, Davalos A, Gonzalez-Sarrias A, Casas-Agustench P, Visioli F, et al. (2015) MicroRNAs expression in normal and malignant colon tissues as biomarkers of colorectal cancer and in response to pomegranate extracts consumption: Critical issues to discern between modulatory effects and potential artefacts. Mol Nutr Food Res 59(10): 1973-1986.

464. Nunez-Sanchez MA, Gonzalez-Sarrias A, GarciaVillalba R, Monedero-Saiz T, Garcia-Talavera NV, et al. (2017) Gene expression changes in colon tissues from colorectal cancer patients following the intake of an ellagitannin-containing pomegranate extract: a randomized clinical trial. J Nutr Biochem 42: 126-133.

465. Baxter BA, Oppel RC, Ryan EP (2018) Navy Beans Impact the Stool Metabolome and Metabolic Pathways for Colon Health in Cancer Survivors. Nutrients 11(1): 28.

466. Bogachek MV, Park JM, De Andrade JP, Lorenzen AW, Kulak MV, et al. (2016) Inhibiting the SUMO Pathway Represses the Cancer Stem Cell Population in Breast and Colorectal Carcinomas. Stem Cell Reports 7(6): 1140-1151.

467. Gong X, Chen Z, Han Q, Chen C, Jing L, et al. (2018) Sanguinarine triggers intrinsic apoptosis to suppress colorectal cancer growth through disassociation between STRAP and MELK. BMC Cancer 18(1): 578.

468. Zeng A, Hua H, Liu L, Zhao J (2019) Corrigendum to 'Betulinic acid induces apoptosis and inhibits metastasis of human colorectal cancer cells in vitro and in vivo' [Bioorg. Med. Chem. 27 (2019) 25462552]. Bioorg Med Chem 27(19).

469. Dutta D, Paul B, Mukherjee B, Mondal L, Sen S, et al. (2019) Nanoencapsulated betulinic acid analogue distinctively improves colorectal carcinoma in vitro and in vivo. Sci Rep 9(1): 11506.

470. Toden S, Okugawa Y, Buhrmann C, Nattamai D, Anguiano E, et al. (2015) Novel Evidence for Curcumin and Boswellic Acid-Induced 


\section{Advances in Pharmacology and Clinical Trials}

Chemoprevention through Regulation of miR-34a and miR-27a in Colorectal Cancer. Cancer Prev Res (Phila) 8(5): 431-443.

471. Leu JD, Wang BS, Chiu SJ, Chang CY, Chen CC, et al. (2016) Combining fisetin and ionizing radiation suppresses the growth of mammalian colorectal cancers in xenograft tumor models. Oncol 12(6): 4975-4982.

472. Huang YT, Lin CI, Chien PH, Tang TT, Lin J, et al. (2014) The depletion of securin enhances buteininduced apoptosis and tumor inhibition in human colorectal cancer. Chem Biol Interact 220: 41-50.

473. Yit CC, Das NP (1994) Cytotoxic effect of butein on human colon adenocarcinoma cell proliferation. Cancer Lett 82(1): 65-72.

474. Zhang L, Yang X, Li X, Li C, Zhao L, et al. (2015) Butein sensitizes HeLa cells to cisplatin through the AKT and ERK/p38 MAPK pathways by targeting Fox03a. Int J Mol Med 36(4): 957-966.

475. Jin J, Lin G, Huang H, Xu D, Yu H, et al. (2014) Capsaicin mediates cell cycle arrest and apoptosis in human colon cancer cells via stabilizing and activating p53. Int J Biol Sci 10(3): 285-295.

476. Lee SH, Clark R (2016) Anti-Tumorigenic Effects of Capsaicin in Colon Cancer. J Food Chem Nanotechnol 2(4): 162-167

477.

478. Ozmen N, Kaya-Sezginer E, Bakar-Ates F (2018) The Cellular Uptake and Apoptotic Efficiency of Colchicine is correlated with Downregulation of MMP-9 mRNA Expression in SW480 Colon Cancer Cells. Anticancer Agents Med Chem 18(13): 1927-1933.

479. Huang Z, Xu Y, Peng W (2015) Colchicine induces apoptosis in HT-29 human colon cancer cells via the AKT and c-Jun $\mathrm{N}$-terminal kinase signaling pathways. Mol Med Rep 12(4): 5939-5944.

480. Zhang T, Chen W, Jiang X, Liu L, Wei K, et al. (2019) Anticancer effects and underlying mechanism of Colchicine on human gastric cancer cell lines in vitro and in vivo. Biosci Rep 39(1).

481. Saud SM, Li W, Morris NL, Matter MS, Colburn NH, et al. (2014) Resveratrol prevents tumorigenesis in mouse model of Kras activated sporadic colorectal cancer by suppressing oncogenic Kras expression. Carcinogenesis 35(12): 2778-2786.

482. Saud SM, Li W, Morris NL, Matter MS, Colburn NH, et al. (2014) Resveratrol prevents tumorigenesis in mouse model of Kras activated sporadic colorectal cancer by suppressing oncogenic Kras expression. Carcinogenesis 35(12): 2778-2786.

483. Altamemi I, Murphy EA, Catroppo JF, Zumbrun EE, Zhang J, et al. (2014) Role of microRNAs in resveratrol-mediated mitigation of colitis-associated tumorigenesis in Apc(Min/+) mice. J Pharmacol Exp Ther 350(1): 99-109.

484. Chung SS, Wu Y, Okobi Q, Adekoya D, Atefi M, et al. (2017) Proinflammatory Cytokines IL-6 and TNF- $\alpha$ Increased Telomerase Activity through NF$\kappa B / S T A T 1 / S T A T 3$ Activation, and Withaferin A Inhibited the Signaling in Colorectal Cancer Cells. Mediators Inflamm 2017: 5958429.

485. Reddivari L, Charepalli V, Radhakrishnan S, Vadde R, Elias RJ, et al. (2016) Grape compounds suppress colon cancer stem cells in vitro and in a rodent model of colon carcinogenesis. BMC Complement Altern Med 16: 278.

486. Kumazaki M, Noguchi S, Yasui Y, Iwasaki J, Shinohara $\mathrm{H}$, et al. (2013) Anti-cancer effects of naturally occurring compounds through modulation of signal transduction and miRNA expression in human colon cancer cells. J Nutr Biochem 24(11): 1849-1858.

487. Raja SB, Rajendiran V, Kasinathan NK, P A, Venkatabalasubramanian S, et al. (2017) Differential cytotoxic activity of Quercetin on colonic cancer cells depends on ROS generation through COX-2 expression. Food Chem Toxicol 106(Pt A): 92-106.

488. Yang L, Liu Y, Wang M, Qian Y, Dong X, et al. (2016) Quercetin-induced apoptosis of HT-29 colon cancer cells via inhibition of the Akt-CSN6-Myc signaling axis. Mol Med Rep 14(5): 4559-4566.

489. Kim HJ, Kim SK, Kim BS, Lee SH, Park YS, et al. (2010) Apoptotic effect of quercetin on HT-29 colon cancer cells via the AMPK signaling pathway. J Agric Food Chem 58(15): 8643-2650.

490. Refolo MG, D'Alessandro R, Malerba N, Laezza C, Bifulco M, et al. (2015) Anti Proliferative and Pro Apoptotic Effects of Flavonoid Quercetin Are Mediated by CB1 Receptor in Human Colon Cancer Cell Lines. J Cell Physiol 230(12): 2973-2980. 


\section{Advances in Pharmacology and Clinical Trials}

491. Zhang XA, Zhang S, Yin Q, Zhang J. Quercetin induces human colon cancer cells apoptosis by inhibiting the nuclear factor-kappa B Pathway. Pharmacogn Mag 11(42): 404-409.

492. James S, Aparna JS, Paul AM, Lankadasari MB, Mohammed S, et al. (2017) Cardamonin inhibits colonic neoplasia through modulation of MicroRNA expression. Sci Rep 7(1): 13945.

493. Park S, Gwak J, Han SJ, Oh S (2013) Cardamonin suppresses the proliferation of colon cancer cells by promoting $\beta$-catenin degradation. Biol Pharm Bull 36(6):1040-1044.

494. Lu S, Lin C, Cheng X, Hua H, Xiang T, et al. (2018) Cardamonin reduces chemotherapy resistance of colon cancer cells via the TSP50/NF- $\mathrm{KB}$ pathway in vitro. Oncol Lett 15(6): 9641-9646.

495. Jiang Z, Cao Q, Dai G, Wang J, Liu C, et al. (2019) Celastrol inhibits colorectal cancer through TGF$\beta 1 /$ Smad signaling. Onco Targets Ther 12: 509-518.

496. Gao Y, Zhou S, Pang L, Yang J, Li HJ, et al. (2019) Celastrol suppresses nitric oxide synthases and the angiogenesis pathway in colorectal cancer. Free Radic Res 53(3): 324-334.

497. Moreira H, Szyjka A, Gąsiorowski K (2018) Chemopreventive activity of celastrol in drugresistant human colon carcinoma cell cultures. Oncotarget 9(30): 21211-21223.

498. Bufu T, Di X, Yilin Z, Gege L, Xi C, Ling W (2018) Celastrol inhibits colorectal cancer cell proliferation and migration through suppression of MMP3 and MMP7 by the PI3K/AKT signaling pathway. Anticancer Drugs 29(6): 530-538.

499. Xiao-Pei H, Ji-Kuai C, Xue W, Dong YF, Yan L, et al. (2018) Systematic identification of Celastrol-binding proteins reveals that Shoc2 is inhibited by Celastrol. Biosci Rep 38(6): BSR20181233.

500. Chen L, Jiang K, Chen H, Tang Y, Zhou X, et al. (2018) Deguelin induces apoptosis in colorectal cancer cells by activating the p38 MAPK pathway. Cancer Manag Res 11: 95-105.

501. Murillo G, Salti GI, Kosmeder JW, Pezzuto JM, Mehta RG (2002) Deguelin inhibits the growth of colon cancer cells through the induction of apoptosis and cell cycle arrest. Eur J Cancer 38(18): 2446-2454.
502. Lokhande KB, Nagar S, Swamy KV (2019) Molecular interaction studies of Deguelin and its derivatives with Cyclin D1 and Cyclin E in cancer cell signaling pathway: The computational approach. Sci Rep 9(1): 1778.

503. Kang W, Zheng X, Wang P, Guo S (2018) Deguelin exerts anticancer activity of human gastric cancer MGC-803 and MKN-45 cells in vitro. Int J Mol Med 41(6): 3157-3166.

504. Raju J, Bird RP (2007) Diosgenin, a naturally occurring steroid [corrected] saponin suppresses 3hydroxy-3-methylglutaryl CoA reductase expression and induces apoptosis in HCT-116 human colon carcinoma cells. Cancer Lett 255(2): 194-204.

505. Lepage C, Léger DY, Bertrand J, Martin F, Beneytout JL, et al. (2011) Diosgenin induces death receptor-5 through activation of p38 pathway and promotes TRAIL-induced apoptosis in colon cancer cells. Cancer Lett 301(2): 193-202.

506. Jesus M, Martins AP, Gallardo E, Silvestre S (2016) Diosgenin: Recent Highlights on Pharmacology and Analytical Methodology. J Anal Methods Chem 2016: 4156293.

507. Sethi G, Shanmugam MK, Warrier S, Merarchi M, Arfuso F, et al. (2018) Pro-Apoptotic and Anti-Cancer Properties of Diosgenin: A Comprehensive and Critical Review. Nutrients 10(5): E645.

508. Dai G, Ding K, Cao Q, Xu T, He F, et al. (2019) Emodin suppresses growth and invasion of colorectal cancer cells by inhibiting VEGFR2. Eur J Pharmacol 859: 172525.

509. Gu J, Cui CF, Yang L, Wang L, Jiang XH (2019) Emodin Inhibits Colon Cancer Cell Invasion and Migration by Suppressing Epithelial-Mesenchymal Transition via the Wnt/ $\beta$-Catenin Pathway. Oncol Res 27(2): 193202.

510. Saunders IT, Mir H, Kapur N, Singh S (2019) Emodin inhibits colon cancer by altering BCL-2 family proteins and cell survival pathways. Cancer Cell Int 19: 98.

511. Wang Y, Luo Q, He X, Wei H, Wang T, et al. (2018) Emodin Induces Apoptosis of Colon Cancer Cells via Induction of Autophagy in a ROS-Dependent Manner. Oncol Res 26(6): 889-899. 


\section{Advances in Pharmacology and Clinical Trials}

512. Wu T, Wang C, Wang W, Hui Y, Zhang R, et al. (2018) Embelin impairs the accumulation and activation of MDSCs in colitis-associated tumorigenesis. Oncoimmunology 7(11): e1498437.

513. Dai Y, Jiao H, Teng G, Wang W, Zhang R, et al. (2014) Embelin reduces colitis-associated tumorigenesis through limiting IL-6/STAT3 signaling. Mol Cancer Ther 13(5): 1206-1216.

514. Wu T, Dai Y, Wang W, Teng G, Jiao H, et al. (2016) Macrophage targeting contributes to the inhibitory effects of embelin on colitis-associated cancer. Oncotarget 7(15): 19548-1958.

515. Cheng C, Dong W (2018) Aloe-Emodin Induces Endoplasmic Reticulum Stress-Dependent Apoptosis in Colorectal Cancer Cells. Med Sci Monit 24: 63316339.

516. Bedi D, Henderson HJ, Manne U, Samuel T (2019) Camptothecin Induces PD-L1 and Immunomodulatory Cytokines in Colon Cancer Cells. Medicines (Basel) 6(2): E51.

517. Yang N, Zhao Y, Wang Z, Liu Y, Zhang Y (2017) Scutellarin suppresses growth and causes apoptosis of human colorectal cancer cells by regulating the p53 pathway. Mol Med Rep 15(2): 929-935.

518. Kang KA, Piao MJ, Ryu YS, Hyun YJ, Park JE, et al. (2017) Luteolin induces apoptotic cell death via antioxidant activity in human colon cancer cells. Int J Oncol 51(4): 1169-1178.

519. Di Francesco A, Falconi A, Di Germanio C, Micioni Di Bonaventura MV, et al. (2015) Extravirgin olive oil up-regulates $\mathrm{CB}_{1}$ tumor suppressor gene in human colon cancer cells and in rat colon via epigenetic mechanisms. J Nutr Biochem 26(3): 250-258.

520. Huang GM, Sun Y, Ge X, Wan X, Li CB (2015) Gambogic acid induces apoptosis and inhibits colorectal tumor growth via mitochondrial pathways. World J Gastroenterol 21(20): 6194-6205.

521. Tsoukas MA, Ko BJ, Witte TR, Dincer F, Hardman WE, et al. (2015) Dietary walnut suppression of colorectal cancer in mice: Mediation by miRNA patterns and fatty acid incorporation. J Nutr Biochem 26(7): 77683.

522. Kim J, Lee J, Oh JH, Chang HJ, Sohn DK, et al. (2019) Associations among dietary seaweed intake, c-MYC rs6983267 polymorphism, and risk of colorectal cancer in a Korean population: a case-control study. Eur J Nutr.

523. Zhao Y, Zheng Y, Wang J, Ma S, Yu Y, et al. (2018) Fucoidan Extracted from Undaria pinnatifida: Source for Nutraceuticals/Functional Foods. Mar Drugs 16(9): E321.

524. Tsai HL, Tai CJ, Huang CW, Chang FR, Wang JY (2017) Efficacy of Low-Molecular-Weight Fucoidan as a Supplemental Therapy in Metastatic Colorectal Cancer Patients: A Double-Blind Randomized Controlled Trial. Mar Drugs 15(4): E122.

525. Wang SK, Li Y, White WL, Lu J (2014) Extracts from New Zealand Undaria pinnatifida Containing Fucoxanthin as Potential Functional Biomaterials against Cancer in Vitro. J Funct Biomater 5(2): 29-42.

526. Han YS, Lee JH, Lee SH (2015) Fucoidan inhibits the migration and proliferation of HT-29 human colon cancer cells via the phosphoinositide-3 kinase/Akt/mechanistic target of rapamycin pathways. Mol Med Rep 12(3): 3446-3452.

527. Han YS, Lee JH, Lee SH (2015) Antitumor Effects of Fucoidan on Human Colon Cancer Cells via Activation of Akt Signaling. Biomol Ther (Seoul) 23(3): 225-232.

528. Chen LM, Liu PY, Chen YA, Tseng HY, Shen PC, (2017) Oligo-Fucoidan prevents IL-6 and CCL2 production and cooperates with p53 to suppress ATM signaling and tumor progression. Sci Rep 7(1): 11864.

529. Kim SK, Karagozlu MZ (2011) Marine algae: Natural Product Source for the gastrointestinal Cancer Treatment. In: Marine Medicinal Foods: Implications and Applications, Macro and Microalgae. Advances in Food and Nutrition Research 64(7).

530. Bakunina I, Chadova O, Malyarenko O, Ermakova S (2018) The Effect of Fucoidan from the Brown Alga Fucus evanescence on the Activity of $\alpha-\mathrm{N}$ Acetylgalactosaminidase of Human Colon Carcinoma Cells. Mar Drugs 16(5): E155.

531. Kim IH, Kwon MJ, Nam TJ (2017) Differences in cell death and cell cycle following fucoidan treatment in high-density HT-29 colon cancer cells. Mol Med Rep 15(6): 4116-4122.

532. Tsai CF, Yeh WL, Chen JH, Lin C, Huang SS, et al. (2014) Osthole suppresses the migratory ability of human glioblastoma multiforme cells via inhibition of focal adhesion kinase-mediated matrix 


\section{Advances in Pharmacology and Clinical Trials}

metalloproteinase-13 expression. Int J Mol Sci 15(3): 3889-3903.

533. Kim HY, Kim YM, Hong S (2019) Astaxanthin suppresses the metastasis of colon cancer by inhibiting the MYC-mediated downregulation of microRNA-29a-3p and microRNA-200a. Sci Rep 9(1): 9457.

534. Nagendraprabhu P, Sudhandiran G (2011) Astaxanthin inhibits tumor invasion by decreasing extracellular matrix production and induces apoptosis in experimental rat colon carcinogenesis by modulating the expressions of ERK-2, NFkB and COX2. Invest New Drugs 29(2): 207-224.

535. Hormozi M, Ghoreishi S, Baharvand P (2019) Astaxanthin induces apoptosis and increases activity of antioxidant enzymes in LS-180 cells. Artif Cells Nanomed Biotechnol 47(1): 891-895.

536. Yasui Y, Hosokawa M, Mikami N, Miyashita K, Tanaka T (2011) Dietary astaxanthin inhibits colitis and colitis-associated colon carcinogenesis in mice via modulation of the inflammatory cytokines. Chem Biol Interact 193(1): 79-87.

537. Liu X, Song M, Gao Z, Cai X, Dixon W, et al. (2016) Stereoisomers of Astaxanthin Inhibit Human Colon Cancer Cell Growth by Inducing G2/M Cell Cycle Arrest and Apoptosis. J Agric Food Chem 64(41): 7750-7759.

538. Wayakanon K, Rueangyotchanthana K, Wayakanon P, Suwannachart C (2018) The inhibition of Caco-2 proliferation by astaxanthin from Xanthophyllomyces dendrorhous. J Med Microbiol 67(4): 507-513.

539. Tanaka T, Kawamori T, Ohnishi M, Makita H, Mori H, et al. (1995) Suppression of azoxymethane-induced rat colon carcinogenesis by dietary administration of naturally occurring xanthophylls astaxanthin and canthaxanthin during the postinitiation phase. Carcinogenesis 16(12): 2957-2963.

540. Terasaki M, Iida T, Kikuchi F, Tamura K, Endo T, et al. (2019) Fucoxanthin potentiates anoikis in colon mucosa and prevents carcinogenesis in AOM/DSS model mice. J Nutr Biochem 64: 198-205.

541. Terasaki M, Masaka S, Fukada C, Houzaki M, Endo T, et al. (2019) Salivary Glycine Is a Significant Predictor for the Attenuation of Polyp and Tumor Microenvironment Formation by Fucoxanthin in AOM/DSS Mice. In Vivo 33(2): 365-374.
542. Terasaki M, Matsumoto N, Hashimoto R, Endo T, Maeda H, et al. (2019)Fucoxanthin administration delays occurrence of tumors in xenograft mice by colonospheres, with an anti-tumor predictor of glycine. J Clin Biochem Nutr 64(1): 52-58.

543. Das SK, Hashimoto T, Shimizu K, Yoshida T, Sakai T, et al. (2005) Fucoxanthin induces cell cycle arrest at G0/G1 phase in human colon carcinoma cells through up-regulation of p21WAF1/Cip1. Biochim Biophys Acta 1726(3): 328-335.

544. Hosokawa M, Kudo M, Maeda H, Kohno H, Tanaka T, et al. (2004) Fucoxanthin induces apoptosis and enhances the antiproliferative effect of the PPARgamma ligand, troglitazone, on colon cancer cells. Biochim Biophys 1675(1-3): 113-119.

545. Kim JM, Araki S, Kim DJ, Park CB, Takasuka N, et al. (1998) hemopreventive effects of carotenoids and curcumins on mouse colon carcinogenesis after 1,2dimethylhydrazine initiation. Carcinogenesis 19(1): 81-85.

546. Konishi I, Hosokawa M, Sashima T, Kobayashi H, Miyashita K (2006) Halocynthiaxanthin and fucoxanthinol isolated from Halocynthia roretzi induce apoptosis in human leukemia, breast and colon cancer cells. Comp Biochem Physiol C Toxicol Pharmacol 142(1-2): 53-59.

547. Kim J, Lee J, Oh JH, Chang HJ, Sohn DK, et al. (2019) Dietary Lutein Plus Zeaxanthin Intake and DICER1 rs3742330 A > G Polymorphism Relative to Colorectal Cancer Risk. Sci Rep 9(1): 3406.

548. Reynoso Camacho R, González Jasso E, Ferriz Martínez R, Villalón Corona B, Loarca Piña GF, et al. (2011) Dietary supplementation of lutein reduces colon carcinogenesis in DMH-treated rats by modulating K-ras, $\mathrm{PKB}$, and $\beta$-catenin proteins. Nutr Cancer 63(1): 39-45.

549. Grudzinski W, Piet M, Luchowski R, Reszczynska E, Welc R, et al. (2017) Different molecular organization of two carotenoids, lutein and zeaxanthin, in human colon epithelial cells and colon adenocarcinoma cells. Spectrochim Acta A Mol Biomol Spectrosc 188: 57-63.

550. Kohler LN, Harris RB, Oren E, Roe DJ, Lance P, et al. (2018) Adherence to Nutrition and Physical Activity Cancer Prevention Guidelines and Development of Colorectal Adenoma 10(8): E1098. 


\section{Advances in Pharmacology and Clinical Trials}

551. Wang ZJ, Ohnaka K, Morita M, Toyomura K, Kono S, et al. (2013) Dietary polyphenols and colorectal cancer risk: the Fukuoka colorectal cancer study. World J Gastroenterol 19(17): 2683-2690.

552. Alam MN, Almoyad M, Huq F (2018) Polyphenols in Colorectal Cancer: Current State of Knowledge including Clinical Trials and Molecular Mechanism of Action. Biomed Res Int, pp: 4154185.

553. Murphy N, Achaintre D, Zamora-Ros R, Jenab M, Boutron-Ruault MC, et al. (2018) A prospective evaluation of plasma polyphenol levels and colon cancer risk. Int J Cancer.

554. Mileo AM, Nisticò P, Miccadei S (2019) Polyphenols: Immunomodulatory and Therapeutic Implication in Colorectal Cancer. Front Immunol 10: 729.

555. Zamora-Ros R, Cayssials V, Jenab M, Rothwell JA, Fedirko V, (2018) Dietary intake of total polyphenol and polyphenol classes and the risk of colorectal cancer in the European Prospective Investigation into Cancer and Nutrition (EPIC) cohort. Eur J Epidemiol 33(11): 1063-1075.

556. Ishida $Y$, Gao R, Shah N, Bhargava $P$, Furune $T$, et al. (2018) Anticancer Activity in Honeybee Propolis: Functional Insights to the Role of Caffeic Acid Phenethyl Ester and Its Complex With $\gamma$-Cyclodextrin. Integr Cancer Ther 17(3): 867-873.

557. Stähli A, Maheen CU, Strauss FJ, Eick S, Sculean A, et al. (2019) Caffeic acid phenethyl ester protects against oxidative stress and dampens inflammation via heme oxygenase 1. Int J Oral Sci 11(1): 6.

558. Murtaza G, Karim S, Akram MR, Khan SA, Azhar S, et al. (2014) Caffeic acid phenethyl ester and therapeutic potentials. Biomed Res Int 2014: 145342.

559. Robertson J, Raizer J, Hodges JS, Gradishar W, Allen JA (2018) Risk factors for the development of paclitaxel-induced neuropathy in breast cancer patients. J Peripher Nerv Syst 23(2): 129-133.

560. Zang X, Lee JB, Deshpande K, Garbuzenko OB, Minko $\mathrm{T}$, et al. (2019) Prevention of paclitaxel-induced neuropathy by formulation approach. J Control Release 303: 109-116.

561. Vahdat L, Papadopoulos K, Lange D, Leuin S, Kaufman E, et al. (2001) Reduction of paclitaxelinduced peripheral neuropathy with glutamine. Clin Cancer Res 7(5): 1192-1197.
562. Kaur S, Muthuraman A (2019) Ameliorative effect of gallic acid in paclitaxel-induced neuropathic pain in mice. Toxicol Rep 6: 505-513.

563. Chou CK, Huang HW, Yang CF, Dahms HU, Liang SS, et al. (2019) Reduced camptothecin sensitivity of estrogen receptor-positive human breast cancer cells following exposure to di(2-ethylhexyl)phthalate (DEHP) is associated with DNA methylation changes. Environ Toxicol 34(4): 401-414.

564. Xu H, Krystal GW (2010) Actinomycin D decreases Mcl-1 expression and acts synergistically with ABT737 against small cell lung cancer cell lines. Clin Cancer Res 16(17): 4392-4400.

565. Merkel O, Wacht N, Sifft E, Melchardt T, Hamacher F, et al. (2012) Actinomycin D induces p53-independent cell death and prolongs survival in high-risk chronic lymphocytic leukemia. Leukemia 26(12): 2508-2516.

566. Ishii M, Iwai M, Harada Y, Kishida T, Asada H, et al. (2007) Soluble TRAIL gene and actinomycin D synergistically suppressed multiple metastasis of TRAIL-resistant colon cancer in the liver. Cancer Lett 245(1-2): 134-143.

567. Pinto A, Pocard M (2019) Hyperthermic intraperitoneal chemotherapy with cisplatin and mitomycin $\mathrm{C}$ for colorectal cancer peritoneal metastases: A systematic review of the literature. Pleura Peritoneum 4(2): 20190006.

568. Symer MM, Yeo HL (2018) Recent advances in the management of anal cancer. F1000Res. 7: F1000.

569. Tan LT, Chan KG, Pusparajah P, Yin WF, Khan TM, et al. (2019) Mangrove derived Streptomyces sp. MUM265 as a potential source of antioxidant and anticolon-cancer agents. BMC Microbiol 19(1): 38.

570. Sakamoto K, Ito S, Hashimoto N, Hasegawa Y (2017) Pirfenidone as salvage treatment for refractory bleomycin-induced lung injury: a case report of seminoma. BMC Cancer 17(1): 526.

571. Yu H, Zhang Z, Huang H, Wang Y, Lin B, et al. (2019) Inhibition of bleomycin-induced pulmonary fibrosis in mice by the novel peptide EZY-1 purified from Eucheuma. Food Funct 10(6): 3198-3208.

572. Lan C, Wolf SL, Tsang WW (2013) Tai chi exercise in medicine and health promotion. Evid Based Complement Alternat Med 2013: 298768. 


\section{Advances in Pharmacology and Clinical Trials}

573. Streckmann F, Balke M, Lehmann HC, Rustler V, Koliamitra C, et al. (2018) The preventive effect of sensorimotor- and vibration exercises on the onset of Oxaliplatin- or vinca-alkaloid induced peripheral neuropathies - STOP. BMC Cancer 18(1): 62.

574. Elkins G, White J, Patel P, Marcus J, Perfect MM, et al. (2006) Hypnosis to manage anxiety and pain associated with colonoscopy for colorectal cancer screening: Case studies and possible benefits. Int J Clin Exp Hypn 54(4): 416-431.

575. Cossu G, Saba L, Minerba L, Mascalchi M (2018) Colorectal Cancer Screening: The Role of Psychological, Social and Background Factors in Decision-making Process. Clin Pract Epidemiol Ment Health 14: 63-69.

576. Montgomery GH, Schnur JB, Kravits K (2013) Hypnosis for cancer care: over 200 years young. CA Cancer J Clin 63(1): 31-44.

577. Miller SJ, Schnur JB, Montgomery GH, Jandorf L (2011) African-Americans' and Latinos' Perceptions of Using Hypnosis to Alleviate Distress before a Colonoscopy. Contemp Hypn Integr Ther 28(3): 196203.

578. Umezawa S, Higurashi T, Uchiyama S, Sakai E, Ohkubo H, et al. (2015) Visual distraction alone for the improvement of colonoscopy-related pain and satisfaction. World J Gastroenterol 21(15): 47074714 .

579. Lee DW, Chan AC, Wong SK, Fung TM, Li AC, et al. (2004) Can visual distraction decrease the dose of patient-controlled sedation required during colonoscopy? A prospective randomized controlled trial. Endoscopy 36(3): 197-201.

580. Xiaolian J, Xiaolin L, Lan ZH (2015) Effects of visual and audiovisual distraction on pain and anxiety among patients undergoing colonoscopy. Gastroenterol Nurs 38(1): 55-61.

581. Leung FW, Surinder KM, Joseph WL, Rodelei MS, Jackson G (2008) Methods of reducing discomfort during colonoscopy. Dig Dis Sci 53(6): 1462-1467.

582. De Silva AP, Niriella MA, Nandamuni Y, Nanayakkara SD, Perera KR, et al. (2016) Effect of audio and visual distraction on patients undergoing colonoscopy: a randomized controlled study. Endosc Int Open 4(11): E1211-E1214.
583. Sun H, Huang H, Ji S, Chen X, Xu Y, et al. (2019) The Efficacy of Cognitive Behavioral Therapy to Treat Depression and Anxiety and Improve Quality of Life Among Early-Stage Breast Cancer Patients. Integr Cancer Ther 18: 1534735419829573.

584. Eichler C, Pia M, Sibylle M, Sauerwald A, Friedrich W, et al. (2015) Cognitive behavioral therapy in breast cancer patients--a feasibility study of an 8 week intervention for tumor associated fatigue treatment. Asian Pac J Cancer Prev 16(3): 1063-1067.

585. Ye M, Du K, Zhou J, Zhou Q, Shou M, et al. (2018) A meta-analysis of the efficacy of cognitive behavior therapy on quality of life and psychological health of breast cancer survivors and patients. Psychooncology 27(7): 1695-1703.

586. Kucherer S, Ferguson RJ (2017) Cognitive behavioral therapy for cancer-related cognitive dysfunction. Curr Opin Support Palliat Care 11(1): 46-51.

587. Qiu H, Ren W, Yang Y, Zhu X, Mao G, et al. (2018) Effects of cognitive behavioral therapy for depression on improving insomnia and quality of life in Chinese women with breast cancer: results of a randomized, controlled, multicenter trial. Neuropsychiatr Dis Treat 14: 2665-2673.

588. McCarthy MS, Matthews EE, Battaglia C, Meek PM (2018) Feasibility of a Telemedicine-Delivered Cognitive Behavioral Therapy for Insomnia in Rural Breast Cancer Survivors. Oncol Nurs Forum 45(5): 607-618.

589. Van de Wal M, Servaes P, Berry R, Thewes B, Prins J (2018) Cognitive Behavior Therapy for Fear of Cancer Recurrence: A Case Study. J Clin Psychol Med Settings 25(4): 390-407.

590. Daniels S (2015) Cognitive Behavior Therapy for Patients with Cancer. J Adv Pract Oncol 6(1): 54-56.

591. Yi JC, Syrjala KL (2017) Anxiety and Depression in Cancer Survivors. Med Clin North Am 101(6): 10991113.

592. Silva NM, Santos MAD, Rosado SR, Galvão CM, Sonobe HM (2017) Psychological aspects of patients with intestinal stoma: integrative review. Rev Lat Am Enfermagem 25: e2950.

593. Mosher CE, Winger JG, Given BA, Shahda S, Helft PR (2017) A systematic review of psychosocial 


\section{Advances in Pharmacology and Clinical Trials}

interventions for colorectal cancer patients. Support Care Cancer 25(7): 2349-2362.

594. Sandler CX, Goldstein D, Horsfield S, Bennett BK, Friedlander M, et al. (2017) Randomized Evaluation of Cognitive-Behavioral Therapy and Graded Exercise Therapy for Post-Cancer Fatigue. J Pain Symptom Manage 54(1): 74-84.

595. Arch JJ, Mitchell JL, Genung SR, Fisher R, Andorsky DJ, et al. (2019) randomized controlled trial of a group acceptance-based intervention for cancer survivors experiencing anxiety at re-entry ('Valued Living'): study protocol. BMC Cancer 19(1): 89.

596. Zhu G, Zhang X, Wang Y, Xiong H, Zhao Y, et al. (2016) Effects of exercise intervention in breast cancer survivors: a meta-analysis of 33 randomized controlled trails. Onco Targets Ther 9: 2153-2168.

597. Okuyama S, Jones W, Ricklefs C, Tran ZV (2015) Psychosocial telephone interventions for patients with cancer and survivors: a systematic review. Psychooncology 24(8): 857-870.

598. Dong B, Xie C, Jing X, Lin L, Tian L (2019) Yoga has a solid effect on cancer-related fatigue in patients with breast cancer: a meta-analysis. Breast Cancer Res Treat 177(1): 5-16.

599. El-Hashimi D, Gorey KM (2019) Yoga-Specific Enhancement of Quality of Life among Women With Breast Cancer: Systematic Review and Exploratory Meta-Analysis of Randomized Controlled Trials. J Evid Based Integr Med 24: 2515690X19828325.

600. Wei CW, Wu YC, Chen PY, Chen PE, Chi CC, et al. (2019) Effectiveness of Yoga Interventions in Breast Cancer-Related lymphedema: A systematic review. Complement Ther Clin Pract 36: 49-55.

601. Sohl SJ, Danhauer SC, Birdee GS, Nicklas BJ, Yacoub G, et al. (2016) A brief yoga intervention implemented during chemotherapy: A randomized controlled pilot study. Complement Ther Med pp: 139-142.

602. Cramer H, Pokhrel B, Fester C, Meier B, Gass F, et al. (2016) A randomized controlled bicenter trial of yoga for patients with colorectal cancer. Psychooncology 25(4): 412-420.

603. Durrani S, Contreras J, Mallaiah S, Cohen L, Milbury $\mathrm{K}$ (2019) The Effects of Yoga in Helping Cancer Patients and Caregivers Manage the Stress of a
Natural Disaster: A Brief Report on Hurricane Harvey. Integr Cancer Ther 18: 1534735419866923.

604. Zhang X, Wang X, Zhang B, Yang S, Liu D (2019) Effects of acupuncture on breast cancer-related lymphoedema: a systematic review and meta-analysis of randomised controlled trials. Acupunct Med 37(1): 16-24.

605. Bao T, Iris Zhi W, Vertosick EA, Li QS, DeRito J, et al. (2018) Acupuncture for breast cancer-related lymphedema: a randomized controlled trial. Breast Cancer Res Treat 170(1): 77-87.

606. Zhu H, Li J, Peng Z, Huang Y, Lv X, et al. (2017) Effectiveness of acupuncture for breast cancer related lymphedema: protocol for a single-blind, shamcontrolled, randomized, multicenter trial. BMC Complement Altern Med 17(1): 467.

607. Pan Y, Yang K, Shi X, Liang H, Shen X, et al. (2018) Clinical Benefits of Acupuncture for the Reduction of Hormone Therapy-Related Side Effects in Breast Cancer Patients: A Systematic Review. Integr Cancer Ther 17(3): 602-618.

608. Hasenoehrl T, Keilani M, Palma S, Crevenna R (2019) Resistance exercise and breast cancer related lymphedema - a systematic review update. Disabil Rehabil 13: 1-10.

609. Duyur Cakıt B, Pervane Vural S, Ayhan FF (2019) Complex Decongestive Therapy in Breast CancerRelated Lymphedema: Does Obesity Affect the Outcome Negatively? Lymphat Res Biol 17(1): 45-50.

610. Jeffs E, Ream E, Taylor C, Bick D (2018) Clinical effectiveness of decongestive treatments on excess arm volume and patient-centered outcomes in women with early breast cancer-related arm lymphedema: a systematic review. JBI Database System Rev Implement Rep 16(2): 453-506.

611. Myers JS, Mitchell M, Krigel S, Steinhoff A, BoyceWhite A, et al. (2018) Qigong intervention for breast cancer survivors with complaints of decreased cognitive function. Support Care Cancer 27(4): 13951403.

612. Cifu G, Power MC, Shomstein S, Arem H (2018) Mindfulness-based interventions and cognitive function among breast cancer survivors: a systematic review. BMC Cancer 18(1): 1163. 


\section{Advances in Pharmacology and Clinical Trials}

613. Smith L, Gordon D, Scruton A, Yang L (2016) The potential yield of Tai Chi in cancer survivorship. Future Sci OA 2(4): FSO152.

614. Dennis DL, Waring JL, Payeur N, Cosby C, Daudt HM (2013) Making lifestyle changes after colorectal cancer: insights for program development. Curr Oncol 20(6): e493-511.

615. Fong SS, Ng SS, Luk WS, Chung JW, Chung LM, et al. (2013) Shoulder Mobility, Muscular Strength, and Quality of Life in Breast Cancer Survivors with and without Tai Chi Qigong Training. Evid Based Complement Alternat Med 2013: 787169.

616. Shin ES, Seo KH, Lee SH, Jang JE, Jung YM, et al. (2016) Massage with or without aromatherapy for symptom relief in people with cancer. Cochrane Database Syst Rev 6: CD009873.

617. Imanishi J, Kuriyama H, Shigemori I, Watanabe S, Aihara Y, et al. (2007) Anxiolytic effect of aromatherapy massage in patients with breast cancer. Evid Based Complement Alternat Med 6(1): 123-128.

618. Fiorelli A, Morgillo F, Milione R, Pace MC, Passavanti MB, et al. (2012) Control of post-thoracotomy pain by transcutaneous electrical nerve stimulation: effect on serum cytokine levels, visual analogue scale, pulmonary function and medication. Eur J Cardiothorac Surg 41(4): 861-868.

619. Chubak J, Hawkes R (2016) Animal-Assisted Activities: Results from a Survey of Top-Ranked Pediatric Oncology Hospitals. J Pediatr Oncol Nurs 33(4): 289-296.

620. Vahed N, Kabiri N, Oskouei MM, Gavgani VZ, Khatooni AA, et al. (2017) The Effect of Music in Operating Room: A Systematic Review. BMJ Open 7(1): A1-A75.

621. Chubak J (2017) Therapy-dog visits for kids with cancer: A safe way to induce smiles? Web Kaiser Permanente Washington Health Research Institute. 